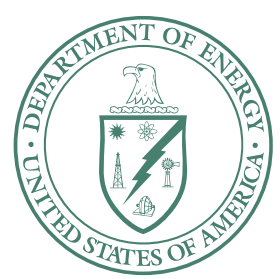

U.S. Department of Energy

Idaho Operations Office

\title{
Remedial Design/Remedial Action Work Plan for Operable Units 6-05 and 10-04, Phase IV
}

November 2006 
DOE/ID-11261

Revision 0

Project No. 23368

\section{Remedial Design/Remedial Action Work Plan for Operable Units 6-05 and 10-04, Phase IV}

November 2006

Prepared for the 



\section{ABSTRACT}

The remedial design/remedial action for Operable Unit 6-05 (Waste Area Group 6) and Operable Unit 10-04 (Waste Area Group 10) — collectively called Operable Unit 10-04 - has been divided into four phases. Phase I consists of developing and implementing institutional controls at Operable Unit 10-04 sites and developing and implementing Idaho National Laboratory-wide plans for both institutional controls and ecological monitoring. Phase II will remediate sites contaminated with trinitrotoluene and Royal Demolition Explosive. Phase III will remediate lead contamination at a gun range, and Phase IV will remediate hazards from unexploded ordnance (UXO).

This Phase IV Remedial Design/Remedial Action Work Plan addresses the remediation of areas with the potential for UXO at the Idaho National Laboratory. These areas include portions of the Naval Proving Ground, the Arco High-Altitude Bombing Range, and the Twin Buttes Bombing Range. Five areas within the Naval Proving Ground that are known to contain UXO include the Naval Ordnance Disposal Area, the Mass Detonation Area, the Experimental Field Station, the Rail Car Explosion Area, and the Land Mine Fuze Burn Area. The Phase IV remedial action will be concentrated in these five areas. For other areas, such as the Arco High-Altitude Bombing Range and the Twin Buttes Bombing Range, ordnance has largely consisted of sand-filled practice bombs that do not pose an explosion risk. Ordnance encountered in these areas will be addressed under the Phase I Operations and Maintenance Plan that allows for the recovery and disposal of ordnance that poses an imminent risk to human health or the environment.

Based upon consideration of the requirements of the Comprehensive Environmental Response, Compensation, and Liability Act; the detailed analysis of alternatives; and public comments, the Agencies have selected Alternative 3 (UXO detection, removal, and institutional controls) as the selected remedy for UXO-contaminated sites to mitigate potential human health risk from inadvertent contact to UXO. Performance standards were implemented as design criteria for each site to ensure that the selected remedy protects human health and the environment.

Following the removal and disposal of ordnance by high-order detonation, the Mass Detonation Area will be sampled to determine the extent, if any, of soil contamination that may have occurred as a result of detonation activities associated with the disposal of ordnance during the Phase II and Phase IV activities, respectively. If contaminant concentrations in the soil at the Mass Detonation Area exceed risk-based levels, the soil will be remediated in accordance with the requirements delineated herein. Remediation of the contaminated soil at the Mass Detonation Area will include sampling and analysis of soil to determine excavation requirements and to determine when the remediation goals have been achieved, excavating contaminated soil, backfilling and contouring excavated areas, revegetating affected areas, and monitoring air and soil during the remedial action. 


\section{CONTENTS}

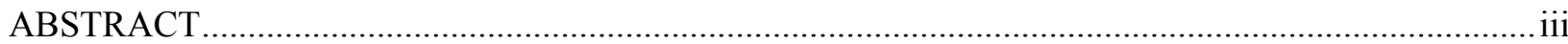

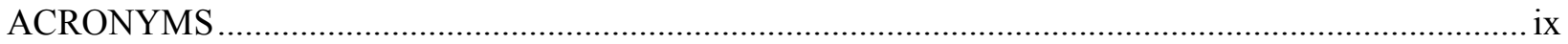

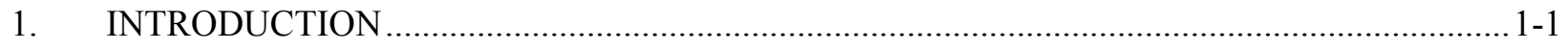

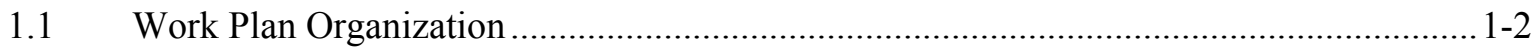

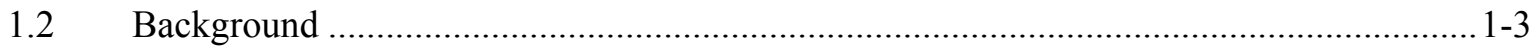

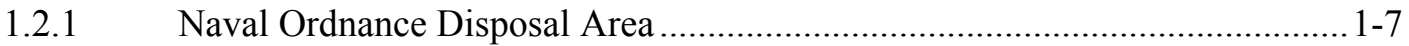

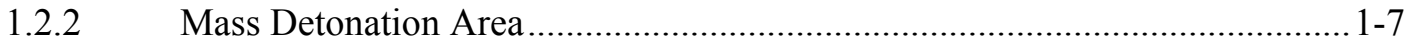

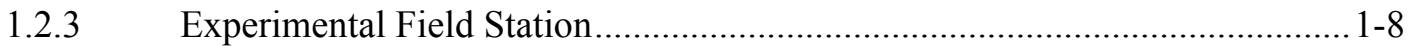

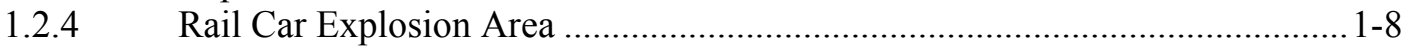

1.2.5 Land Mine Fuze Burn Area.................................................................... 1-8

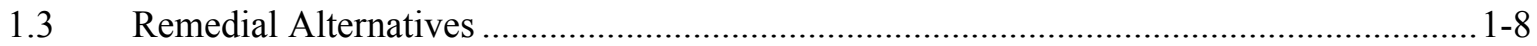

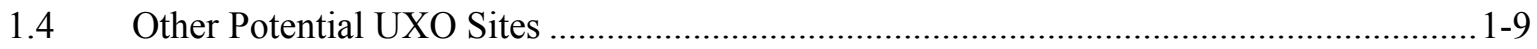

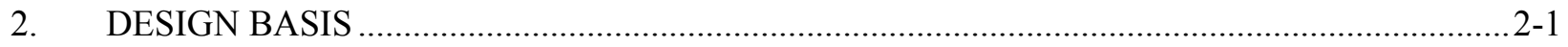

2.1 General Description of Project Components …............................................................ 2-1

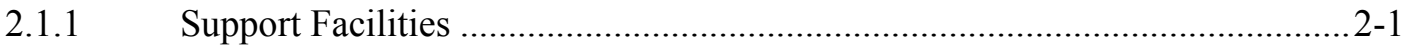

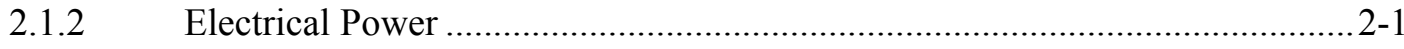

2.1.3 Project Execution Services...................................................................... $2-1$

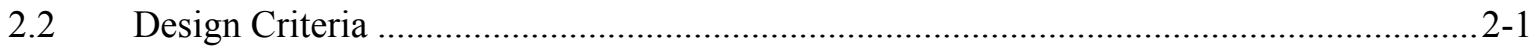

2.2.1 Management Control Procedures …..........................................................2-2

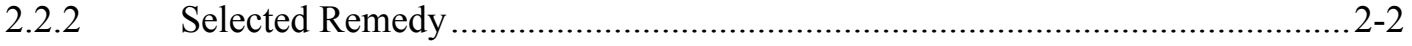

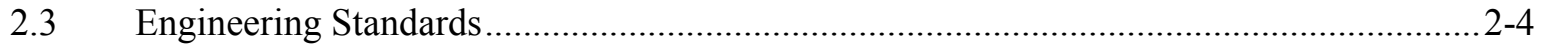

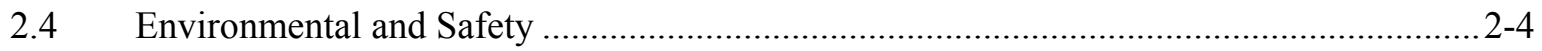

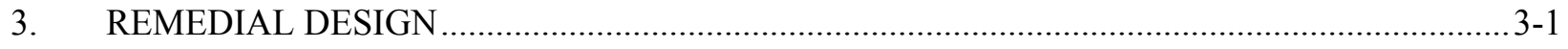

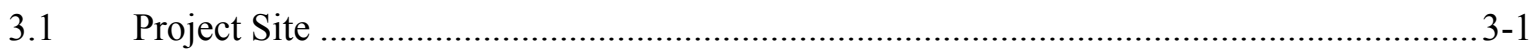

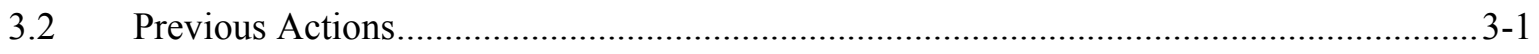

3.2.1 Operable Unit 10-05 Interim Action ...................................................... 3-1

3.2.2 1994 Non-Time-Critical Removal Action.................................................. 3-2

3.2.3 1996 Time-Critical Removal Action..................................................... 3-3

3.2.4 1997 Non-Time-Critical Removal Action.........................................................3-4

3.2.5 2004 Time-Critical Removal Action............................................................ 3-4 


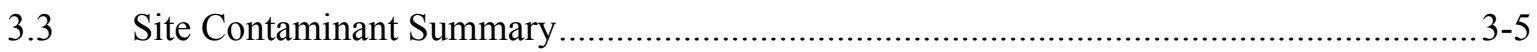

3.3.1 Naval Ordnance Disposal Area ........................................................... 3-5

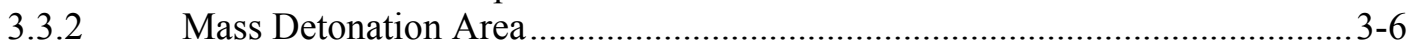

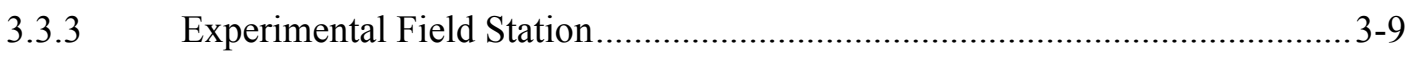

3.3.4 Rail Car Explosion Area ..........................................................................

3.3.5 Land Mine Fuze Burn Area............................................................................ 3-11

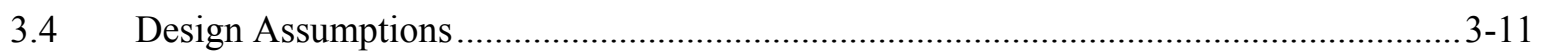

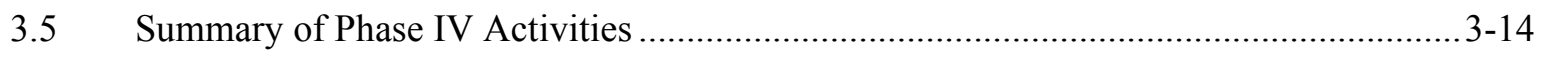

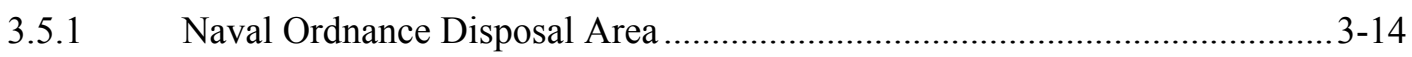

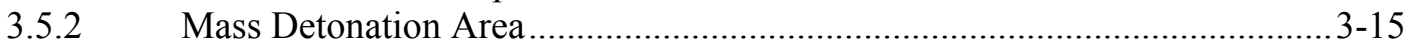

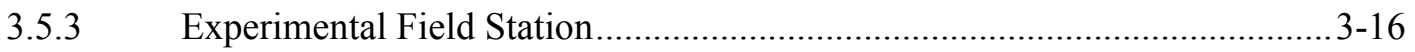

3.5.4 Rail Car Explosion Area ..................................................................

3.5.5 Land Mine Fuze Burn Area............................................................. 3-17

4. HUMAN HEALTH AND ENVIRONMENTAL COMPLIANCE .............................................4-1

4.1 Remedial Action Objectives ............................................................................... $4-1$

4.1.1 Unexploded Ordnance Contaminated Sites.............................................. 4-1

Explosive-Contaminated Soil................................................................... 4-1

4.2 Applicable or Relevant and Appropriate Requirements ............................................... 4-3

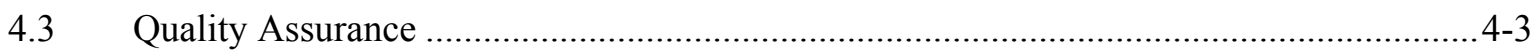

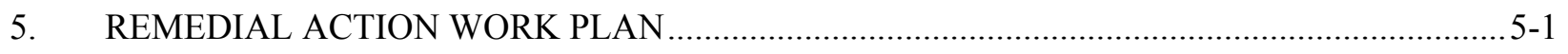

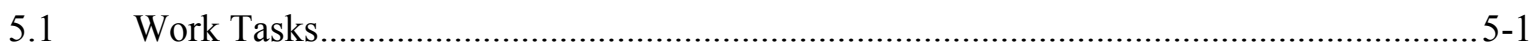

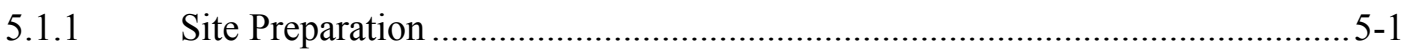

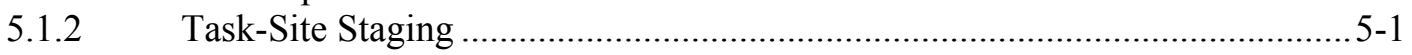

5.1.3 Premobilization ........................................................................... $5-1$

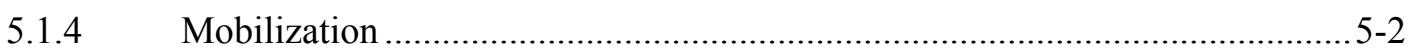

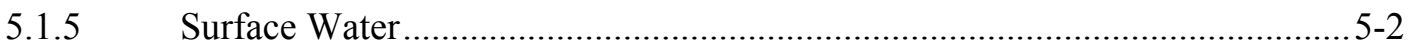

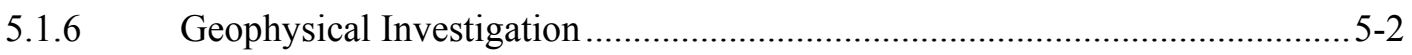

5.1.7 Recovery and Disposal of Unexploded Ordnance ....................................... 5-3

5.1.8 Recovery and Disposal of Explosive Fragments.......................................... 5-3

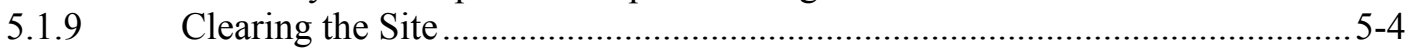

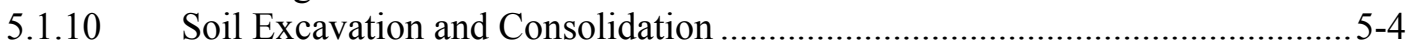

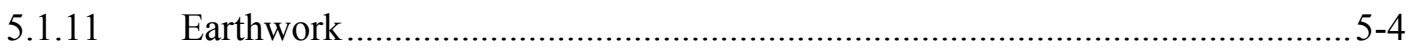

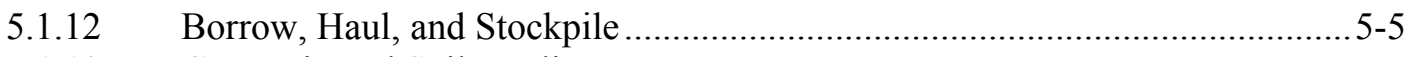

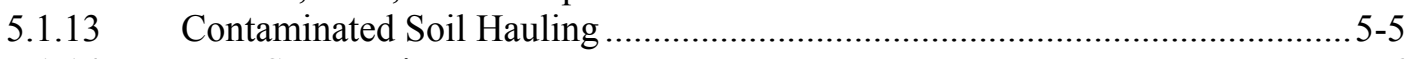

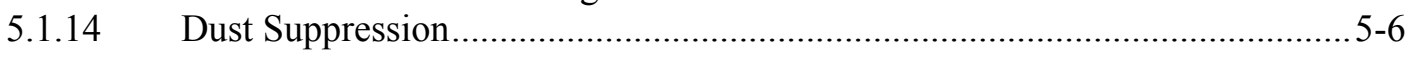

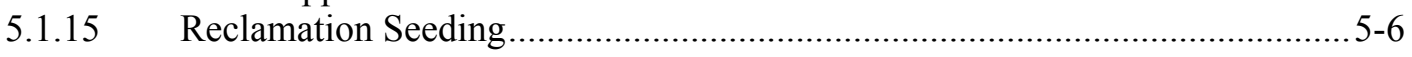

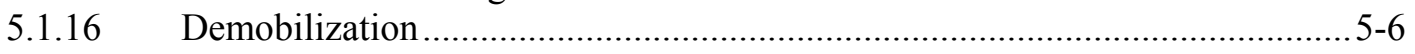




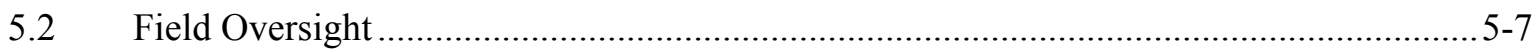

5.2.1 Protocol and Coordination of Field Oversight .......................................... 5-7

$5.3 \quad$ Project Cost Estimate ............................................................................................

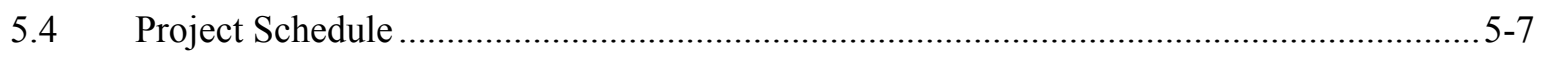

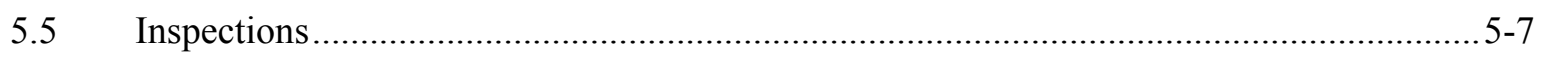

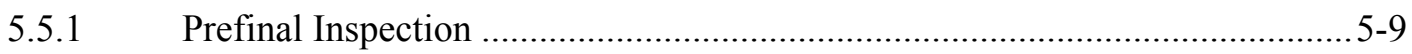

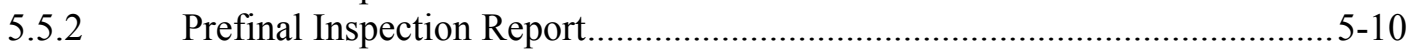

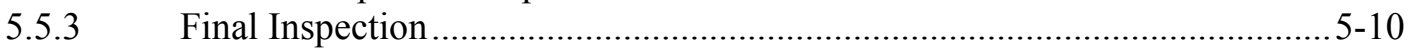

5.6 Remedial Action Sampling and Analysis Plan ........................................................ 5-10

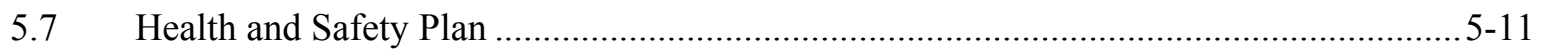

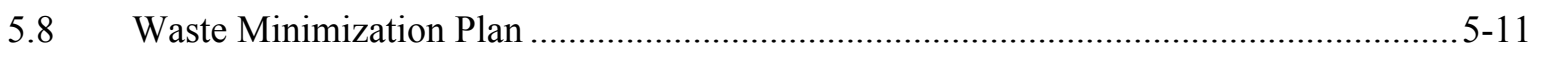

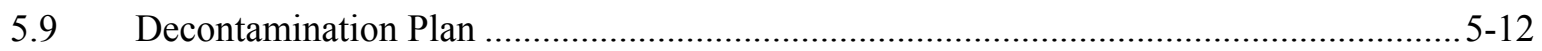

5.10 Spill Prevention/Response Program ............................................................................ 5-12

5.11 Operations and Maintenance Plan .......................................................................... $5-12$

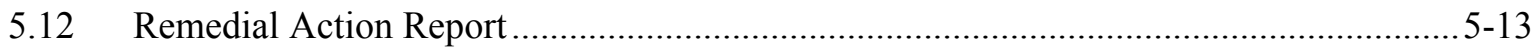

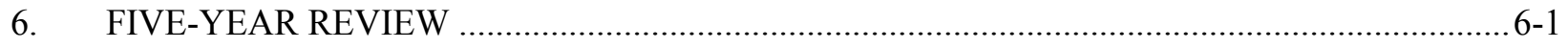

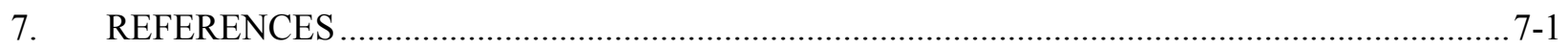

Appendix A-Air Emissions Analysis for Detonation of Unexploded Ordnance, Waste

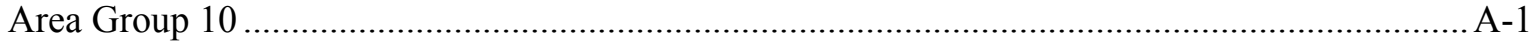

Appendix B —Waste Management Plan ............................................................................................... B-1

Appendix C-Operations and Maintenance Plan for Operable Units 6-05 and 10-04, Phase IV ........... C-1

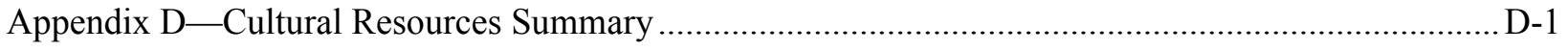




\section{FIGURES}

1-1. Map of the Idaho National Laboratory Site showing the locations of major facilities................... 1-4

1-2. Location of Waste Area Group 10 Comprehensive Environmental Response, Compensation, and Liability Act sites at the Idaho National Laboratory Site .................................................... 1-5

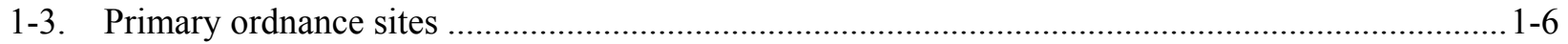

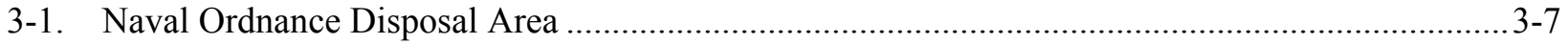

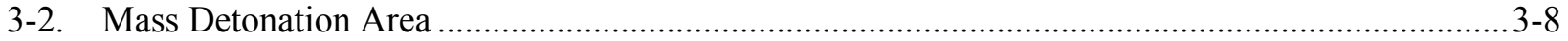

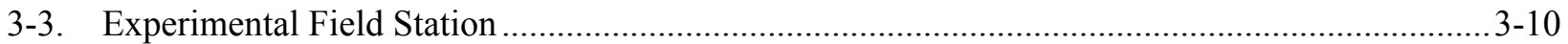

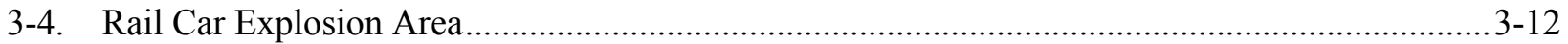

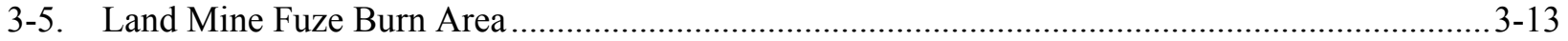

TABLES

4-1. Remediation goals for Operable Unit 10-04 contaminated soil

4-2. Compliance with applicable or relevant and appropriate requirements and to-be-considered guidance for the Phase IV remedial action ................................................................................. $4-4$

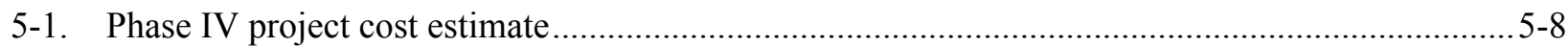

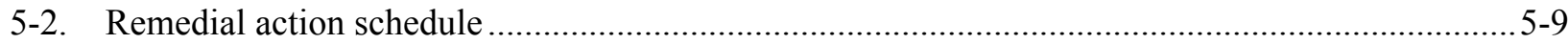




\section{ACRONYMS}

ARAR applicable or relevant and appropriate requirement

CERCLA Comprehensive Environmental Response, Compensation, and Liability Act

CFA Central Facilities Area

CFR Code of Federal Regulations

CRM cultural resource management

DEQ (Idaho) Department of Environmental Quality

DOE Department of Energy

DOE-ID Department of Energy Idaho Operations Office

DOD Department of Defense

EOD explosive ordnance disposal

EPA Environmental Protection Agency

HAD hazard assessment document

HASP health and safety plan

ICDF Idaho CERCLA Disposal Facility

ICP Idaho Cleanup Project

IDAPA Idaho Administrative Procedures Act

INL Idaho National Laboratory

INTEC Idaho Nuclear Technology and Engineering Center

IWTS Integrated Waste Tracking System

MCP management control procedure

MDA Mass Detonation Area

NCP National Contingency Plan (also known as the National Oil and Hazardous Substances Pollution Contingency Plan)

NOAA National Oceanic and Atmospheric Administration

NODA Naval Ordnance Disposal Area

NPG Naval Proving Ground 


$\begin{array}{ll}\text { NRF } & \text { Naval Reactors Facility } \\ \text { O\&M } & \text { operations and maintenance } \\ \text { OU } & \text { operable unit } \\ \text { PDD } & \text { program description document } \\ \text { PLN } & \text { plan } \\ \text { PPE } & \text { personal protective equipment } \\ \text { QA/QC } & \text { quality assurance/quality control } \\ \text { RAO } & \text { remedial action objective } \\ \text { RCRA } & \text { Resource Conservation and Recovery Act } \\ \text { RD/RA } & \text { remedial design/remedial action } \\ \text { RDX } & \text { Royal Demolition Explosive } \\ \text { RI/FS } & \text { remedial investigation/feasibility study } \\ \text { ROD } & \text { Record of Decision } \\ \text { RTC } & \text { Reactor Technology Complex } \\ \text { STF } & \text { Security Training Facility } \\ \text { TNT } & \text { trinitrotoluene } \\ \text { USC } & \text { United States Code } \\ \text { UXO } & \text { unexploded ordnance } \\ \text { WAG } & \text { waste area group } \\ \text { R } & \end{array}$




\section{Remedial Design/Remedial Action Work Plan for Operable Units 6-05 and 10-04, Phase IV}

\section{INTRODUCTION}

In accordance with the Federal Facility Agreement and Consent Order for the Idaho National Engineering Laboratory (DOE-ID 1991) among the Department of Energy Idaho Operations Office (DOE-ID), the U.S. Environmental Protection Agency (EPA), and the Idaho Department of Environmental Quality (DEQ) - the DOE-ID, EPA, and DEQ are hereafter referred to as the Agencies-DOE-ID submits this Remedial Design/Remedial Action (RD/RA) Work Plan for Operable Unit (OU) 10-04. Under the current remediation management strategy outlined in the Federal Facility Agreement and Consent Order for the Idaho National Engineering Laboratory (DOE-ID 1991), the location identified for the remedial action - hereafter referred to as OU 10-04 - is designated as Waste Area Group (WAG) 6, OU 6-05, Experimental Breeder Reactor-I/Boiling Water Reactor Experiment Area and WAG 10, OU 10-04 Miscellaneous Sites at the Idaho National Laboratory (INL). In addition, WAG 10 includes OU 10-08, which was added to address INL-wide groundwater issues and new sites that are passed by other groups to WAG 10 . DOE-ID will prepare a separate OU 10-08 comprehensive remedial investigation/feasibility study (RI/FS) and Record of Decision (ROD). Therefore, OU 10-04 will not address INL-wide groundwater issues or potential new sites.

As required by the Comprehensive Environmental Response, Compensation, and Liability Act (CERCLA) (42 United States Code [USC] § 9601 et seq.), the OU 10-04 remedial action will proceed in accordance with the Record of Decision Experimental Breeder Reactor-I/Boiling Water Reactor Experiment Area and Miscellaneous Sites, Operable Units 6-05 and 10-04 (DOE-ID 2002). The OU 10-04 ROD (DOE-ID 2002) presents the selected remedies for 50 surface sites evaluated under the Comprehensive Remedial Investigation/Feasibility Study for Waste Area Groups 6 and 10 Operable Unit 10-04 (DOE-ID 2001).

The remedial action for OU 10-04 is divided into four phases. Phase I consists of developing and implementing institutional controls at OU 10-04 sites and developing and implementing INL-wide plans for both institutional controls and ecological monitoring. Phase II will remediate sites contaminated with trinitrotoluene (TNT) and Royal Demolition Explosive (RDX). Phase III will remediate lead contamination at a gun range, and Phase IV will remediate hazards associated with unexploded ordnance (UXO). Separate RD/RA work plans will be submitted for each remediation phase. The scope and schedule for implementing these remediation phases are presented in Operable Units 6-05 and 10-04, Experimental Breeder Reactor-I/Boiling Water Reactor Experiment Area and Miscellaneous Sites, Remedial Design/Remedial Action Scope of Work (DOE-ID 2003).

During the 1940s, much of the area now designated as the INL was used by the military for testing long Navy guns and for bombing practice. Most of the ordnance, UXO, and ordnance-related areas at the INL result from ordnance testing, demolition of explosives, and bombing practice and are located within the contiguous area of the Naval Proving Ground (NPG). Phase IV activities will require the removal and destruction of UXO found primarily on five sites within the INL. The UXO will be disposed of by high-order detonation at the Mass Detonation Area (MDA), except in the case that the UXO cannot be safely recovered and transported to the MDA for disposal. In those cases, the UXO will be disposed of by high-order detonation in place. The MDA will be assessed for explosives contamination following the completion of all other Phase IV remediation activities to determine the impact of disposal activities on those areas. Any other non-MDA locations where UXO had to be disposed of in place will be assessed for explosives contamination immediately following in-place detonation. If the assessment demonstrates 
that contamination levels exceed the remediation goals specified in the OU 10-04 ROD (DOE-ID 2002), the contaminated soils will be remediated in accordance with the requirements delineated therein. The five sites located inside the NPG known to contain UXO include the following:

- $\quad$ Naval Ordnance Disposal Area (NODA)

- $\quad$ MDA

- $\quad$ Experimental Field Station

- $\quad$ Rail Car Explosion Area

- $\quad$ Land Mine Fuze Burn Area.

Based upon consideration of the requirements of CERCLA, the detailed analysis of alternatives, and public comments, the Agencies have selected Alternative 3 (UXO detection, removal, and institutional controls) as the selected remedy for UXO-contaminated sites to mitigate potential human health risk from inadvertent contact to UXO. Performance standards were implemented as design criteria for each site to ensure that the selected remedy protects human health and the environment.

\subsection{Work Plan Organization}

The RD/RA for OUs 6-05 and 10-04 is divided into the following four phases:

- $\quad$ Phase I —institutional controls and ecological monitoring

- $\quad$ Phase II-remediation of TNT- and RDX-contaminated sites

- $\quad$ Phase III-remediation of the Security Training Facility (STF) -02 Gun Range

- $\quad$ Phase IV—remediation of ordnance-contaminated sites.

This RD/RA Work Plan outlines the major activities to be implemented in performing the Phase IV activities for OU 10-04 in accordance with the OU 10-04 ROD (DOE-ID 2002). In addition, this RD/RA Work Plan describes the sites, contaminants, project management, tasks, schedules, and cost estimates. The following are brief descriptions of the RD/RA Work Plan's sections and appendixes:

- $\quad$ Section 1 describes the background and history of WAGs 6 and 10 and provides an overview of the selected remedy for the area of concern.

- $\quad$ Section 2 provides the design criteria, including the design codes and standards, and assumptions.

- $\quad$ Section 3 discusses the project's remedial design. A summary of the required activities is presented.

- $\quad$ Section 4 provides the initial evaluation of the UXO-contaminated sites, including an evaluation of the potential risks to human health and the environment. In addition, the remedial action objectives (RAOs) and applicable or relevant and appropriate requirements (ARARs) are identified, and the quality assurance requirements are discussed.

- Section 5 outlines the OU 6-05 and 10-04 remedial action work plan. This section includes the necessary steps and documentation required to complete the remedial action for the UXO-contaminated sites, as described in Sections 1-4. The required work tasks, project cost estimates, inspections, environmental and safety plans, and sampling and analysis plans are discussed in this section. 
- $\quad$ Section 6 describes the necessary actions involved for each 5-year review to occur after the remedial action has taken place. The sites will be included in any Sitewide 5-year reviews performed prior to finalization of the Phase IV remedial action report.

- $\quad$ Section 7 lists the reference material.

- $\quad$ Appendix A presents a summary of the air emissions modeling to satisfy project ARARs.

- $\quad$ Appendix B describes the management and disposal of waste generated during Phase IV activities.

- $\quad$ Appendix C provides the Operations and Maintenance (O\&M) Plan for OU 10-04 Phase IV.

- $\quad$ Appendix D presents the cultural resources summary.

In addition, three separate documents are associated with this RD/RA Work Plan:

- $\quad$ The Field Sampling Plan for the Operable Units 6-05 and 10-04 Remedial Action, Phase IV (DOE-ID 2006a) describes the sampling and analyses required during Phase IV activities.

- $\quad$ The Quality Assurance Project Plan for Waste Area Groups 1, 2, 3, 4, 5, 6, 7, 10, and Removal Actions (DOE-ID 2006b) describes the necessary steps required to ensure project data quality.

- The "Miscellaneous Sites Cleanup Project Health and Safety Plan" (PLN-2128) describes the possible hazards and the required steps to protect the health and safety of project workers.

\subsection{Background}

Located $51 \mathrm{~km}(32 \mathrm{mi})$ west of Idaho Falls, Idaho, the INL is a government-owned, contractor-operated facility managed by DOE-ID (Figure 1-1). Occupying $2,305 \mathrm{~km}^{2}\left(890 \mathrm{mi}^{2}\right)$ of the northeastern portion of the eastern Snake River Plain, the INL Site encompasses portions of five Idaho counties: (1) Butte, (2) Jefferson, (3) Bonneville, (4) Clark, and (5) Bingham. As shown in Figure 1-2, WAG 10 is comprised of miscellaneous surface sites and liquid disposal areas throughout the INL that are not included within other WAGs (WAGs 1-9).

In 1942, the U.S. Navy acquired the acreage known as the NPG to test fire 3- to 16-in.-diameter naval ship guns reconditioned at the Naval Ordnance Plant in Pocatello, Idaho. Between 1942 and 1950, approximately 1,650 minor (3- to 5-in.) and major (16-in.) guns were tested. Although a small number of live and armed projectiles were fired from the big guns at close range into stacks of bombs, all the projectiles found to date with lands and groove gouges in the rotating bands have been target projectiles that do not contain main explosive charges. In 1949, the area was established as the National Reactor Testing Station and has remained a reservation that is devoted to energy research and environmental-related activities ever since.

A detailed summary of the previous investigations and remediation activities at the ordnance sites is presented in the OU 10-04 Comprehensive RI/FS (DOE-ID 2001). As discussed in Section 8.2 of the Record of Decision Experimental Breeder Reactor-I/Boiling Water Reactor Experiment Area and Miscellaneous Sites, Operable Units 6-05 and 10-04 (DOE-ID 2002), five sites within the NPG have confirmed UXO (see Figure 1-3), as summarized in Sections 1.2.1 through 1.2.5. Therefore, the remediation activities associated with Phase IV will be concentrated in these areas. If ordnance that poses an imminent risk to human health or the environment is encountered elsewhere on the INL, it will be removed and disposed of in accordance with the requirements outlined in the Operations and Maintenance Plan for Operable Units 6-05 and 10-04, Phase I (DOE-ID 2004). 


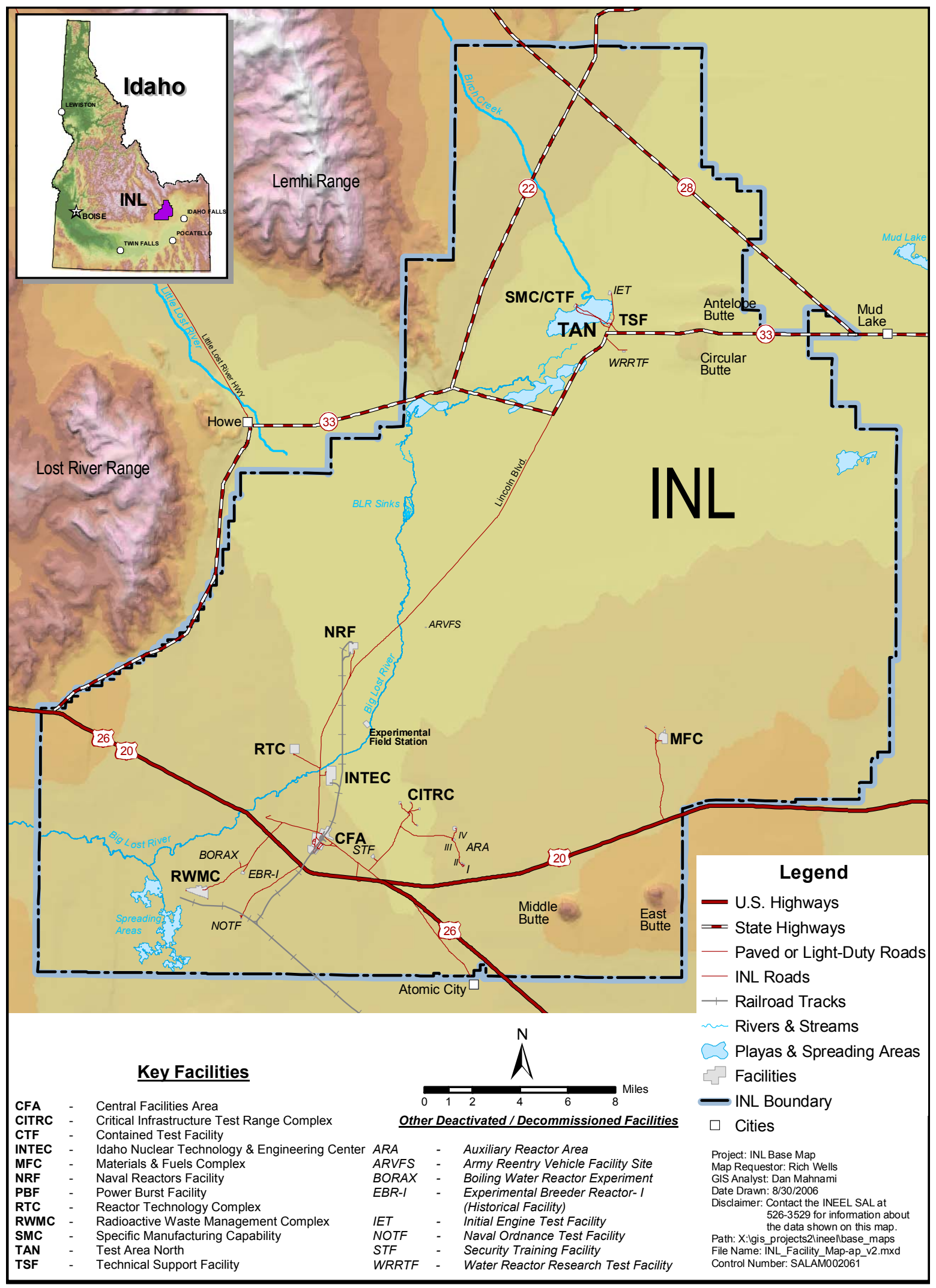

Figure 1-1. Map of the Idaho National Laboratory Site showing the locations of major facilities. 


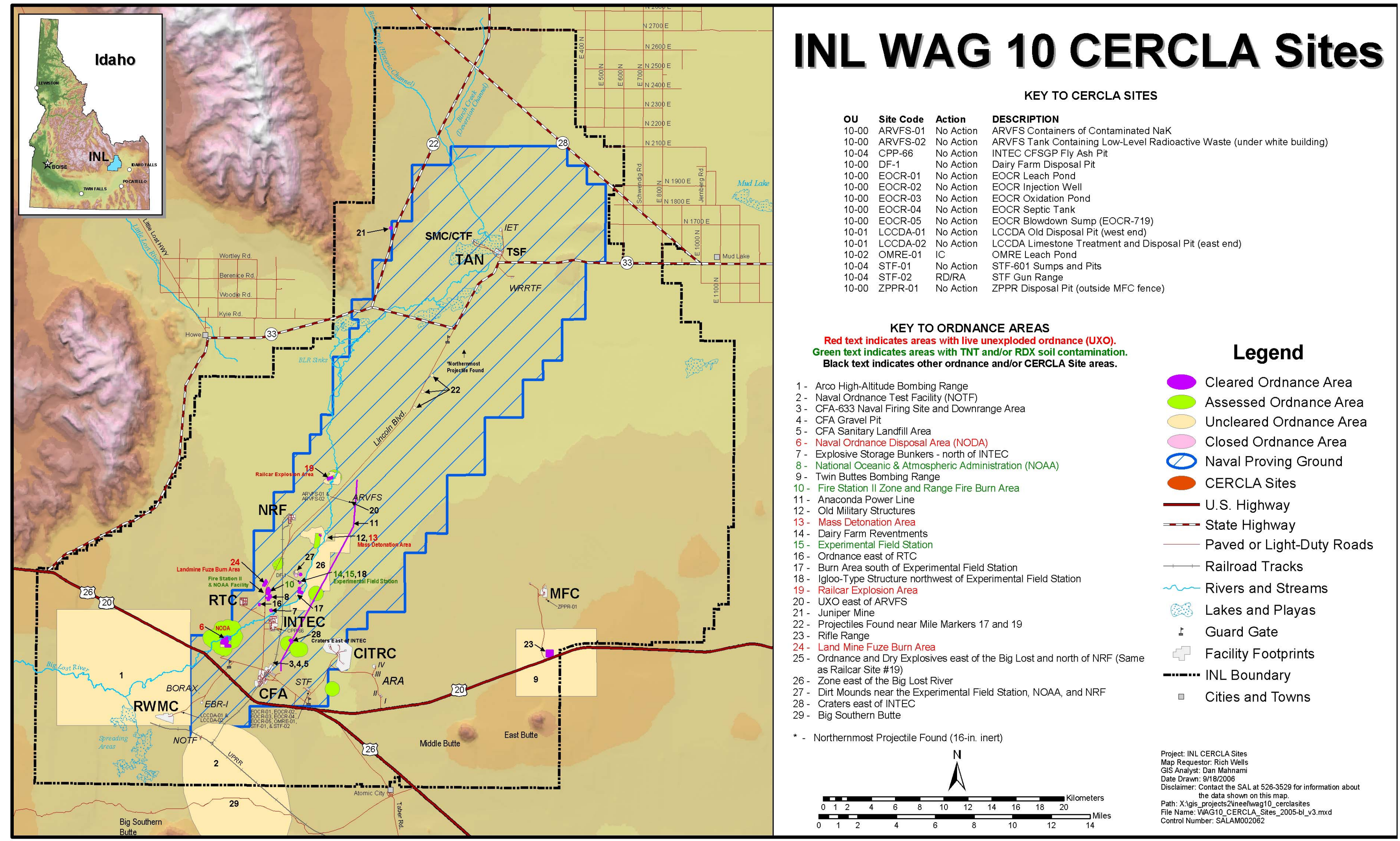

Figure 1-2. Location of Waste Area Group 10 Comprehensive Environmental Response, Compensation, and Liability Act sites at the Idaho National Laboratory Site. 


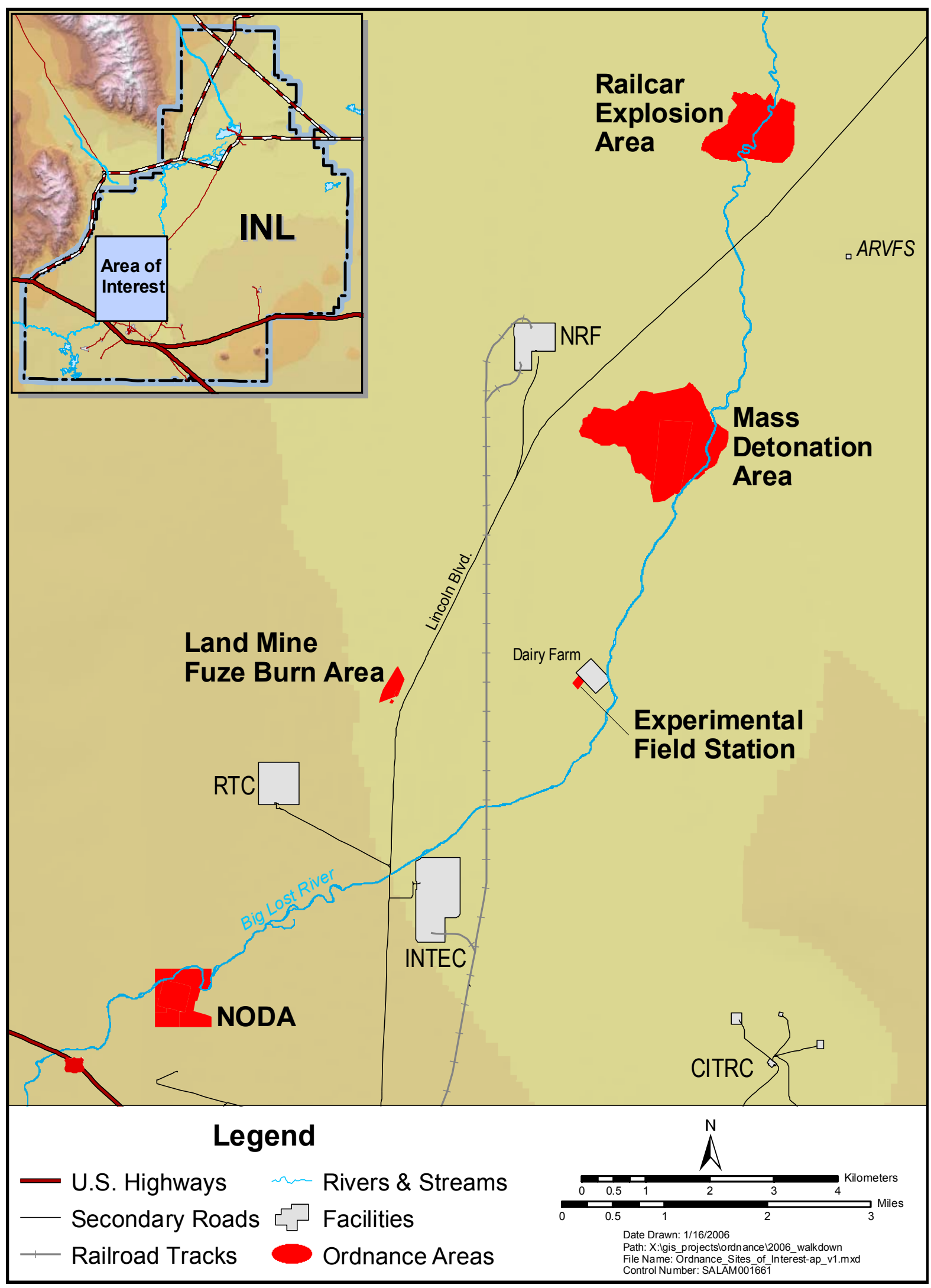

Figure 1-3. Primary ordnance sites. 


\subsubsection{Naval Ordnance Disposal Area}

The NODA site is located approximately $1.3 \mathrm{~km}(0.8 \mathrm{mi})$ northeast of U.S. Highway $20 / 26$ between Mile Markers 265 and 266 and about $2.7 \mathrm{~km}(1.7 \mathrm{mi})$ southwest of the Reactor Technology Complex (RTC) (formerly the Test Reactor Area) at the INL, as shown in Figure 1-3. The NODA was reportedly used by the U.S. Navy as an ordnance and nonradioactive hazardous material disposal area during the 1940s. Following the establishment of the National Reactor Testing Station in 1949 (now the INL), the NODA came under control of the U.S. Atomic Energy Commission (now U.S. Department of Energy [DOE]). From about 1967 to 1985, approximately 3,175 kg (7,000 lb) of reactive material was treated (burned) at the NODA. Most of the reactive materials consisted of finely divided zirconium, hafnium, and zircaloy, which were openly burned and treated in disposal pits located at the NODA. No known disposal of radioactive materials occurred at the NODA and no evidence exists as to the contrary. Between 1967 and 1985, the NODA also was used as a storage area for hazardous waste generated at INL. Solvents, corrosives, ignitable materials, heavy-metal-contaminated solutions, formaldehyde, polychlorinated biphenyl materials, waste laboratory chemicals, and reactive materials were stored at this site until 1982. By October 1985, all these materials had been removed for off-Site disposal as hazardous waste or treated on-Site by open burning, as allowed by Resource Conservation and Recovery Act (RCRA) regulations (42 USC $§ 6901$ et seq.; DOE-ID 1998).

In 1985, the NODA was added to the RCRA, Part A, permit application as a thermal treatment unit. The last treatment of hazardous waste occurred in 1988 (except for one emergency action/detonation in 1990). Since 1988, activities necessary to formally close the NODA were initiated. These activities included soil sampling and analysis, removal of contaminated soil, emergency removal of ordnance, maintenance of access signs and barricades, and preparation and submittal of all required documentation. In 1997, the DEQ terminated the Interim Status of the NODA with the agreement that the CERCLA Program would perform the final evaluation of the site in accordance with the Federal Facility Agreement and Consent Order for the Idaho National Engineering Laboratory (DOE-ID 1991).

The 1994 removal action included 16 ha (40 acres) centered approximately $762 \mathrm{~m}(2,500 \mathrm{ft})$ north of the current INL security force gun range on Portland Avenue (refer to Section 3.3.1, Figure 3-1) as well as 90 acres within the Twin Buttes Bombing Range (refer to Figure 1-2) and Naval Gun Shells located east of Lincoln Boulevard within the NPG (refer to Figure 1-2) (DOE-ID 2001). The action identified UXO and explosive residue chunks using visual and geophysical scans and either destroyed them in place or removed them. The items removed during the 1994 and 1997 removal actions included fuzes, ordnance, and scrap metal, supporting the potential for these to continue to be present. More detailed information about the NODA site can be found in the OU 10-04 Comprehensive RI/FS (DOE-ID 2001).

\subsubsection{Mass Detonation Area}

The MDA is located $0.6 \mathrm{~km}(0.4 \mathrm{mi})$ east of Mile Marker 8 on Lincoln Boulevard, north of the Idaho Nuclear Technology and Engineering Center (INTEC) and approximately $1.1 \mathrm{~km}(0.7 \mathrm{mi})$ southeast of the Naval Reactors Facility (NRF), as shown in Figure 1-3. The site encompasses 234.4 ha (579.1 acres) and has been used for a number of small- to large-scale sympathetic and mass detonation tests, with test shots ranging up to $226,800 \mathrm{~kg}(500,000 \mathrm{lb})$ of explosives. A sympathetic detonation test is a test performed to find out if a charge explodes when another charge is detonated next to it. The MDA site includes numerous blast craters varying in dimensions from a few feet to several tens of feet. Historically, large quantities of UXO, pieces of explosives, and structural debris scattered during past testing have been noted at the MDA. In addition, more recent disposal activities associated with previous removal actions, as well as explosive test activities, may have contributed to explosives contamination at 
the site. More detailed information pertaining to the MDA can be found in the OU 10-04 Comprehensive RI/FS (DOE-ID 2001).

\subsubsection{Experimental Field Station}

The Experimental Field Station includes multiple craters within which a variety of explosive tests were conducted. This site is located approximately $0.3 \mathrm{~km}(0.2 \mathrm{mi})$ west of the Big Lost River (see Figures 1-2 and 1-3). The site is an estimated 2 ha (5 acres) (DOE-ID 2001), although contamination resulting from UXO disposal is restricted to approximately $510 \mathrm{~m}^{2}\left(610 \mathrm{yd}^{2}\right)$ within the top $0.6 \mathrm{~m}(2 \mathrm{ft})$. The contamination does not pose human health risk above remediation goals but does pose a low ecological risk (DOE-ID 2002). The site is known to contain UXO, pieces of explosives, structural debris, and soil contamination. More detailed information about the Experimental Field Station can be found in the OU 10-04 Comprehensive RI/FS (DOE-ID 2001).

\subsubsection{Rail Car Explosion Area}

The Rail Car Explosion Area is located approximately $0.5 \mathrm{~km}(0.3 \mathrm{mi})$ due west of Mile Marker 12 on Lincoln Boulevard and adjacent to the Big Lost River, approximately $3.5 \mathrm{~km} \mathrm{(2.2} \mathrm{mi)} \mathrm{northeast} \mathrm{of}$ NRF, as shown in Figure 1-3. It encompasses approximately 115.7 ha (286 acres) and contains the debris scattered from a sympathetic detonation test involving five railroad cars, each loaded with $13,608 \mathrm{~kg}$ $(30,000 \mathrm{lb})$ of explosive ordnance for a total of $68,040 \mathrm{~kg}(150,000 \mathrm{lb})$. The ordnance included, but was not limited to, $500-\mathrm{kg}$ bombs loaded with Amatol and various Navy bombs loaded with TNT. The crater is located near the west bank of the Big Lost River, and pieces of ordnance and explosives (mostly RDX) have historically been located along both sides of the Big Lost River (DOE-ID 1998). The OU 10-04 Comprehensive RI/FS (DOE-ID 2001) provides additional information pertaining to the Rail Car Explosion Area.

\subsubsection{Land Mine Fuze Burn Area}

The Land Mine Fuze Burn Area is $125 \mathrm{~m}$ (410 ft) west of Lincoln Boulevard and approximately $0.24 \mathrm{~km}(0.15 \mathrm{mi})$ north of the Fire Station II training area (Mile Marker 5) (see Figure 1-3). The site consists of approximately five separate ordnance disposal locations in a 10.7-ha (26-acre) area between a meander of a former channel of the Big Lost River and an old abandoned irrigation canal that was hand-dug in the early 1900s (DOE-ID 2001). Based upon visual observation of the site, the UXO-contaminated area of the site is restricted to a few square meters in a single location (see Section 3.3.5, Figure 3-5). As described in the Preliminary Scoping Track 2 Summary Report for Operable Unit 10-03 Ordnance (DOE-ID 1998), the site was used by NPG personnel for disposal of land mine pressure plates and aerial bomb packaging materials and as an area to dispose of land mine fuzes by burning. Although previous removal actions were performed at the Land Mine Fuze Burn Area in 1996 and 1997, additional land mine fuzes are likely to be present. More detailed information about the Land Mine Fuze Burn Area can be found in the OU 10-04 Comprehensive RI/FS (DOE-ID 2001).

\subsection{Remedial Alternatives}

The remedial alternatives developed to address the ordnance areas included the following:

- $\quad$ Alternative 1: No action

- $\quad$ Alternative 2: Limited action and institutional controls

- $\quad$ Alternative 3: UXO detection with removal, and institutional controls. 
Based upon consideration of the requirements of CERCLA, the detailed analysis of alternatives, and public comments, the Agencies have selected Alternative 3 (UXO detection, removal, and institutional controls) as the selected remedy for UXO-contaminated sites to mitigate potential human health risk from inadvertent contact to UXO. Performance standards were implemented as design criteria for each site to ensure that the selected remedy protects human health and the environment.

\subsection{Other Potential UXO Sites}

Other areas exist at the INL with the potential for UXO, albeit relatively low based upon previous investigations. Previous removal actions conducted at the Arco High Altitude Bombing Range and the Twin Buttes Bombing Range resulted in the recovery and disposal of numerous practice bombs. Aside from these two sites, ordnance sites have been documented wherein a few pieces of ordnance have been encountered and have been removed. To address ordnance encountered in these areas, the Operations and Maintenance Plan for Operable Units 6-05 and 10-04, Phase I (DOE-ID 2004) provides for the recovery and disposal of ordnance and explosives that are encountered and pose an imminent risk to human health or the environment. 


\section{DESIGN BASIS}

\subsection{General Description of Project Components}

The project components (support facilities, electrical power, and project execution services) are described in the following subsections.

\subsubsection{Support Facilities}

The support facilities to be used during field operations include field office trailer(s), parking areas, and lay-down areas. A supply trailer(s) will be required for field use. Parking for personnel vehicles will be established at each task site with approval of the project office. Lay-down areas will be designated at each task site.

\subsubsection{Electrical Power}

Electrical power is not available at any of the five task sites. Therefore, if power is required for field operations, electrical generators must be provided.

\subsubsection{Project Execution Services}

The contractor will provide project execution services (e.g., ensuring that construction specifications are met and reviewing and improving construction interface documents) on an as-needed basis. In addition, engineering support will be provided during pre-field operation activities, field operation activities, and at-field operations closeout. During field operation activities, appropriate contractor personnel will review and evaluate field changes.

An explosives ordnance disposal (EOD) expert will be employed to oversee all UXO recovery and disposal operations. Unexploded ordnance trained personnel will perform the required field activities, including, but not limited to, the following activities:

- $\quad$ Surface and subsurface clearance of UXO

- Anomaly investigation, identification, removal, and disposal

- Inspection, demilitarization, certification, and disposal activities.

Personnel specifically trained in geophysical investigation services will be utilized for locating UXO and suspect anomalies. Specific duties will include performing magnetometer surveys, data processing and interpretation, anomaly reacquisition, and reporting.

\subsection{Design Criteria}

The primary objective of this remedial action is to mitigate potential human health risk from inadvertent contact with UXO. The secondary objective of this remedial action is to inhibit the potential exposure for human and environmental receptors and to minimize the spread of contamination and potential impact on the Snake River Plain Aquifer. This secondary objective only applies to soils that have been contaminated by explosives from the disposal of UXO by high-order detonation or soils at the MDA with contaminant concentrations exceeding the remediation goals as defined in the ROD (DOE-ID 2002). 


\subsubsection{Management Control Procedures}

The project definition, project planning, project execution, and project acceptance and closeout phases will be performed in accordance with the pertinent contractor's internal company procedures. Pertinent internal company procedures for this project are those identifying requirements in the following areas:

- $\quad$ Engineering design

- $\quad$ Emergency preparedness and management

- $\quad$ Fire protection

- Management systems

- Occupational safety and health

- Security

- Environmental restoration

- Waste management

- Conduct of operations and maintenance

- Quality

- Cultural resources.

\subsubsection{Selected Remedy}

Activities at the ordnance areas that may have left UXO behind include aerial bombing practice, naval artillery testing, detonation research, explosives storage bunker testing, and ordnance disposal. Any UXO remaining in these areas can pose a physical risk to human safety, since an explosion can be triggered from handling or contact, especially by machinery. Alternative 3, UXO detection, removal, and institutional controls, was the selected remedy for the ordnance sites to mitigate potential human health risk from inadvertent contact with UXO. The remediation of the five specified ordnance areas will include the following activities:

- Maintain institutional controls consistent with land use that were implemented as part of the OU 10-04 Phase I activities. The specific goals of the institutional controls are to control human activity at sites with suspected UXO contamination and prevent harm from unintentional detonation of UXO. Institutional controls include access restrictions, excavation restrictions, restrictive covenants, and other restrictions such as signage and educational programs. Institutional controls will be maintained until the UXO hazard is removed or reduced to levels acceptable for current and anticipated future land use. Institutional controls will be reassessed as needed to reflect findings during the UXO survey and removal actions that might impact the protectiveness of the Phase I selected controls.

- $\quad$ Perform visual and geophysical surveys for the presence of UXO.

- Investigate potential UXO targets identified during the survey.

- Identify and define the boundaries of the firing and bombing impact areas and the weapons testing and ammunition detonation areas. 
- Determine the ordnance density, explosive characteristics of the UXO, and ordnance accessibility.

- Determine the relative risks of land use based on the type, amount, and accessibility of UXO and determine the extent of UXO removal required to meet desired land use objectives.

- $\quad$ Perform surface clearance, surface geophysical investigations, and intrusive UXO removal with disposal by detonation at the MDA or in-place detonation. Address waste generated during detonation activities using current disposal practices.

- Dispose of other recovered non-ordnance items, such as shrapnel, at an approved landfill on the INL or send the items off the INL for recycling. If secondary explosive contamination, such as TNT or RDX, is discovered, perform remediation as described for the TNT/RDX-contaminated soil sites.

- $\quad$ Backfill excavated areas deeper than $1 \mathrm{ft}$, contour to match the surrounding terrain, and vegetate.

Geophysical surveys will be conducted over the five sites described in Section 1.2 to identify potential UXO. Anomalies detected from the surveys will be noted and further investigated to determine whether intrusive investigation is necessary to remove the suspect items. Any items removed that are determined to be UXO will be transported to the MDA for disposal by high-order detonation. If the UXO poses an unacceptable risk for safe retrieval and transport, it will be disposed of in place by high-order detonation. Detonation of UXO will be performed in a manner that does not pose an unacceptable risk to human health or the environment and meets the minimum distance to the property of others as specified in the RCRA regulation, "Open burning: Waste Explosives."

Sampling will be performed to determine if products of incomplete combustion are present following the completion of all explosive and UXO disposal operations at the MDA (or other areas where UXO is detonated in place). Although detectable levels are not expected, remediation of soil contamination at those sites where residual risk exceeds $1 \mathrm{E}-04$ will be performed. Other non-UXO items recovered as the opportunity presents itself, such as shrapnel, will be disposed of at an appropriate landfill at the INL or sent off-Site for recycling, as appropriate.

Geophysical investigations for buried munitions are seldom $100 \%$ effective. In many cases, a munition is buried too deep, is too small to be detected, or is constructed of a material difficult to detect. Later, through frost heave, erosion, or construction, the item can reach the surface. Also, because the total amount of munitions buried at a site is almost never known, complete recovery cannot be documented. Therefore, periodic surveys may be required in accordance with the Operations and Maintenance Plan for Operable Units 6-05 and 10-04, Phase I (DOE-ID 2004).

Institutional controls have been implemented in accordance with the INL Sitewide Institutional Controls Plan (DOE-ID 2006c). Institutional controls will be maintained at the ordnance areas until the UXO hazard is removed or reduced to acceptable levels. Controls are required to restrain human activity in areas with suspected UXO contamination and prevent harm from unintentional detonation of UXO.

Access to the INL Site is currently restricted for purposes of security and public safety. Sitewide access restrictions will limit accessibility until at least 2095, based on the Comprehensive Facility and Land Use Plan (INEEL 2003a). Installation of additional fences or relocation of the existing fences may also be necessary. Other access control measures currently include warning signs and established training requirements for persons allowed access. Land-use restrictions will be specified if government control of the INL is not maintained throughout the institutional control period. 
For the other two areas, the Arco High-Altitude Bombing Range and the Twin Buttes Bombing Range, ordnance has largely consisted of sand-filled practice bombs that do not pose an explosion risk. Ordnance encountered in these areas will be addressed under the Phase I Operations and Maintenance Plan that allows for the recovery and disposal of ordnance that poses an imminent risk to human health or the environment.

\subsection{Engineering Standards} standards.

Relevant Idaho Cleanup Project (ICP) specifications contain references to the latest engineering

\subsection{Environmental and Safety}

The following is a list of potential chemical-specific and action-specific ARARs identified in the OU 10-04 ROD (DOE-ID 2002). A detailed discussion of the ARARs is presented in Section 4.2, "Applicable or Relevant and Appropriate Requirements."

\section{Chemical-specific ARAR:}

- Idaho Administrative Procedures Act (IDAPA) 58.01.11.200, "Ground Water Quality Standards."

\section{Action-specific ARARs:}

- IDAPA 58.01.01.650, "Rules for Control of Fugitive Dust"

- IDAPA 58.01.01.651, "General Rules"

- IDAPA 58.01.05.006. "Standards Applicable to Generators of Hazardous Waste"

- $\quad$ IDAPA 58.01.05.008, "Standards for Owners and Operators of Hazardous Waste Treatment, Storage, and Disposal Facilities"

- $\quad 40$ Code of Federal Regulations (CFR) 262.11, "Hazardous Waste Determination"

- $\quad 40$ CFR 264.1(j)(1-13), "Purpose, Scope, and Applicability"

- $\quad 40$ CFR 264.114, "Disposal or Decontamination of Equipment, Structures, and Soils"

- $\quad 40$ CFR 264.171, "Condition of Containers"

- $\quad 40$ CFR 264.172, "Compatibility of Waste with Containers"

- $\quad 40$ CFR 264.173, "Management of Containers"

- $\quad 40$ CFR 264.174, "Inspections"

- $\quad 40$ CFR 264.175, "Containment"

- $\quad 40$ CFR 264.176, "Special Requirements for Ignitable or Reactive Waste"

- $\quad 40$ CFR 264.177, "Special Requirements for Incompatible Wastes"

- $\quad 40$ CFR 265.382, "Open Burning; Waste Explosives”

- $\quad 40$ CFR 266.205, "Standards Applicable to the Storage of Solid Waste Military Munitions"

- $\quad 40$ CFR 266.206, "Standards Applicable to the Treatment and Disposal of Waste Military Munitions." 


\section{Location-specific ARARs:}

- $\quad 16$ USC $\S 470 h-2$, "Historic Properties Owned or Controlled by Federal Agencies"

- 25 USC $\S 3002$, “Ownership"

- 25 USC $\S 3005$, "Repatriation"

- 36 CFR 800.4, "Identification of Historic Properties"

- 36 CFR 800.5, “Assessment of Adverse Effects”

- $\quad 43$ CFR 10.6, "Custody"

- $\quad 43$ CFR 10.10, "Repatriation.”

\section{To-be-considered:}

- $\quad$ U.S. Department of Defense (DOD) Standard 6055.9, Chapter 12, "Real Property Contaminated with Ammunition, Explosives, or Chemical Agents" (DOD 2004). 


\section{REMEDIAL DESIGN}

\subsection{Project Site}

This section describes the remedial design for the UXO-contaminated sites. The remedial design was developed in accordance with the engineering design criteria presented in Section 2, "Design Basis." The following subsections summarize the major aspects critical to the remedial design.

\subsection{Previous Actions}

DOE-ID has completed an interim action, four time-critical removal actions, and one non-time-critical removal action for WAG 10 under the OU 10-05 ROD (DOE-ID 1992), and Phase I of IV remedial actions pursuant to the OU 10-04 comprehensive ROD (DOE-ID 2002). The following sections summarize the activities previously performed.

\subsubsection{Operable Unit 10-05 Interim Action}

In 1992, the Declaration of the Record of Decision for Ordnance Interim Action Operable Unit 10-05 (DOE-ID 1992) under OU 10-05 addressed the remediation of 170 acres at six ordnance sites. The sites shown in Figure 1-2 are (with ordnance area number from figure key in parentheses) as follows: the CFA-633 naval firing site (3), the Central Facilities Area (CFA) gravel pit and french drain (4), the explosive storage bunkers (7), the National Oceanic and Atmospheric Administration (NOAA) site (8), the Fire Station II zone and range fire burn area (10), and the Anaconda power line (11). The specific mission of the interim action was to locate, identify, detonate, and dispose of UXO and associated shrapnel and to characterize, remove, and incinerate soils contaminated with explosive residues at the six sites.

During the activities prescribed by the ROD, the action destroyed 130 pieces of UXO, detonated $134 \mathrm{lb}$ of TNT and $104 \mathrm{lb}$ of RDX, incinerated (off-Site) $185 \mathrm{yd}^{3}$ of contaminated soil, and landfilled $8,423 \mathrm{lb}$ of metal fragments.

As outlined in the Declaration of the Record of Decision for Ordnance Interim Action Operable Unit 10-05 (DOE-ID 1992), the selected remedy for the interim remedial action included the following activities:

- A comprehensive search of historical records pertaining to the NPG and other suspected ordnance sites at the INL Site

- $\quad$ Posting of signs where the public has access to ordnance areas

- A visual and geophysical field search of the six identified areas for UXO

- Removal of ordnance and explosive particulate

- Controlled detonation of the ordnance

- Field sampling of detonation areas and other areas suspected of contamination with explosive compounds

- $\quad$ Excavation of contaminated soils exceeding action levels

- Verification sampling of excavated areas

- Off-Site incineration and disposal of contaminated soils. 
This alternative was preferred over the others outlined in the ROD, because it best achieved the goals of the evaluation criteria, given the scope of the action.

A baseline risk assessment was not completed for OU 10-05 at the time of the interim action ROD but has subsequently been performed under the OU 10-04 comprehensive ROD. The main risk associated with the six sites addressed under the interim action was the potential explosive hazard associated with the uncontrolled detonation of UXO. To that end, the primary purpose of the interim action was to reduce those risks by finding and disposing of UXO from the six areas identified for the interim action.

Additional risks resulting from exposure to soils contaminated with explosive residues also were addressed during the interim action. Risk-based soil concentrations were back-calculated from the established National Contingency Plan target risk range of 1E-04 to 1E-06 for carcinogenic contaminants and a hazard index of 1 for noncarcinogenic contaminants. Based on those criteria, screening action levels of $440 \mathrm{mg} / \mathrm{kg}$ for TNT and $180 \mathrm{mg} / \mathrm{kg}$ for RDX were selected to address soils that had concentrations of contaminants exceeding the 1E-04 risk-based soil levels, with cleanup standards for the interim action of $44 \mathrm{mg} / \mathrm{kg}$ for TNT and $18 \mathrm{mg} / \mathrm{kg}$ for RDX based on the $1 \mathrm{E}-05$ risk-based soil concentrations.

The results of the OU 10-05 interim action are documented in the Remedial Action Report for the Interim Action to Cleanup Unexploded Ordnance Locations at the INEL (Operable Unit 10-05) (Wyle 1994). Ordnance was located and either disposed of by detonation or demilitarized, while the scrap metal was disposed of at the CFA landfill, and the explosive was disposed of by detonation. Items included an electric squib, illumination candles, grenades, projectiles, fuze components, and miscellaneous UXO. During searches to locate UXO, evidence of soil contamination was found and flagged for sampling. Soil contamination was noted at Fire Station II, the CFA-633 naval firing site, and the NOAA area. Locations identified during the sampling effort that exceeded the action levels of $440 \mathrm{mg} / \mathrm{kg}$ TNT and $180 \mathrm{mg} / \mathrm{kg}$ RDX were excavated and containerized for shipment off-Site for disposal by incineration. In most cases, the sampling results indicated that the contamination was limited to within 4 in. of the surface. An iterative process of excavation followed by verification sampling was implemented to ensure that contamination exceeding the action levels had been removed. A total of 201 $1-\mathrm{yd}^{3}$ boxes were filled with contaminated soil, most of which originated from the CFA-633 area, with smaller amounts coming from the NOAA and Fire Station II areas. The areas impacted by the excavation activities were reseeded.

\subsubsection{Non-Time-Critical Removal Action}

A 1994 non-time-critical removal action addressed 141 acres consisting of three ordnance sites, including NODA (surface only), four 16-in. shells located east of Lincoln Boulevard near Mile Marker 17, and the Twin Buttes Bombing Range. The primary objective of the removal action was to mitigate the hazard of uncontrolled detonation of ordnance to site workers, facilities, and public roads. A secondary objective of the removal action was to provide information for planning and conducting the overall OU 10-03 ordnance areas assessment scheduled for 1998. The 1994 action destroyed 1,408 pieces of UXO, detonated $22 \mathrm{lb}$ of bulk high explosives, and landfilled 70,440 lb of metal fragments. The vast majority of the pieces of UXO and all the bulk high explosives disposed of in 1994 were recovered from the NODA. Of the 1,447 items recovered from the Twin Buttes Bombing Range, only six were live ordnance (e.g., fuze assemblies) requiring disposal by detonation, with the majority of these being practice bombs. The 1994 non-time-critical removal action continued into 1995, when it addressed 22.56 acres of subsurface ordnance at NODA. This 1995 action also destroyed 462 pieces of UXO, detonated $18 \mathrm{lb}$ of bulk high explosives, and landfilled 39,470 lb of metal fragments. The remediated ordnance inventory (DOE-ID 1998, Appendix K) summarized findings by size and disposal method. 
The Removal Action Report for the Ordnance Removal Action, Operable Unit 10-03 (Wyle 1995a) summarizes the work performed in 1994, and the Addendum to the Removal Action Report for the Ordnance Removal Action, Operable Unit 10-03 (Wyle 1995b) updates the report as to the work completed in 1995. Work-specific tasks included mobilization to the site, a visual UXO search of the site followed by a geophysical search, and ordnance and scrap removal. The located UXO was either destroyed in place or transported to the MDA for disposal by high-order detonation. Demilitarized UXO was inspected to ensure that no hazard remained and was then taken to the CFA landfill for disposal.

Additionally, it was planned that the action would address three TNT- and RDX-contaminated soil sites including the CFA-633 naval firing site, the NOAA area, and the Fire Station II area. The primary objective for the contaminated soil sites was to mitigate the potential excess cancer risk associated with personnel inhalation, ingestion, and dermal absorption of soils contaminated with TNT and RDX. The secondary objective was to identify a cost-effective method for treating soil contaminated with explosive residues at the INL site.

The cleanup standards for the TNT- and RDX-contaminated soil sites were $44 \mathrm{ppm}$ for TNT and $18 \mathrm{ppm}$ for RDX. The cleanup standards represented the maximum concentration of soil contaminants allowed to remain in place after excavation of the contaminated locations. The standards were based on the results of risk analysis conducted for the OU 10-03 interim remedial action, with concentrations of $44 \mathrm{ppm}$ for TNT and $18 \mathrm{ppm}$ for RDX representing an excess cancer risk of $1 \mathrm{E}-05$ based on an occupational dermal contact exposure scenario. This scenario was selected because it resulted in the lowest risk-based concentrations for the exposure pathway.

The selected remedy for the TNT- and RDX-contaminated soils was bioremediation. A treatability study was completed in 1999, as documented in the Waste Area Group 10 RDX/TNT CERCLA Treatability Study Final Report (INEEL 2000). The study demonstrated that the technology was technically feasible; however, the OU 10-04 comprehensive ROD (DOE-ID 2002) provides a selected remedy of removal by excavation over bioremediation. The TNT and RDX portion of the 1994 non-time-critical removal action was not completed but will be addressed under Phase II of the OU 10-04 remedial action scheduled for 2007.

\subsubsection{Time-Critical Removal Action}

As outlined in the U.S. Department of Energy, Idaho Operations Office Lead Agency Action Memorandum Time-Critical Removal Action Ordnance Areas Operable Unit 10-03 Idaho National Engineering Laboratory (INEL) (INEL 1996), a time-critical removal action was selected as the alternative to address 45 acres consisting of four ordnance sites, including UXO east of the RTC, the Rail Car Explosion Area, the Land Mine Fuze Burn Area, and the projectiles in the riverbed adjacent to the rail car area. The action was carried out based on a report issued in May 1996 by the Army Corps of Engineers with a time-critical removal action being justified if the ordnance was exposed and directly threatened human lives. The four areas met these criteria.

To accomplish the goal of mitigating the threat from the ordnance, the purpose of the time-critical removal action was to locate, clear, and detonate UXO and clear ordnance and explosive waste at the four sites. The action destroyed 221 pieces of UXO, detonated $64 \mathrm{lb}$ of bulk high explosives, and landfilled 40,250 lb of metal fragments. The results of the 1996 time-critical removal action are documented in the Final Action Report for the Time Critical Removal Action, Operable Unit 10-03 (Parsons 1997). The primary tasks included mobilization to the site, visual search for UXO, ordnance and scrap removal, a geophysical search for UXO followed by analysis of geophysical survey data, demilitarization of ordnance items, and disposal of ordnance and explosive items by detonation. Within the Land Mine Fuze Burn Area, a total of 1,018 individual fuzes were removed, 118 of which contained 
explosives. Additionally, over 36,000 lb of scrap and approximately $60 \mathrm{lb}$ of raw explosives were removed from the area. Scrap removed from the Rail Car Explosion Area included over 4,250 lb of inert materials, including rail car components and ordnance residue. In addition, several other explosive items, including portions of 18 aerial bombs and ten 5-in. projectiles, were collected from various locations and destroyed during demolition operations. All loose explosives encountered during the project were collected and destroyed during the demolition of the UXO.

\subsubsection{Non-Time-Critical Removal Action}

As outlined in the Engineering Evaluation Cost Analysis for Nontime-Critical Removal Action for Unexploded Ordnance at the Idaho National Engineering and Environmental Laboratory Operable Unit 10-03 (DOE-ID 1997), a 1997 non-time-critical removal action addressed 284 acres at eight ordnance sites: NODA (111 acres), the Rail Car Explosion Area (52 acres), the MDA (74 acres), the NOAA site (27.3 acres), the Experimental Field Station ( 2 acres), Fire Station II (2.5 acres), the craters east of INTEC (10 acres), and the Land Mine Fuze Burn Area (5 acres).

The recommended alternative for the removal action was search and detonation of UXO. This alternative was selected, because it was the only choice that fully mitigated the explosive hazard to INL Site workers. It was a proven method of eliminating the explosive hazard of uncontrolled detonation and was a cost-effective remedy that could be implemented in a timely fashion. The primary objective of the removal action was to mitigate the explosive hazard of uncontrolled detonation of ordnance to INL Site workers. The secondary objective was to remove the soil contaminated with explosives. Sites identified as exceeding the remediation goals were evaluated and remediated in 1998. The remediation goals for TNT, RDX, and dinitrotoluene were $47 \mathrm{mg} / \mathrm{kg}, 180 \mathrm{mg} / \mathrm{kg}$, and $35 \mathrm{mg} / \mathrm{kg}$, respectively. The action destroyed 146 pieces of UXO, detonated $343 \mathrm{lb}$ of bulk high explosives, and landfilled 40,182 lb of scrap.

The Summary Report for the 1997 Non-Time Critical Removal Action for Ordnance at Operable Unit 10-03 (INEEL 1999) presents the results of the 1997 non-time-critical removal action. Ordnance removal was completed at four of the eight sites: the NOAA grid, the Fire Station II zone, the Experimental Field Station, and the craters east of INTEC. Further removal of ordnance was required at the remaining four sites after the 1997 non-time-critical removal action was completed. The removal action at these four sites was not completed in 1997 because of programmatic funding constraints.

However, the removal action for the NODA grid was completed as part of the 2004 time-critical removal action. Removal actions for the MDA, the Rail Car Explosion Area, and the Land Mine Fuze Burn Area will be addressed as part of the Phase IV activities defined herein.

\subsubsection{Time-Critical Removal Action}

As outlined in the U.S. Department of Energy Idaho Operations Office, Lead Agency Action Memorandum Time-Critical Removal Action for Unexploded Ordnance, Operable Unit 10-04, Idaho National Engineering and Environmental Laboratory (INEEL 2003b), a time-critical removal action was warranted to remove UXO discovered after a range fire burned through an area between CFA and the RTC. In addition, several "live" pieces of UXO were discovered east of INTEC. The action addressed the removal and disposal by detonation of 62 pieces of UXO found at NODA and four pieces east of INTEC, including fifty-five 5-in. anti-aircraft common rounds and 11 fuzes.

The primary objective of the 2004 time-critical removal action was to remove exposed UXO from critical areas at the INL Site. The projectiles and fuzes identified in these areas presented an imminent risk to INL Site personnel and the public. Guidance from the Army Corps of Engineers indicates that a time-critical removal action is warranted in situations where there is an immediate threat due to exposure to ordnance with the risk of serious injury or death. The critical areas identified for the 2004 time-critical 
removal action contained 5-in. anti-aircraft projectiles and fuzes that presented an explosion hazard due to high explosives. In addition to the explosion hazard, the items also presented a security risk of deliberate detonation.

The Summary Report for the 2004 Time-Critical Removal Action for Unexploded Ordnance at Operable Unit 10-04 (ICP 2004) summarizes the results of the 2004 time-critical removal action. The objective of the time-critical removal action was to remove, transport, and destroy UXO that was found near the NODA and INTEC. The UXO was recovered, transported to the MDA, and destroyed by high-order detonation. A total of fifty-five 5-in. anti-aircraft common rounds and 11 fuzes were recovered and disposed of.

\subsection{Site Contaminant Summary}

The following sections summarize the contamination at the NODA, the MDA, the Experimental Field Station, the Rail Car Explosion Area, and the Land Mine Fuze Burn Area. Based upon historical records and previous removal actions, these five sites pose the greatest risk from UXO. Of the five sites, the greatest concentrations of UXO have been located at the NODA and the Land Mine Fuze Burn Area.

The contaminants of concern for these sites include UXO, RDX, TNT, 1,3-dinitrobenzene, and lead. RAOs for the sites were developed in accordance with the "National Oil and Hazardous Substances Pollution Contingency Plan" (NCP) (40 CFR 300) and EPA guidance (EPA 1988) and through the consensus of DOE-ID, EPA, and DEQ participants. The RAOs are based on the results of both the human health risk assessments and ecological risk assessments and are specific to the contaminants of concern and exposure pathways developed for OU 10-04 (DOE-ID 2002).

\subsubsection{Naval Ordnance Disposal Area}

Historically, this area was used by the Navy as a disposal area and experimental site. Activities deposited pieces of explosive compounds, ordnance, and ordnance components over the site. Previous removal actions addressing the NODA have included the 1994 non-time-critical removal action, the 1997 non-time-critical removal action, and the 2004 time-critical removal action.

During the 1994 non-time-critical removal action, a total of 461 suspected pieces of ordnance were marked and logged, with 1,400 $\mathrm{lb}$ destroyed by high-order detonation. In addition, $2 \mathrm{lb}$ of TNT and $10 \mathrm{lb}$ of RDX were removed and destroyed. The ordnance consisted primarily of fuzes and small projectiles, with small quantities of booster cups, tracers, projectile base plates with tracers, and an igniter. An additional 32,850 $\mathrm{lb}$ of ordnance-related debris were recovered and shipped to the CFA landfill for disposal. The non-time-critical removal action continued into 1995, during which time 462 pieces of $\mathrm{UXO}$ and $18 \mathrm{lb}$ of bulk high explosives were disposed through high-order detonation and 39,470 lb of metal fragments were sent to the landfill.

The 1997 non-time-critical removal action resulted in the recovery of 107 pieces of ordnance, $14,798 \mathrm{lb}$ of ordnance-related scrap, and $159 \mathrm{lb}$ of non-ordnance-related scrap. The ordnance recovered was similar to that recovered during the 1994 action. During the 2004 time-critical removal action, a total of 11 fuzes and fifty-one 5-in. antiaircraft common rounds were recovered and disposed of by high-order detonation at the MDA. 
Figure 3-1 depicts the cleared, assessed, and uncleared ordnance areas at the NODA site. A cleared area is one in which the area has been surveyed for ordnance and any ordnance found has been removed and disposed of by high-order detonation. An assessed area is one in which the area has been surveyed for ordnance and there is a potential of live ordnance remaining in the area based upon evidence of ordnance (e.g., fragments) even though none was previously found and removed. An uncleared area has not been surveyed and no action has been taken to remove any ordnance from the area. The figure provides the locations where samples were collected in support of the OU 10-04 RI/FS. The inert UXO and fragments shown on the map consist primarily of fragments and are currently known to be present at the site. The former live UXO locations represent the UXO that was retrieved in support of the 2004 time-critical removal action. During the 2005 long-term ecological monitoring effort, five plots were laid out at the NODA for trapping small mammals. No UXO was encountered within these plot areas shown in Figure 3-1, thereby supporting the assertion that previous removal actions conducted at NODA have been successful in recovering UXO at the site.

\subsubsection{Mass Detonation Area}

Historically, the Mass Detonation Area was used by the Army and Navy to conduct large-scale detonation tests in the 1945 to 1946 timeframe. The tests involved the detonation of explosive-filled magazines containing up to $500,000 \mathrm{lb}$ of explosive ordnance. The purpose of most of the magazine tests was to determine if larger quantities of explosives could be stored in magazines without initiating adjacent magazines. Additionally, there were two sites where 250,000 lb of TNT in land mines were detonated in open revetments. The area has more recently been used as a disposal site for explosives and UXO by high-order detonation.

During the 1993 interim action, five pieces of UXO were recovered and disposed of by detonation. During the 1996 Track 2 field assessment, one antitank mine still in the shipping crate, one live tetryl bomb booster, five empty 40-mm cartridges with live primers, and several inert projectile fuzes were found. Again, these items were disposed of by detonation. The 1997 non-time-critical removal action addressed the remediation of this area, during which five pieces of UXO were recovered and disposed of by detonation, along with $0.25 \mathrm{lb}$ of high explosives, and over 8,600 lb of metal scrap were removed. Unfortunately, the locations of the UXO identified in 1993, 1996, and 1997 were not recorded and, as a result, cannot be shown on a map of the area.

Figure 3-2 depicts the MDA, delineating the cleared, assessed, and uncleared ordnance areas at the site. A cleared area is one in which the area has been surveyed for ordnance and any ordnance found has been removed and disposed of by high-order detonation. An assessed area is one in which the area has been surveyed for ordnance and there is a potential of live ordnance remaining in the area based upon evidence of ordnance (e.g., fragments) even though none was previously found and removed. An uncleared area has not been surveyed and no action has been taken to remove any ordnance from the area. While a high potential for fragments at the MDA exists, locations have not been surveyed; hence, they are not shown in the figure. The figure provides the locations where samples were collected in support of the OU 10-04 RI/FS. During the 2004 long-term ecological monitoring effort, 10 plots were laid out at the MDA for trapping small mammals, with land mine base fuzes encountered in one of the plots. 


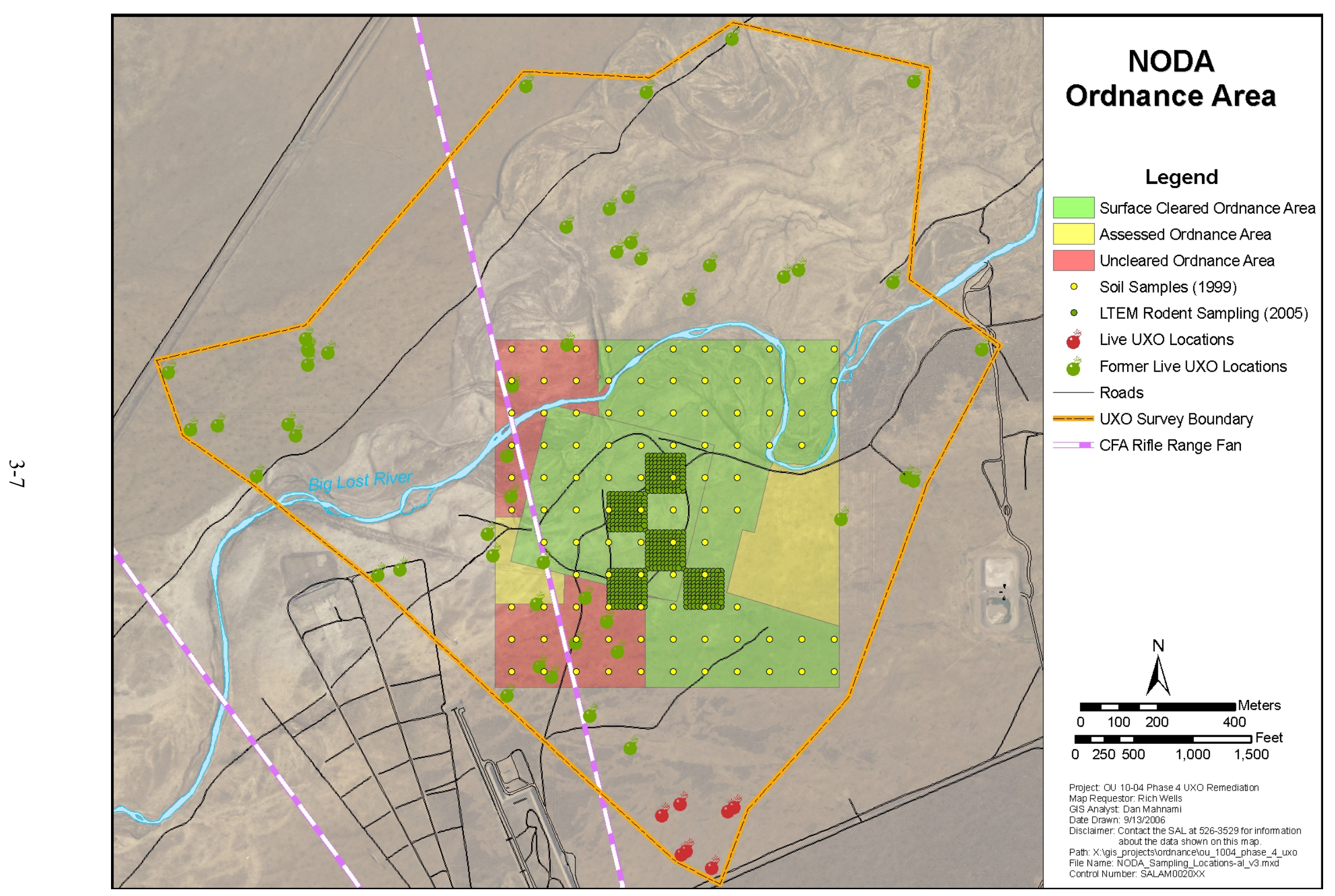

Figure 3-1. Naval Ordnance Disposal Area. 


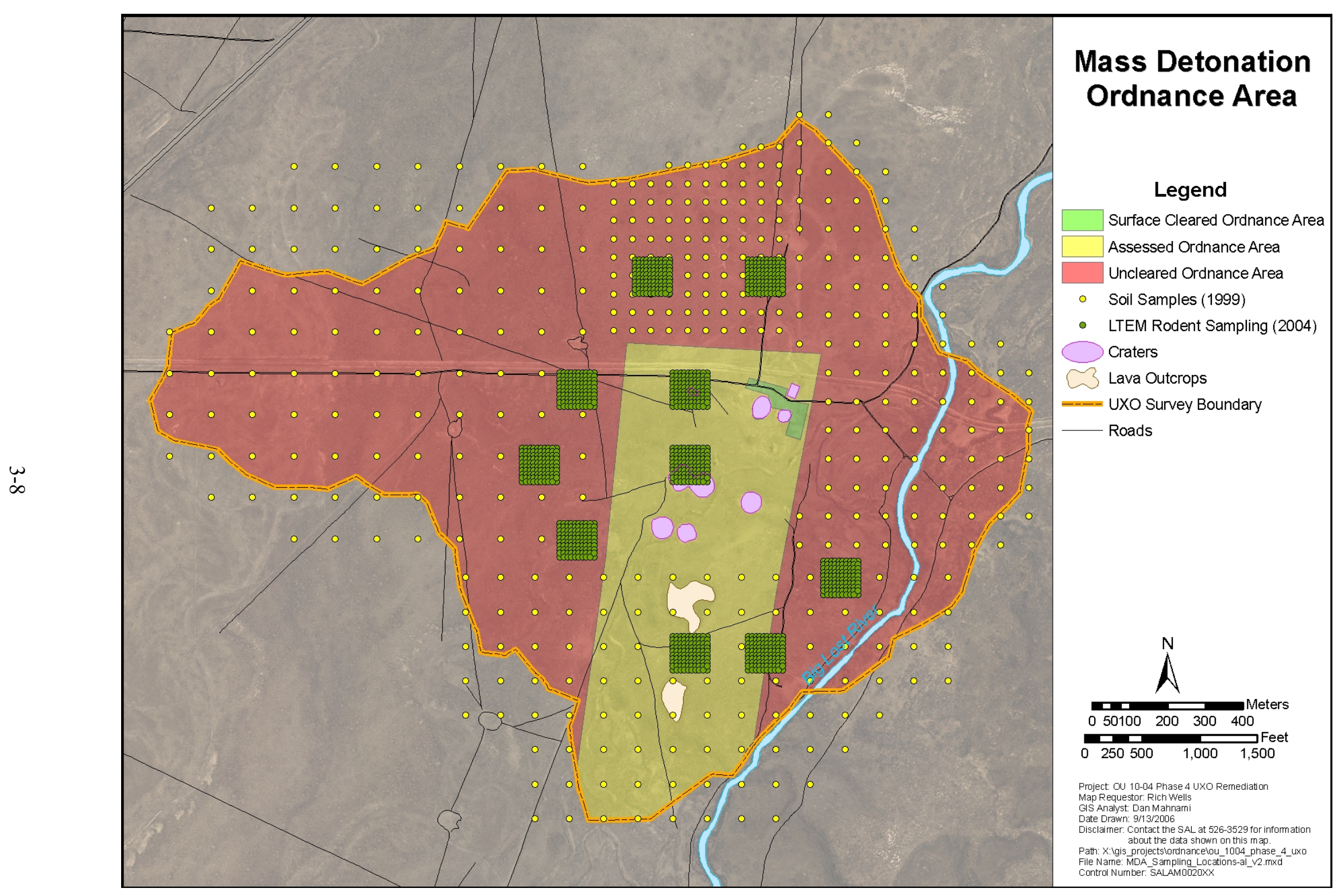

Figure 3-2. Mass Detonation Area. 


\subsubsection{Experimental Field Station}

During the 1996 Track 2 field assessment, a 0.81-ha (2-acre) area was identified as requiring surface clearance because of scattered pieces of explosives and stained soil (DOE-ID 1998). A second area of approximately 0.8 acre was mapped that contained heavy concentrations of TNT-contaminated soil. This was the area recommended for the treatability study previously discussed. The assessment included a visual search for signs of craters, detonation tests, surface UXO, pieces of explosives, and soil contamination. When TNT was encountered, the area was examined in greater detail and mapped. No ordnance was found in any of the craters, which appeared to have resulted from ordnance destruction or ordnance testing. Approximately $1.5 \mathrm{mi}$ away, the nose section of a World War I vintage bomb (as identified by an EOD expert based upon review of military ordnance manuals) with TNT and an empty tail section was found and disposed of by detonation at the MDA during the 1996 removal action. It is unclear why World War I vintage ordnance would be present at the site. Conjecture would lead one to believe that the Navy would use older ordnance for tests performed at the NPG rather than use ordnance with a useful life given the timeframe during which naval operations occurred at the site. No other UXO was found at this site during the 1996 removal action or Track 2 field assessment.

The area was addressed during the 1997 non-time-critical removal action during which $55 \mathrm{lb}$ of bulk high explosives were recovered and disposed of by high-order detonation. In addition, $660 \mathrm{lb}$ of ordnance-related scrap and $100 \mathrm{lb}$ of non-ordnance-related scrap were recovered and disposed of.

Figure 3-3 depicts the Experimental Field Station, delineating the cleared and uncleared ordnance areas at the site. The figure provides the locations where samples were collected in support of the OU 10-04 RI/FS. The inert UXO and fragments shown on the map consist primarily of fragments and are currently known to be present at the site. During the 2003 long-term ecological monitoring effort, one plot was laid out at the Experimental Field Station for trapping small mammals. No UXO was encountered within this plot area shown in Figure 3-3, thereby supporting the assertion that a minimum number of UXO-related items are located at the site.

\subsubsection{Rail Car Explosion Area}

Ordnance and explosives contamination at the Rail Car Explosion Area originated from a test conducted in which five rail cars, each with 30,000 lb of explosives, were detonated on August 31, 1945, to determine the missile distance and hazard that could be expected if a loaded ammunition train detonated. The rail cars were placed in line on a short stretch of track and all 150,000 lb of explosives were detonated simultaneously when the center car was initiated. During the 1996 time-critical removal action, a visual sweep and geophysical survey were performed at the site. In all, a total of 429 anomalies identified during the geophysical survey were investigated using hand-digging techniques, with over 4,250 $\mathrm{lb}$ of inert materials, including rail car components and ordnance residue, being removed from the site. Three live 5-in. projectiles were found during the 1996 removal action and transported to the MDA, along with $25 \mathrm{lb}$ of bulk explosive, for disposal by detonation.

During the 1997 non-time-critical removal action, no UXO was recovered. A total of $0.56 \mathrm{lb}$ of high explosives were recovered and disposed by detonation. In addition, 2,159 lb of ordnance-related scrap and 10,135 lb of non-ordnance-related scrap were recovered and disposed. 


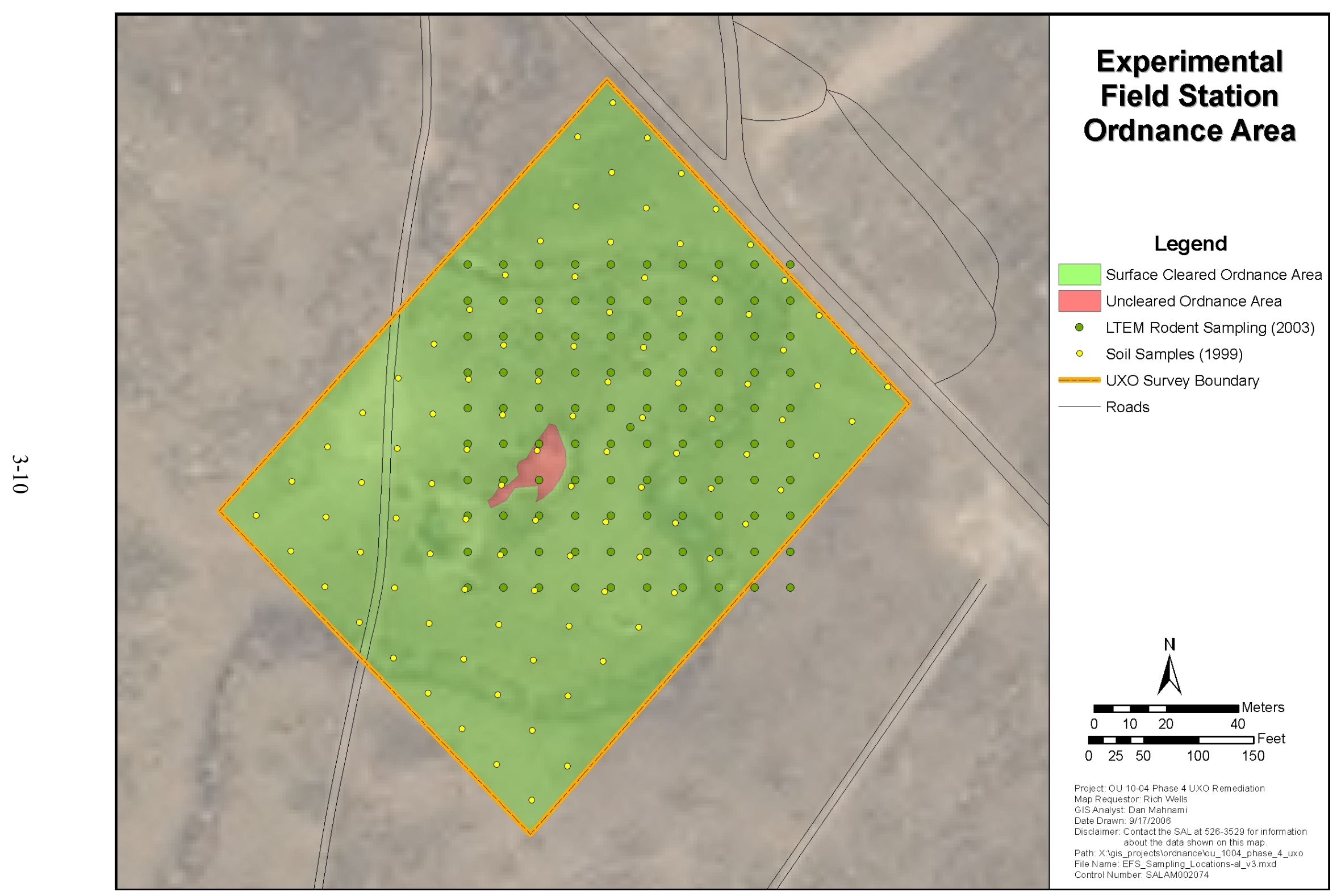

Figure 3-3. Experimental Field Station. 
Figure 3-4 depicts the Rail Car Explosion Area, delineating the cleared, assessed, and uncleared ordnance areas at the site. A cleared area is one in which the area has been surveyed for ordnance and any ordnance found has been removed and disposed of by high-order detonation. An assessed area is one in which the area has been surveyed for ordnance and there is a potential of live ordnance remaining in the area based upon evidence of ordnance (e.g., fragments) even though none was previously found and removed. An uncleared area has not been surveyed and no action has been taken to remove any ordnance from the area. The figure provides the locations where samples were collected in support of the OU 10-04 RI/FS. The inert UXO and fragments shown on the map consist primarily of fragments that are currently known to be present at the site. The live UXO location represents several cracked open shells with base fuzes that are still located in and around a crater within the Rail Car Explosion Area. During the 2005 long-term ecological monitoring effort, five plots were laid out at the Rail Car Explosion Area for trapping small mammals. The presence of the shells was confirmed during the 2005 ecological monitoring activities. The shells were visually identified as 5 -in. projectiles, similar to those that have been located and removed during previous removal actions.

\subsubsection{Land Mine Fuze Burn Area}

Historically, the Land Mine Fuze Burn Area appears to have been a demilitarization and disposal area for land mine fuzes. Most of the land mine fuzes that have been found show evidence of having been burned. However, some did not show any evidence of exposure to fire and appeared to be undamaged. During the 1996 time-critical removal action, a visual surface sweep was performed of the area, along with a geophysical survey, to locate and remove surface and near-surface metallic objects. A total of 1,018 individual fuzes were removed, of which 118 contained explosives. Additionally, a total of over $36,000 \mathrm{lb}$ of scrap and approximately $60 \mathrm{lb}$ of raw explosive also were removed from the area. Inert scrap found and removed consisted primarily of pressure plates, bomb packaging materials, and inert mine fuze bodies.

During the 1997 non-time-critical removal action, 28 UXO-related items consisting of M1A2 mines were recovered and disposed of by detonation. In addition, 2,830 lb of ordnance-related scrap was recovered and disposed of.

Figure 3-5 depicts the Land Mine Fuze Burn Area delineating the cleared, assessed, and uncleared ordnance areas at the site. The figure also provides the locations where samples were collected in support of the OU 10-04 RI/FS. The inert UXO and fragments shown on the map consist primarily of fragments that are currently known to be present at the site. The former live UXO locations represent a number of fuzes still located in the area.

\subsection{Design Assumptions}

The assumptions under which the RD/RA activities will be performed for the remediation of the UXO-contaminated sites are as follows:

- $\quad$ Archeological concerns will be identified before implementation of the remedial action and will not delay planned activities. In the event that the remedial action may impact an area of archeological concern, the INL archeologist will be contacted and appropriate action taken at that individual's direction to mitigate the concern.

- $\quad$ All UXO will be recoverable and transported to the MDA for disposal by high-order detonation. In the case that UXO poses an unacceptable risk for recovery, it will be disposed of in place. 


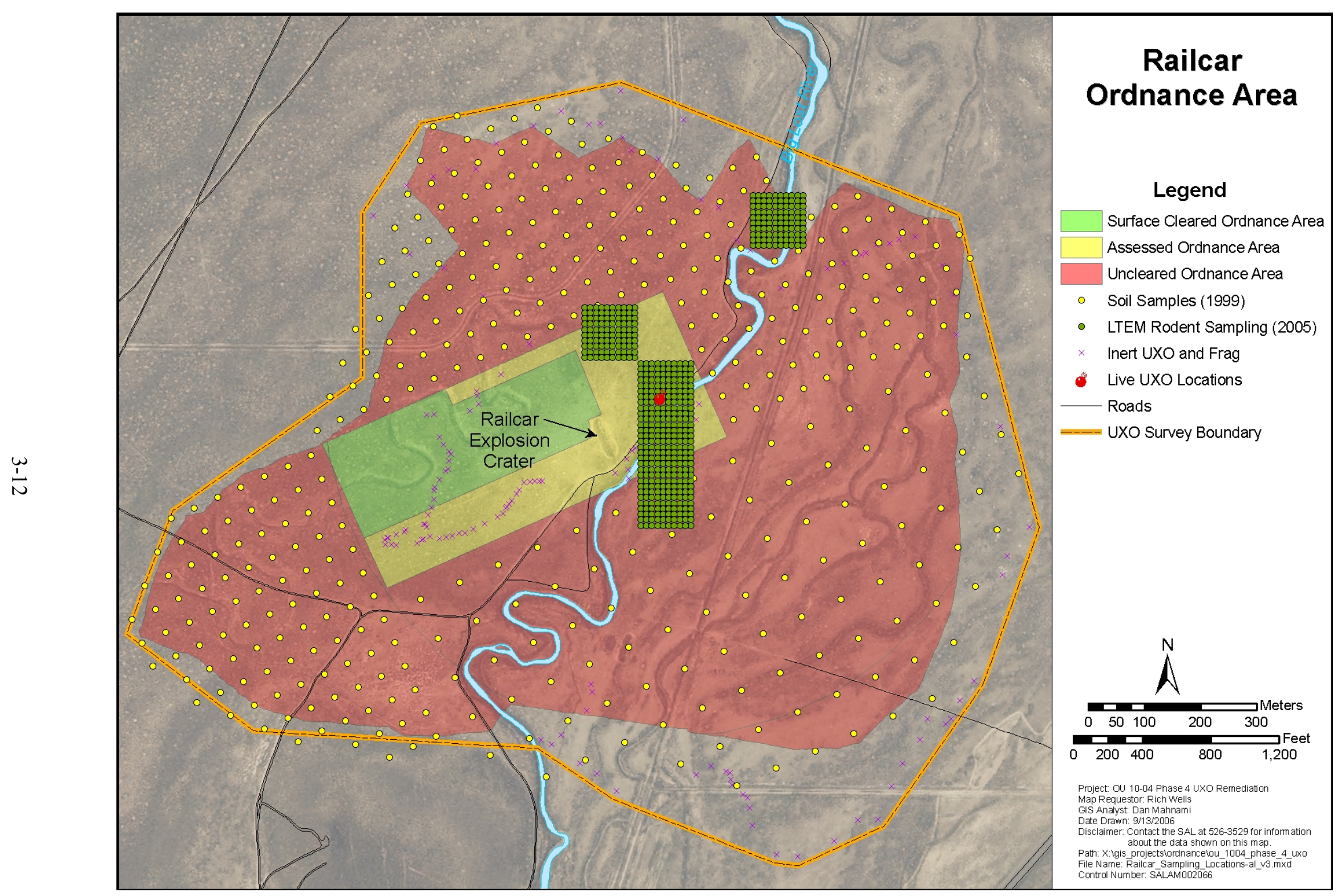

Figure 3-4. Rail Car Explosion Area. 


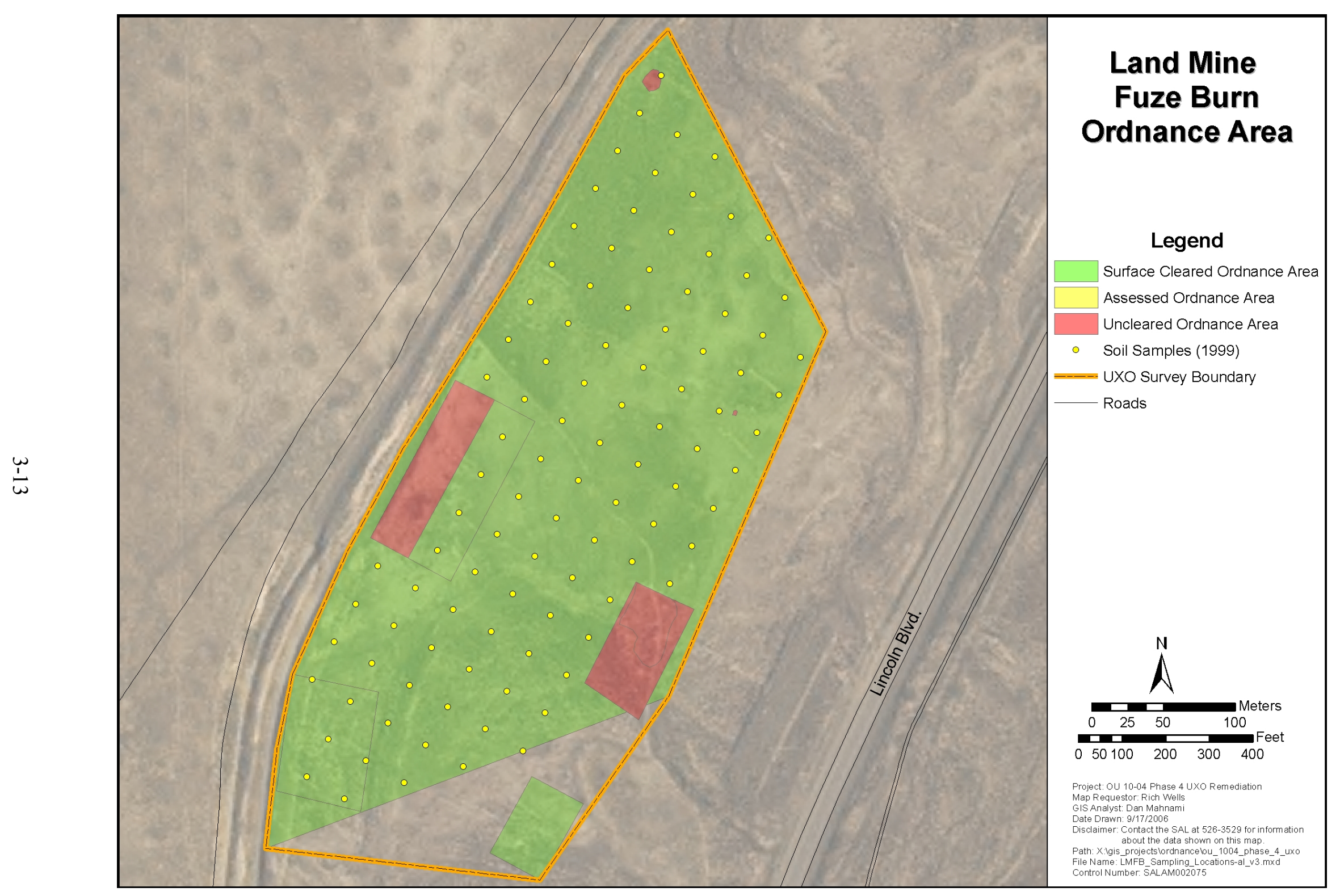

Figure 3-5. Land Mine Fuze Burn Area. 
- With the exception of the MDA, no explosive-contaminated soil will require remediation attributed to the disposal of UXO by high-order detonation. In the case that UXO poses an unacceptable risk for recovery leading to disposal in place, soil that is potentially impacted by the disposal activity will be sampled and remediated as required.

- $\quad$ Compatible waste storage capacity will be available during the remediation activities to ensure that potentially reactive materials are segregated. If current waste storage capacity is exceeded, temporary storage will be provided.

- $\quad$ Explosive-contaminated soil will be disposed of at the Idaho CERCLA Disposal Facility (ICDF) with the exception of soil that exceeds $10,000 \mathrm{mg} / \mathrm{kg}$ for the summed concentrations of the analytes detected by SW-846 Method 8330 (EPA 2002). Soil exceeding the 10,000-mg/kg criterion will require transport to a RCRA treatment, storage, and disposal facility for thermal treatment and disposal.

- $\quad$ The explosive-contaminated soil will meet the ICDF Waste Acceptance Criteria, or a variance will be granted should the criteria be too restrictive as currently written. In the case that a variance is not granted, explosive-contaminated soil will be disposed of at an approved off-Site facility.

- The explosive-contaminated soil will not be determined to be RCRA hazardous based upon laboratory analyses performed during remediation. If the soil is determined to be RCRA hazardous, it will require shipment to an approved off-Site facility for treatment and disposal.

- For explosive-contaminated soil, ecological risks will be reduced by the implementation of the remedial action to reduce the human health risks for the sites presenting both human health and ecological risks. If a contaminant is encountered that the reduction of human health risk does not mitigate the ecological risk, agreement will be made with the Agencies as to how to address the residual risk.

- $\quad$ For explosive-contaminated soil, remediation goals based on hazard quotients of 10 or soil concentrations of 10 times background values are protective of ecological receptors.

- $\quad$ Commercially available geophysical survey methods will be adequate to identify any UXO lying below the surface. If any UXO is encountered for which commercially available geophysical survey methods are not available, additional investigation and technical development will be required.

\subsection{Summary of Phase IV Activities}

The relevant ICP construction specifications outline the details of the work to be conducted in support of the OU 10-04 Phase IV remedial action.

\subsubsection{Naval Ordnance Disposal Area}

Figure 3-1 shows the NODA and locations of known UXO fragments and historical locations of UXO recovered previously. To identify and flag UXO, the site will be surveyed, both visually and using geophysical techniques, in accordance with ICP specifications. Locations of potential UXO will be mapped and further investigated to verify identification of the item. Once all UXO has been positively identified, the field team will retrieve the UXO in accordance with INL procedures and transport the items to the MDA for disposal by high-order detonation. 
It is assumed that all UXO will be recoverable and transported to the MDA for disposal. In the event that a UXO item presents an unacceptable risk for recovery, the item will be disposed of by detonation in place. Soil that is potentially affected by in-place detonation/disposal of UXO will be sampled to assess the residual contamination resulting from the disposal activity. Should the soil prove to present an unacceptable risk to human health or the environment, the soil will be excavated by hand or with a small excavator to an initial depth of approximately $7.5 \mathrm{~cm}(3 \mathrm{in}$.). The excavated soil will be placed in containers or stockpiled at a single location on the site. Appropriate dust-suppression techniques will be used to minimize the generation of fugitive dust and to mitigate exposure of personnel to any airborne contamination.

Using field-screening methodology as specified in the Field Sampling Plan for the Operable Units 6-05 and 10-04 Remedial Action, Phase IV (DOE-ID 2006a), the soil at the bottom of the excavation will be analyzed for TNT and RDX. If the results are below the remediation goals defined in the OU 10-04 ROD (DOE-ID 2002), then no further excavation will be required. If the results exceed the remediation goal, another $7.5-\mathrm{cm}$ (3-in.) lift will be performed, followed by reanalysis of the remaining soil. This iterative process will continue until the contaminant concentrations in the remaining soil are below their respective remediation goals.

Geophysical screening with an all-metal detector will be used to confirm that no additional items are present below the bottom of the last lift. These results will be recorded in the field logbook along with the result of the analytical screening and any observations of soil conditions indicating that native soil has been reached or indicating that any observed staining or other visual evidence of contamination has been removed.

If excavation is required, sampling of the affected soil will be performed in accordance with the Field Sampling Plan for the Operable Units 6-05 and 10-04 Remedial Action, Phase IV

(DOE-ID 2006a). Based on the results of the confirmatory sampling, additional excavation may be required. Once it is confirmed that the remediation goals have been achieved, the excavated area will be contoured to match the surrounding terrain and revegetated, as necessary.

The excavated soil will be characterized, as necessary, to ensure compliance with the Waste Acceptance Criteria for the selected disposal facility (e.g., the ICDF). In accordance with Section 9.9 of the ROD (DOE-ID 2002), if the summed concentrations of TNT and RDX exceed 10\%, the soil will be transported to a permitted RCRA treatment, storage, and disposal facility for thermal treatment and disposal. To be conservative, if the sum of all analytes detected by SW-846 Method 8330 (EPA 2002) in the excavated soil exceeds $10,000 \mathrm{mg} / \mathrm{kg}(10 \%)$, the soil will be sent for thermal treatment and disposal.

\subsubsection{Mass Detonation Area}

Figure 3-2 provides an overview of the MDA, delineating locations of previous sampling activities at the site. The MDA will be the last of the UXO sites addressed under this Phase IV work plan because the other sites must be completed and the UXO and explosives from those sites must be disposed of by high-order detonation before remediation can take place at the MDA. The MDA will be remediated in two primary stages. The first stage will consist of surveying of the site using both visual and geophysical methods to identify any UXO remaining at the site. As with the NODA, the potential UXO will be mapped and investigated to verify identification of the items, followed by retrieval of positively identified UXO and disposal by high-order detonation. As with the other UXO sites, if a UXO item poses an unacceptable risk for recovery, the item will be disposed of by detonation in place.

Following completion of remediation activities at other OU 10-04 sites where UXO or explosives pose a hazard and upon completion of the UXO remediation stage at the MDA, soil sampling of the MDA 
will occur to determine whether any of the disposal activities have adversely impacted the area such that the contaminated soil poses an unacceptable risk to either human health or the environment. Based upon historical sampling at the MDA conducted in support of the OU 10-04 RI/FS and sampling performed in support of ecological monitoring, the soil at the MDA does not pose an unacceptable risk. Therefore, soil sampling will be limited to the pit and soils immediately surrounding the pit where disposal activities take place.

Soil samples collected from the potentially impacted area will be analyzed for nitroaromatics. If the nitroaromatic results are below the remediation goals defined in the OU 10-04 ROD (DOE-ID 2002), no remediation of the soil will be required. If the results exceed the remediation goals, an iterative process of excavation followed by sampling will occur until the contaminant concentrations in the remaining soil are below their respective remediation goals. As with the NODA, sampling will follow the protocol outlined in the Field Sampling Plan for the Operable Units 6-05 and 10-04 Remedial Action, Phase IV (DOE-ID 2006a). Based upon confirmation that the remediation goals have been achieved, the excavated area will be backfilled, if necessary, and contoured to ensure compliance with storm water requirements. As with the NODA, excavated soil will be characterized, as necessary, to ensure compliance with the applicable Waste Acceptance Criteria and regulatory disposal requirements.

\subsubsection{Experimental Field Station}

Figure 3-3 presents the Experimental Field Station and locations of known inert UXO and fragments. The approach for remediation of the Experimental Field Station will be similar to that outlined for the NODA. Based upon historical results of previous interim actions conducted at the Experimental Field Station, it is anticipated that the quantity of UXO located at this site will be minimal.

\subsubsection{Rail Car Explosion Area}

The locations of inert UXO and fragments and several cracked open shells with base fuzes that are still in and around a crater within the Rail Car Explosion Area are shown in Figure 3-4. As with the NODA, the Rail Car Explosion Area site will be surveyed, both visually and using geophysical techniques, in accordance with relevant ICP specifications. Locations of potential UXO will be mapped and further investigated to verify the identification of the item. Once all UXO has been positively identified, the field team will retrieve the UXO in accordance with ICP procedures and transport the items to the MDA for disposal by high-order detonation.

As delineated in the OU 10-04 ROD (DOE-ID 2002), explosives (i.e., RDX) did not pose an unacceptable risk to human health or the environment at the Rail Car Explosion Area based upon the analytical results collected during the OU 10-04 RI/FS. Although explosives do not pose an unacceptable risk, it is reported that chunks of RDX are known to be present at the site. The RDX has been present at the site since the rail car explosion test was conducted in 1945 and does not degrade very rapidly under the environmental conditions present at the INL. However, the presence of RDX chunks at the site does pose a potential risk to human health if not handled properly.

To identify and flag (using conventional survey flags) all visible fragments of RDX, the site will be visually surveyed on foot by field crews. The RDX chunks will be retrieved by hand and placed in containers for shipment to the MDA for disposal by high-order detonation. To confirm that the RDX chunks have not degraded to an extent sufficient to adversely impact human health or the environment, soil samples will be collected and analyzed in accordance with the Field Sampling Plan for the Operable Units 6-05 and 10-04 Remedial Action, Phase IV (DOE-ID 2006a). Whether any excavation is required will depend on the analytical results as compared to the remediation goals, as outlined in the OU 10-04 ROD (DOE-ID 2002). 
As with the NODA, it is assumed that all UXO will be recoverable and transported to the MDA for disposal. In the event that a UXO item poses an unacceptable risk for recovery, the item will be disposed of by detonation in place. Soil that is potentially affected by in-place disposal of UXO will be sampled to assess the residual contamination resulting from the disposal activity. Should the soil prove to present an unacceptable risk to human health or the environment, the soil will be excavated by hand or with a small excavator to an initial depth of approximately $7.5 \mathrm{~cm}(3 \mathrm{in}$.$) . The excavated soil will be placed in$ containers or stockpiled at a single location on the site. Appropriate dust-suppression techniques will be used to minimize the generation of fugitive dust and to mitigate exposure of personnel to any airborne contamination.

Using field-screening methodology as specified in the Field Sampling Plan for the Operable Units 6-05 and 10-04 Remedial Action, Phase IV (DOE-ID 2006a), the soil at the bottom of the excavation will be analyzed for RDX. The field-screening method allows for near-real-time analyses with results available the same day. If the results are below the remediation goals defined in the OU 10-04 ROD (DOE-ID 2002), no further excavation will be required. If the result exceeds the remediation goal, another 7.5-cm (3-in.) lift will be performed, followed by reanalysis of the remaining soil. This iterative process will continue until the contaminant concentrations in the remaining soil are below the remediation goal. Soil stabilization techniques (e.g., use of water sprays, soil fixatives) will be employed to preclude erosion of the excavation area and prevent generation of fugitive dust that may entrain contamination.

Geophysical screening with an all-metal detector will be used to confirm that no additional items are present below the bottom of the last lift. These results will be recorded in the field logbook along with the result of the analytical screening and any observations of soil conditions indicating that native soil has been reached or indicating that any observed staining or other visual evidence of contamination has been removed.

If excavation is required, sampling of the affected soil will be performed in accordance with the Field Sampling Plan for the Operable Units 6-05 and 10-04 Remedial Action, Phase IV

(DOE-ID 2006a). Based on the results of the confirmatory sampling, additional excavation may be required. Once it is confirmed that the remediation goals have been achieved, the excavated area will be contoured to match the surrounding terrain and revegetated, as necessary.

The excavated soil will be characterized, as necessary, to ensure compliance with the Waste Acceptance Criteria for the selected disposal facility (e.g., the ICDF). If the summed concentrations of the analytes detected by SW-846 Method 8330 (EPA 2002) in the excavated soil exceed 10,000 mg/kg, the soil will be transported to a permitted RCRA treatment, storage, and disposal facility for thermal treatment and disposal.

\subsubsection{Land Mine Fuze Burn Area}

As shown in Figure 3-5, inert UXO and fragments along with a number of fuzes comprising UXO are located at the Land Mine Fuze Burn Area. The approach for remediation of the Land Mine Fuze Burn Area will be similar to that outlined for the NODA. Based upon historical results of previous interim actions conducted at the Land Mine Fuze Burn Area, it is anticipated that the primary UXO located at this site will be comprised of fuzes. 


$$
\text { 3-18 }
$$




\section{HUMAN HEALTH AND ENVIRONMENTAL COMPLIANCE}

\subsection{Remedial Action Objectives}

Phase IV primarily addresses UXO-contaminated sites; although, the potential exists for explosive-contaminated soil to be encountered during the Phase IV activities attributed to the disposal activities that were conducted during the remediation of UXO and TNT/RDX-contaminated sites. Therefore, RAOs are provided both for the UXO and the TNT/RDX.

\subsubsection{Unexploded Ordnance Contaminated Sites}

The RAOs for the ordnance areas were developed in accordance with the NCP (40 CFR 300) and EPA guidance (EPA 1988) and through the consensus of DOE-ID, EPA, and Idaho DEQ participants. The RAOs are based on the results of both the human health risk assessments and ecological risk assessments and are specific to the contaminants of concern and exposure pathways developed for OU 10-04.

The RAOs specified for protecting human health are expressed both in terms of risk and exposure pathways, because protection can be achieved through reducing contaminant levels as well as through restricting or eliminating exposure pathways. UXO does not have a typical exposure pathway where the overall intent of the human health RAOs is to limit the cumulative carcinogenic human health risk to less than or equal to 1E-04, and noncarcinogenic exposure to less than or equal to a hazard quotient of 1. Therefore, the UXO at the ordnance areas was excluded from quantitative analysis in the baseline risk assessment. However, the potential UXO at these areas presents an unacceptable risk of acute physical injury from fire or explosion resulting from accidental or unintentional detonation. Therefore, an RAO pertaining to the explosive safety aspect of ordnance to eliminate or reduce the potential for exposure to explosive ordnance was developed. The RAO developed for the ordnance areas to protect human health is as follows:

- $\quad$ Prevent any inadvertent contact with potential UXO by on-Site workers and members of the public.

\subsubsection{Explosive-Contaminated Soil}

Phase IV also addresses any residual explosive-contaminated soil resulting from the disposal of UXO by high-order detonation either in place or at the MDA. Additionally, the MDA will require assessment following the completion of all TNT/RDX and UXO remediation activities at other sites wherein the TNT/RDX and UXO have been disposed of at the MDA. Depending on the results of this assessment of the MDA or in-place disposal locations, remediation of contaminated soil may be required. Therefore, RAOs developed for TNT/RDX-contaminated sites will apply to soil contaminated as a result of the disposal activities. These RAOs are based on the results of both the human health risk assessments and the ecological risk assessments and are specific to the identified contaminants of concern.

The conclusions from the remedial investigation/baseline risk assessment that were used to develop the RAOs for TNT/RDX-contaminated soil are summarized below:

- Ingestion of homegrown produce, dermal adsorption of soil, ingestion of soil, and ingestion of groundwater are the only human health exposure routes with unacceptable estimated risks for the TNT/RDX-contaminated soil. 
- $\quad$ Risks associated with the air pathway are well below 1E-04; therefore, RAOs for the air pathway are not required. (Note: Appropriate safety measures, as determined by air emissions calculations, will be implemented during remedial actions to ensure that dust emissions do not exceed the limits specified by ARARs.)

The RAOs specified for protecting human health are expressed both in terms of risk and exposure pathways, because protection can be achieved through reducing contaminant levels as well as through restricting or eliminating exposure pathways. The overall intent of the human health RAOs is to limit the cumulative carcinogenic human health risk to less than or equal to 1E-04 and noncarcinogenic exposure to less than or equal to a hazard quotient of 1 . The RAOs specified for protecting ecological receptors inhibit adverse effects from contaminated soil on resident populations of flora and fauna. The RAOs developed to protect human health and ecological receptors are as follows:

- Inhibit dermal exposure to and ingestion of contaminated soil and food crops with a total excess cancer risk level of greater than 1E-04 and noncarcinogenic contaminants of concern with hazard quotients greater than 1 for current and future workers and future residents.

- $\quad$ Prevent contamination of groundwater.

- Inhibit ecological receptor exposures to soil contaminated with contaminants of concern, primarily exposure to soil concentrations that result in a hazard quotient greater than or equal to 10.0. The RAO excludes naturally occurring elements and compounds that are not attributable to historic releases.

- Inhibit any inadvertent contact with potential UXO by on-Site workers and members of the public, since potential UXO exists at these areas.

Remediation goals were established to meet these objectives. The remediation goals for the explosive-contaminated soil are provided in Table 4-1. These goals are at the upper end of the acceptable risk range because of the conservatism used in the risk assessment methods used to develop these values. By cleaning up to the identified contaminant concentration, remediation goals can be satisfied. Removing the principal threat waste types (TNT and RDX) will be protective, because surface exposure will be reduced or eliminated and will reduce the potential groundwater risk.

Table 4-1. Remediation goals for Operable Unit 10-04 contaminated soil.

\begin{tabular}{lc} 
Potential Contaminant of Concern & $\begin{array}{c}\text { Remediation Goal } \\
(\mathrm{mg} / \mathrm{kg})\end{array}$ \\
\hline Trinitrotoluene & 16.0 \\
Royal Demolition Explosive & 4.4 \\
1,3-Dinitrobenzene & 6.1 \\
\hline a. The EPA Region 9 (EPA 2004) human health preliminary remediation goals were selected \\
as the soil concentration remediation goals for explosive-contaminated soil because these \\
values are protective of both human health and ecological receptors. The remediation goals \\
are based upon the residential soil direct-contact exposure pathway concentrations. The EPA \\
soil screening-level guidance for ecological receptors fell below the Region 9 preliminary \\
remediation goal for all contaminants. \\
EPA = Environmental Protection Agency.
\end{tabular}




\subsection{Applicable or Relevant and Appropriate Requirements}

Table 4-2 summarizes how the substantive requirements of the ARARs and the to-be-considered requirements for the OU 10-04 Phase IV contaminated sites have been addressed by the remedial design or will be addressed during the remedial action. The substantive requirements of the RCRA and IDAPA ARARs specific to hazardous waste will be met for those media where RCRA hazardous constituents might be present. These requirements are not applicable to those media that are not RCRA hazardous. The chemical-specific ARAR listed is applicable in the case that explosive-contaminated soil requires remediation but is not applicable for the remediation of the UXO sites. Use of air monitoring and dust-suppression techniques during excavation will ensure compliance with emission ARARs. The sites have been surveyed for cultural and archaeological resources (see Appendix D), and appropriate actions will be taken to satisfy ARARs for protection of sensitive resources. If cultural resources are encountered, the requirements delineated in the Idaho National Laboratory Cultural Resource Management Plan (DOE-ID 2005) will be invoked. The DOD Standard 6055.9 Chapter 12 requirements (DOD 2004) also will be met.

\subsection{Quality Assurance}

The "Hazard Assessment Document for the Removal and Detonation of Unexploded Ordnance at the INL Hazard Classification" (HAD-238) addresses this project's activities. Because there is no risk from radioactive material associated with this removal action, the facility and activity are categorized as less than Hazard Category 3 or radiological facility. DOE M 440.1-1A describes the DOE explosives safety requirements applicable to operations involving the development, testing, handling, and processing of explosives or assemblies containing explosives through the various life cycles of the facility. The INL Site ordnance activities will comply with institutional procedures for handling explosives and these procedures will comply with the requirements of DOE M 440.1-1A. Consideration will be given to U.S. military standards that are applicable to these ordnance-related activities. No further safety basis document will be written and DOE-ID approval is not required for the hazard assessment document. Because no safety structures, systems, and components have been identified that must function to prevent or mitigate the consequences of an accidental detonation, a safety category designation of "consumer grade" is appropriate for the remedial activities as defined in Management Control Procedure (MCP) -540, "Assigning Quality Levels," except as noted in the CH2M-WG Idaho, LLC, Quality Assurance Program.

The "Project Execution Plan for the Miscellaneous Sites Cleanup" (PLN-2087) has been adopted for this project and is incorporated by reference. This plan governs the functional and organizational activities that will be used for this project. The Quality Assurance Project Plan for Waste Area Groups 1, 2, 3, 4, 5, 6, 7, 10, and Removal Actions (DOE-ID 2006b) outlines the quality assurance/quality control (QA/QC) protocols for data and is adopted by reference for this project. The Field Sampling Plan for the Operable Units 6-05 and 10-04 Remedial Action, Phase IV (DOE-ID 2006a) describes the QA/QC requirements for field sampling and analysis of field survey samples. In addition, and where applicable, ICP technical specifications will specify QA/QC procedures for the given task, consistent with guidance provided by PLN-2087. 
Table 4-2. Compliance with applicable or relevant and appropriate requirements and to-be-considered guidance for the Phase IV remedial action.

\section{Category Citation \\ Title}

Chemical-Specific ARARs

Idaho Ground Water

Quality Rule

\section{Action-Specific ARARs}

Rules for the Control of

Air Pollution in Idaho

Resource Conservation and Recovery Act -

Standards Applicable to

Generators of Hazardous

Waste

Resource Conservation and Recovery Act -

Standards Applicable to

Owners and Operators

of Hazardous Waste

Treatment, Storage, and

Disposal Units

"Ground Water Quality

Standards,"

IDAPA 58.01.11.200
The TNT/RDX leaching from the site must not adversely affect groundwater quality. Standards for groundwater quality must be met.
"Fugitive Dust,"

IDAPA 58.01.01.650 and

.651

Reason

Relevancy $^{\mathrm{a}}$

Compliance Strategy

A Remediation of explosive-contaminated soil will be performed in accordance with the requirements set forth in this $\mathrm{RD} / \mathrm{RA}$ Work

Plan. Monitoring of groundwater quality at the INL has historically been performed under the purview of OU 10-08 with no analytes of concern detected.

Requires control of dust during excavation for recovery of UXO and other potential ordnance items. Dust shall be controlled at all times during excavation of explosive-contaminated soil.

"Hazardous Waste Determination,'

IDAPA 58.01.05.006

(40 CFR 262.11)

"General Facility

Standards for Owners and

Operators of Remediation

Waste Management

Sites,"

IDAPA 58.01.05.008

(40 CFR 264.1[j][1-13])
A RCRA hazardous waste determination is required for recovered UXO and other potential ordnance items, explosive fragments, excavated soil, and any secondary waste generated during remediation, which is to be treated or disposed of on or off the INL.

General RCRA treatment, storage, and disposal facility standards must be met during remediation.
Dust suppression measures will be implemented, as necessary, during the remedial action to minimize the generation of fugitive dust. These measures keeping vehicle speeds to a minimum, use of soil fixatives, and work controls during periods of high wind.

A hazardous waste determination will be developed based on an evaluation of sampling data and process knowledge to determine disposition of the waste.

Assessment of remediation waste will be performed in accordance with RCRA requirements. The INL Site controls will prevent unauthorized access. Training will be conducted in accordance with the project Health and Safety Plan (HASP) (PLN-2128). may include water sprays, use of tarps, 
Table 4-2. (continued).

\begin{tabular}{|c|c|c|c|c|}
\hline Category & Citation & Reason & Relevancy $^{\mathrm{a}}$ & Compliance Strategy \\
\hline & $\begin{array}{l}\text { "Equipment } \\
\text { Decontamination," } \\
\text { IDAPA 58.01.05.008 } \\
\text { (40 CFR 264.114) }\end{array}$ & $\begin{array}{l}\text { All equipment used during } \\
\text { remediation that contacts hazardous } \\
\text { waste must be decontaminated in } \\
\text { accordance with the substantive } \\
\text { RCRA requirements. }\end{array}$ & A & $\begin{array}{l}\text { Equipment decontamination will be } \\
\text { conducted in accordance with the project } \\
\text { HASP (PLN-2128), waste management } \\
\text { procedures outlined in this RD/RA Work } \\
\text { Plan (Appendix B), and the INL "Pollution } \\
\text { Prevention Plan" (program description } \\
\text { document [PDD] -1029). }\end{array}$ \\
\hline & $\begin{array}{l}\text { "Use and Management of } \\
\text { Containers," } \\
\text { IDAPA 58.01.05.008 } \\
\text { (40 CFR 264.171-177) }\end{array}$ & $\begin{array}{l}\text { Hazardous waste generated during } \\
\text { remediation that is managed in } \\
\text { containers must meet the } \\
\text { substantive RCRA requirements. }\end{array}$ & A & $\begin{array}{l}\text { The waste management procedures outlined } \\
\text { in this RD/RA Work Plan (Appendix B) } \\
\text { ensure that waste is compatible with the } \\
\text { container and container integrity is } \\
\text { maintained. Weekly inspections will be } \\
\text { conducted by Waste Generator Services. } \\
\text { Secondary containment for all containers } \\
\text { with free liquids will be provided at the } \\
\text { CERCLA storage area. }\end{array}$ \\
\hline & $\begin{array}{l}\text { “Open Burning; Waste } \\
\text { Explosives," } \\
\text { IDAPA 58.01.05.008 } \\
\text { (40 CFR 265.382) }\end{array}$ & $\begin{array}{l}\text { Detonation of UXO, other explosive } \\
\text { ordnance items, and TNT/RDX } \\
\text { fragments must be performed in a } \\
\text { manner that does not threaten } \\
\text { human health or the environment. }\end{array}$ & A & $\begin{array}{l}\text { Detonation of UXO, other explosive } \\
\text { ordnance items, and TNT/RDX will be } \\
\text { performed in accordance with approved } \\
\text { procedures. Job safety analyses will be } \\
\text { prepared, reviewed, and approved by } \\
\text { subject-matter experts. Detonations will be } \\
\text { performed by EOD experts. }\end{array}$ \\
\hline $\begin{array}{l}\text { Resource Conservation } \\
\text { and Recovery Act - } \\
\text { Standards for the } \\
\text { Management of Specific } \\
\text { Hazardous Wastes and } \\
\text { Specific Types of } \\
\text { Hazardous Waste } \\
\text { Management Facilities }\end{array}$ & $\begin{array}{l}\text { "Military Munitions } \\
\text { Rule," } \\
40 \text { CFR } 266.205 \text { and } .206\end{array}$ & $\begin{array}{l}\text { Recovered UXO, other ordnance } \\
\text { items, and TNT/RDX fragments } \\
\text { identified as hazardous waste under } \\
\text { RCRA must meet the substantive } \\
\text { RCRA requirements for storage, if } \\
\text { required during remediation on an } \\
\text { interim basis, and transport. Any } \\
\text { emergency response conducted } \\
\text { during remediation involving } \\
\text { munitions or explosives will be } \\
\text { exempt from RCRA waste } \\
\text { generator and transporter } \\
\text { requirements. }\end{array}$ & A & $\begin{array}{l}\text { The UXO, other ordnance items, and } \\
\text { TNT/RDX fragments identified as hazardous } \\
\text { waste under RCRA will be handled and } \\
\text { stored in accordance with this work plan. In } \\
\text { accordance with } 40 \text { CFR } 266.202 \text { (a), a } \\
\text { military munition is not a solid waste when } \\
\text { (1) used for its intended purpose including: } \\
\text { (iii) Recovery, collection, and on-range } \\
\text { destruction of UXO and munition fragments } \\
\text { during range clearance activities at active or } \\
\text { inactive ranges. Therefore, it is anticipated } \\
\text { that the majority of UXO will not be } \\
\text { considered hazardous waste under RCRA. }\end{array}$ \\
\hline
\end{tabular}


Table 4-2. (continued).

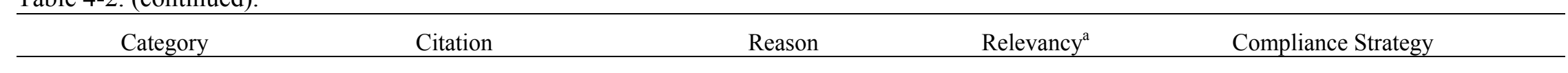

\section{Location-Specific ARARs}

National Historic

Preservation Act

Protection and

Repatriation Act

"Historic Properties

Owned or Controlled by

Federal Agencies,"

16 USC 470 h-2

"Identification of Historic

Properties,"

36 CFR 800.4

"Assessment of Adverse

Effects,"

36 CFR 800.5

"Custody,"

25 USC 3002

(43 CFR 10.6)

"Repatriation,"

25 USC 3005

(43 CFR 10.10)
In accordance with federal

requirements, the site must be

surveyed for cultural and

archaeological resources before

construction, and appropriate

actions must be taken to protect any

sensitive resources.

In accordance with federal requirements, the site must be surveyed for cultural and archaeological resources before construction, and appropriate actions must be taken to protect any sensitive resources.
Cultural and archaeological resource surveys have been performed. A summary of the results of the surveys is provided in Appendix D. The surveys show that there are cultural and/or archaeological resources within the sites. Employees involved in remediation activities at the sites will be trained in archaeological awareness. When cultural and/or archaeological resources are encountered, measures will be taken to mitigate the impact that the remediation activities have on those resources.

\section{Cultural and archaeological resource surveys} have been performed. A summary of the results of the surveys is provided in Appendix D. The surveys show that there are cultural and/or archaeological resources within the sites.

Employees involved in remediation activities at the sites will be trained in archaeological awareness. When cultural and/or archaeological resources are encountered, measures will be taken to mitigate the impact that the remediation activities have on those resources. 
Table 4-2. (continued).

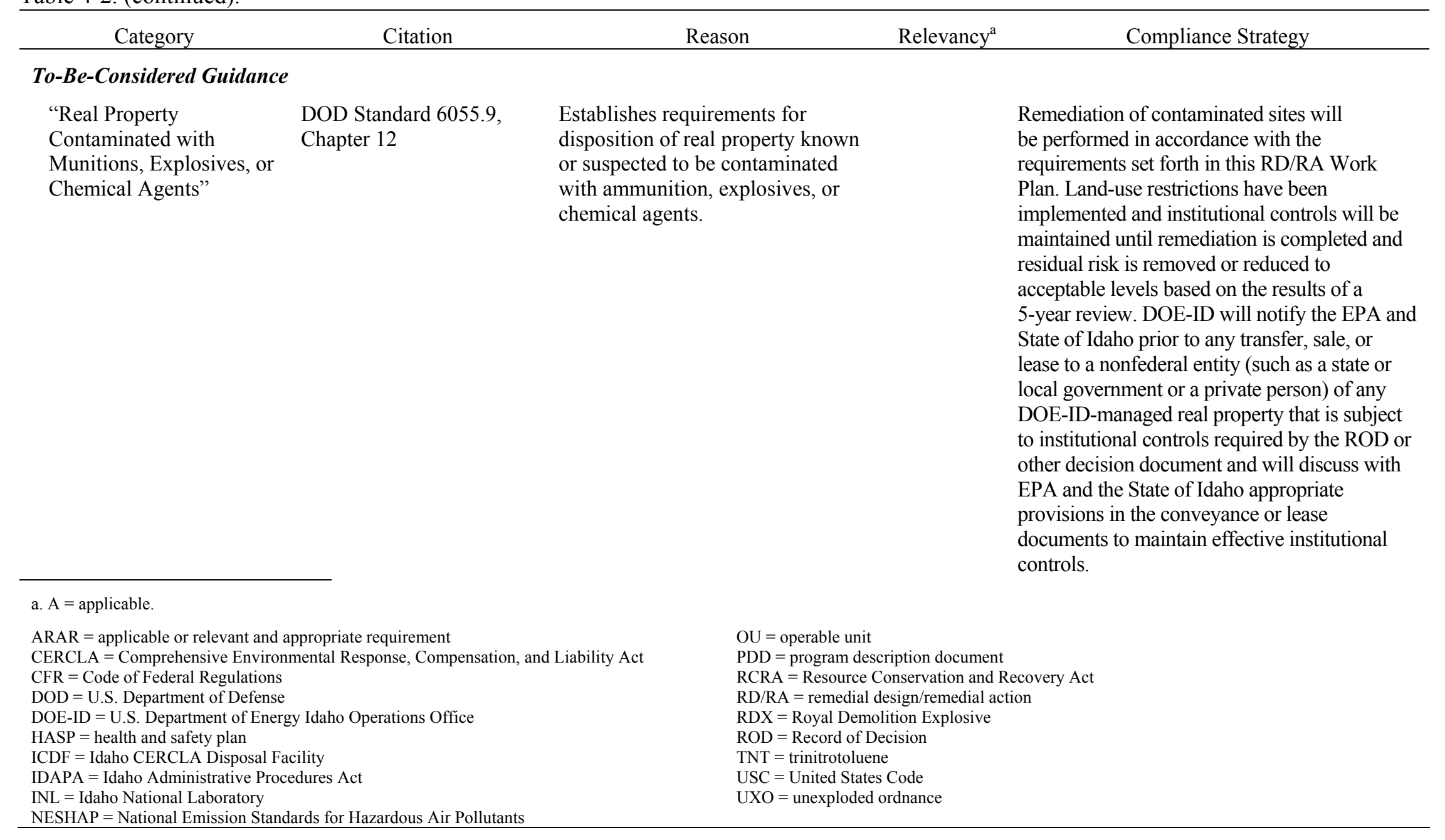




\section{REMEDIAL ACTION WORK PLAN}

This section details the management approach to the remedial action, including schedule and the necessary steps and documentation to perform the remedial action and document its completion. This section describes the elements necessary to implement the remedial design outlined in Sections 1-4. Because the remedial design and the remedial action work plan are combined into one document (i.e., this report), some details of implementation have been described in the design portion of this document for clarity.

\subsection{Work Tasks}

For the purposes of this RD/RA Work Plan, "contractor" refers to the current O\&M contractor. "subcontractor" means the business entity contracted to provide the materials, supplies, and/or services discussed herein. The following subsections summarize the primary work tasks critical to completing the activities specified in this RD/RA Work Plan.

\subsubsection{Site Preparation}

Plot plans delineating the lay-down areas shall be prepared before field activities commence. A summary of planned activities for each site is provided in Section 3.5.

\subsubsection{Task-Site Staging}

A lay-down area will be necessary at each task site to stage equipment and materials close to the work. The staging area shall be located so that noncontaminated materials and equipment operate in work areas isolated from contaminated materials and equipment. A temporary decontamination area for personnel and equipment shall be established at the control point for the area in accordance with the decontamination requirements of the project HASP (PLN-2128). Spill prevention and control shall be maintained for the lay-down area. The lay-down area shall be selected based upon several factors. Meteorological data shall be considered to ensure that the lay-down area is not located in an area downwind from the prevalent wind direction at the task site. Included among the other considerations for selecting the lay-down area at the task site will be the proximity to the area believed to require the greatest amount of excavation work, selection of a clean area based upon health and safety considerations, available infrastructure (e.g., power), and the topography of the site (e.g., undulating vs. flat). The combination of criteria will form the basis for selecting the staging area. Following the completion of all field activities, the task-site staging area shall be reclaimed in accordance with the construction specifications for earthwork and revegetation.

\subsubsection{Premobilization}

The contractor's Construction Management personnel assigned to this project will provide all required work orders. All contractor and subcontractor required training and current medical examinations and information required by the project HASP shall be provided prior to mobilizing to the task site. 


\subsubsection{Mobilization}

Mobilization describes the tasks that must be performed to prepare for field operations. These tasks are generally the required administrative, engineering, and health and safety controls that must be implemented prior to the commencement of field activities and include, but are not limited to, the following:

- $\quad$ Emplacing required fences, signs, and postings

- $\quad$ Identifying and demarking task sites

- $\quad$ Delivering and storing required material and equipment

- $\quad$ Setting up the site offices for field operations (as required)

- $\quad$ Establishing the required lay-down areas

- $\quad$ Establishing the required decontamination areas.

\subsubsection{Surface Water}

Contouring and grading backfilled areas shall be performed to maintain existing surface water flow patterns at the task site. Not all excavations will require backfilling, but areas shall be contoured for drainage and revegetated or otherwise stabilized. Revegetation of the backfilled excavations shall be performed to control the growth of noxious weeds.

\subsubsection{Geophysical Investigation}

Geophysical surveys will be conducted over each site to identify potential UXO. Anomalies detected from the surveys will be noted and further investigated to determine whether suspect items are present that require removal.

A geophysical survey using the magnetometer will be conducted over each site to identify potential UXO lying under the surface. Surveys will be performed by INL personnel and will encompass the entire area within the boundary for each site. For example, the UXO survey boundary as shown in Figure 3-1 for the NODA encompasses the locations of known live and former live UXO locations. Areas that had been previously assessed or cleared will be included in the survey to ensure that no UXO was missed during previous actions. Historically, UXO recovered at the site has been found on or near the surface. Historical activities resulting in UXO contamination at the site would primarily result in surface or near-surface deposition of UXO. Although the primary concern is surface or near-surface UXO, the geophysical instrumentation used will detect anomalies down to $3 \mathrm{~m}(10 \mathrm{ft})$. As the surveys progress, if anomalies are found at or beyond the defined boundary, the boundary will be expanded in accordance with resident specifications to ensure that all anomalies are identified.

Anomalies detected from the surveys will be mapped and further investigated to assess the validity of the initial identification and the risk associated with the potential UXO prior to any intrusive removal of the item. As previously stated, historically the UXO recovered at the INL has been located on or near the surface. To aid in the recovery of UXO that may be below the surface and cannot be visually located, hand-held metal detectors such as a Schonstedt Magnetic Location Model \#GA-52CX (or equivalent) will be used to sweep the area to locate anomalies identified during the geophysical survey. If a positive identification is received using the instrument, the item will be exposed via hand excavation and identified as to whether it is a metal fragment or ordnance. 
Some areas present topographic challenges that preclude totally surveying the area by the prescribed geophysical method. For example, the Big Lost River runs through sites such as the NODA and the Rail Car Explosion Area and does not allow for a full survey of the river bank and bottom using the towed geophysical survey array. In cases such as that presented by the Big Lost River, a White's metal detector will be used in conjunction with a geographical positioning system to survey those areas that cannot be accessed by the towed array. The data obtained using the White's metal detector will be combined with that from the array to ensure that the area is surveyed to the extent practicable. There is the possibility that some challenges may present themselves that cannot be overcome using the available detection techniques. These cases will be discussed on an individual basis with concurrence from the Agencies as they are encountered.

\subsubsection{Recovery and Disposal of Unexploded Ordnance}

Recovery of UXO items that are encountered during remediation of contaminated sites shall be under the direction of an EOD expert. The recovery, transportation, and disposal of UXO shall be performed using currently accepted practices and INL-specific procedures. All personnel participating in the recovery, transport, and disposal of UXO shall comply with the applicable requirements outlined in the project HASP.

Every item to be investigated shall be identified in terms of its type, size, and condition. The UXO shall be fully characterized using applicable technical manuals (including U.S. Department of Defense Joint Services Technical Manual-60 Series documents) and, if necessary, active EOD units and other EOD resources to identify the type, sensitivities, and hazards of ordnance. The EOD-qualified individual and explosive experts shall evaluate the condition of the UXO to determine whether it is safe to recover and transport the items for disposal.

The UXO will be removed, if safe to handle, transported to the MDA, and destroyed by high-order detonation using additional explosives to initiate the detonation. If the EOD expert or other health and safety professional determines that the items cannot be safely transported, the items shall be detonated in place after the proper documents have been prepared and approved. Given that high-order detonation will be used to dispose of all explosives during Phase IV activities, the quantity of explosive residues remaining at the site will be minimal. The potential contaminants of concern resulting from incomplete combustion will be assessed at the MDA following the remediation of the UXO sites to determine if the soil requires remediation. The MDA will remain under institutional control until remediation is performed following completion of the UXO remediation activities as part of the Phase IV cleanup.

\subsubsection{Recovery and Disposal of Explosive Fragments}

Recovery of explosive fragments that are encountered during remediation of contaminated sites shall be under the direction of a senior EOD officer. The recovery and transportation of fragments shall be performed using currently accepted practices and INL-specific procedures. All personnel participating in the recovery, transport, and disposal of explosive fragments shall comply with the applicable requirements outlined in the project HASP.

Every explosive item to be investigated shall be identified in terms of its type, size, and condition. The explosive items shall be fully characterized using applicable technical manuals (including U.S. Department of Defense Joint Services Technical Manual-60 Series documents) and, if necessary, active EOD units and other EOD resources to identify the type, sensitivities, and hazards of ordnance and explosives. The EOD-qualified individual and explosive experts shall evaluate the condition of the explosives to determine whether it is safe to recover and transport the items for disposal. 
Explosives will be removed, if safe to handle, transported to the MDA, and destroyed by high-order detonation using additional explosives to initiate the detonation. All disposal activities conducted at the MDA will be completed by the end of the day or the area secured should the activities fail to be performed. If the EOD expert or other health and safety professional determines that the items cannot be safely transported, the items shall be detonated in place after the proper documents have been prepared and approved. Given that high-order detonation will be used to dispose of all explosives during Phase IV activities, the quantity of explosive residues remaining at the site will be minimal. The potential contaminants of concern resulting from incomplete combustion will be assessed at the MDA following the remediation of the UXO sites to determine if the soil requires remediation. The MDA will remain under institutional control until remediation is performed following completion of the UXO remediation activities as part of the Phase IV cleanup.

\subsubsection{Clearing the Site}

Task sites requiring soil remediation shall be cleared of shrubs, vegetation, fences, and other debris in accordance with relevant ICP specifications. Because of the potential uptake of contamination, the vegetation will be collected along with the excavated soil for disposal in the ICDF.

Clearing operations shall be confined to the soil sites to be remediated, limited only to those areas requiring excavation, those areas required for barrier construction (required as needed to establish the task-site work zones in accordance with the project HASP), or as directed by INL project personnel. Any areas outside the designated areas that are damaged or disturbed by field operations shall be repaired and reseeded by the subcontractor in accordance with relevant ICP specifications.

\subsubsection{Soil Excavation and Consolidation}

Soil excavation shall be limited to only that soil necessary to remediate each task site requiring soil remediation. Excavated soil shall be consolidated, as necessary, in a designated area immediately adjacent to the task site. Consolidation will consist of temporarily stockpiling soil until it can be loaded into an appropriate container for transport to the ICDF for disposal. Stockpiling will be performed in accordance with the requirements delineated in the waste management plan provided in Appendix B. All excavation and consolidation activities shall be performed in accordance with relevant ICP specifications. To minimize the spread of contamination, equipment necessary for soil excavation shall remain within the contamination control zones until completion of excavation activities.

Precautions, such as water spray, use of tarps, keeping vehicle speeds to a minimum, use of soil fixatives, and work controls during periods of high wind, will be used as needed to prevent the generation of fugitive dust. Air monitoring to assess the airborne spread of contamination shall be performed in accordance with the project HASP. Air monitoring shall be conducted as needed to ensure that workers are protected from unnecessary exposure to chemical hazards. Personal protective equipment, when required, shall be used as specified in the project HASP and as determined by the industrial hygienist present at the task site.

\subsubsection{Earthwork}

The earthwork on this project will be defined as the following:

- $\quad$ Clearing vegetation as required. Vegetation is minimal and clearing may be accomplished concurrently with the excavation of contaminated soil. 
- $\quad$ Excavating all materials encountered, of every description, for completion of the project as described in relevant ICP specifications.

- $\quad$ Managing dust control.

- Delivering all contaminated material excavated for completion of the project to an on-Site disposal facility.

- $\quad$ Backfilling or contouring all excavations and reclaiming all disturbed task area support sites.

- $\quad$ Compacting all backfill in accordance with relevant ICP specifications.

- $\quad$ Finish grading and grading for surface drainage or revegetation in accordance with relevant ICP specifications.

Earthwork at each of the task sites will include backfill with native soil from approved borrow sources on the INL, as required. All earthwork will be performed in accordance with relevant ICP specifications.

\subsubsection{Borrow, Haul, and Stockpile}

Borrow materials that may be required for this project are available from borrow sources located at the INL. All on-Site borrow sources have previously been determined to be free of contamination. Borrow operations will be performed in accordance with relevant ICP specifications and an approved ICP Form 450.AP01, "INEEL Gravel/Borrow Source Request Form." An operation shall be established at the borrow area to gather and stockpile the material in preparation for a hauling operation to move the material from the borrow source to the project site for emplacement.

Equipment used for the haul and stockpile operations shall remain outside the contamination work areas. The work will require the services of heavy earthwork equipment such as scrapers, dozers, loaders, and large dump trucks. The work also will require up-front planning and coordination with other Site operations and personnel to ensure safe and productive hauling across Site roads. The subcontractor shall be responsible for maintaining the Site haul roads during operations and for returning haul roads to their original condition. A traffic management plan shall be prepared, including documentation of the condition of the haul roads prior to operations.

\subsubsection{Contaminated Soil Hauling}

Contaminated soil will be hauled to the disposal facility in either end-dump trucks or roll-on/roll-off containers with an anticipated capacity of $9.2 \mathrm{~m}^{3}\left(12 \mathrm{yd}^{3}\right)$ or greater. It is anticipated that any soil generated will be transported in exclusive-use, closed-transport vehicles.

Hauling may occur concurrently from different locations, provided the buddy system remains in effect and the crew is large enough to support the operations, as determined by the field team leader, health and safety officer, and/or job site supervisor. Each dump truck or roll-on/roll-off container will have a locking tailgate with a gasket or another mechanism to prevent loss of soil during transport. The driver will inspect the tailgate before and after loading to ensure that it is properly latched. The dump truck or roll-on/roll-off container will have a new plastic liner installed for each load to mitigate spread of contamination and provide a means of dust control during transportation and disposal. Loads will be covered with a tight-fitting tarp to prevent loss of material during transport. The cover will be evaluated and approved by environmental personnel before initial use and throughout the duration of the project. 
After loading and before leaving the area, the driver will visually inspect each truck or roll-on/roll-off container to ensure that the exterior is not contaminated (e.g., presence of dirt). Before leaving the area and under the direction of the job site supervisor, any discovered external contamination will be removed. Dry decontamination methods will be employed whereby the dirt will be physically removed using brooms or comparable means until the external surface is visibly clean. If dry decontamination methods are not successful, wet decontamination methods will be implemented requiring the construction of a bermed decontamination pad and containerization and analysis of decontamination fluids for disposal. After the load has been dumped, the truck or roll-on/roll-off container will be covered with a tarp for the return trip.

\subsubsection{Dust Suppression}

Dust generation will be minimized during excavation, loading, hauling, and dumping by using water truck(s) and/or soil fixatives. Results of air monitoring, as directed by the industrial hygienist, will help determine whether the dust-suppression methods are adequate. Overapplication of water, resulting in free liquids, will not be allowed because additional requirements would be imposed for handling liquid waste. A water-fill station is available at the CFA and fire hydrants are available at other facilities, provided an outage request is processed. Filling at a fire hydrant requires using an attaching gate valve and fire hose approved by the project manager and/or designee to ensure compatibility.

Work will be restricted or suspended if unacceptable amounts of dust are being generated as determined by the field team leader and/or health and safety officer. Unacceptable amounts are determined through direct readings of particulates greater than $10 \mathrm{mg} / \mathrm{m}^{3}$ inhalable particles and $3 \mathrm{mg} / \mathrm{m}^{3}$ respirable particles (PLN-2128). This dust could be a result of dry soil (which might require wetting) or a result of wind. All excavating, loading, hauling, and dumping operations will be suspended when sustained wind speed or gusts, as reported by the INL NOAA weather station, exceed established levels. Typically, work will be evaluated if wind speeds exceed $25 \mathrm{mph}$ sustained with gusts exceeding $35 \mathrm{mph}$; however, this requirement may be adjusted as directed by the field team leader and/or health and safety officer. Partial or full days are anticipated to be lost because of high wind. Work areas that have the potential of generating dust will require water spraying at the end of each workday and other occasions as deemed necessary by the field team leader and/or health and safety officer.

\subsubsection{Reclamation Seeding}

Upon completion of all earthwork activities, reclamation seeding will take place on the lay-down area and all areas affected by the remediation activities, including material borrowing and stockpiling. The seeding and mulching of these sites will be performed in accordance with the requirements delineated in relevant ICP specifications.

\subsubsection{Demobilization}

After the remedial action activities have been satisfactorily completed and all equipment has been properly decontaminated, task-site personnel will demobilize and the equipment will be removed from the site. Decontamination pads and temporary fencing erected in support of the activities described herein will be removed and packaged or disposed of appropriately. 


\subsection{Field Oversight}

The DOE-ID remediation project manager will be responsible for notifying the EPA and DEQ about project activities. The project manager also will serve as the single interface point for all routine contact between the Agencies and the contractor. The contractor will provide support services for field oversight, health and safety, environmental, quality assurance, and landlord services for this project. An organization chart and position descriptions are provided in the project HASP (PLN-2128).

\subsubsection{Protocol and Coordination of Field Oversight}

DOE-ID will notify the EPA and DEQ WAG managers of pending remedial action activities (such as project startup, closeout, and inspections). Activities related to preliminary inspections, the prefinal inspection, and the final inspection (if deemed necessary) will be provided to the EPA and DEQ WAG managers a minimum of 14 calendar days prior to commencement of the activity.

Visitors to any of the project sites who wish to observe activities must meet badging and training requirements necessary to enter INL facilities. Training requirements for visitors are described in the project HASP (PLN-2128).

\subsection{Project Cost Estimate}

Table 5-1 presents the project cost estimates for the tasks addressed by this Phase IV RD/RA Work Plan. The costs may be revised during subsequent submittals of this document to reflect the most current estimate, based on comments regarding the design and other data.

\subsection{Project Schedule}

The schedule for Phase IV of the OU 10-04 RD/RA is presented in Table 5-2. The schedule covers all Phase IV project tasks identified in the OU 10-04 RD/RA Scope of Work (DOE-ID 2003) through completion of the Phase IV remedial action report. Administrative and document preparation activities are based upon an 8-hour day, 5-day workweek, while field activities are based upon a 10-hour day, 4-day workweek. The schedule does not include any contingency for delay because of late or slow document reviews or for field activities experiencing loss of productivity because of adverse weather conditions or other causes outside the project team's control.

\subsection{Inspections}

Periodic inspections can occur at any time during the remediation activities. Upon completion of remediation activities but prior to demobilization, a standard prefinal inspection will be performed at the site at the discretion of the project managers or designees. The prefinal inspection may be performed prior to revegetation of the sites given that completion of all other remediation activities (i.e., excavation, contouring, and sampling) may occur prior to the specified timeframes for reseeding. The prefinal inspection will be conducted to document the status of all project work elements. If determined to be necessary by concurrence of the Agencies, a final inspection may be performed to assess whether deficiencies identified during the prefinal inspection have been addressed adequately. The inspections will establish compliance with this RD/RA Work Plan and all requirements indicated. 
Table 5-1. Phase IV project cost estimate.

\begin{tabular}{|c|c|c|}
\hline Description & $\begin{array}{c}\text { Cost }(\$) \\
\text { (Net Present Value) }\end{array}$ & $\begin{array}{c}\text { Totals } \\
(\$)\end{array}$ \\
\hline Capital Costs & & 859,100 \\
\hline Remedial Design/Remedial Action Statement of Work & 11,000 & \\
\hline Remedial Design/Remedial Action Work Plan & 97,200 & \\
\hline Hazards and safety analysis documentation & 11,500 & \\
\hline Sampling and Analysis Plan & 4,100 & \\
\hline Health and Safety Plan & 3,100 & \\
\hline Waste Management Plan & 1,900 & \\
\hline Miscellaneous environmental documentation & $\underline{6,300}$ & \\
\hline Remedial Design & $\underline{\underline{135,100}}$ & \\
\hline Quality assurance & 20,100 & \\
\hline Project office operations & $\underline{47,500}$ & \\
\hline Remediation Support & $\underline{\underline{67,600}}$ & \\
\hline Engineering and technical support & $\underline{112,900}$ & \\
\hline Remediation/Technical Support Activities & $\underline{\underline{112,900}}$ & \\
\hline Mobilization and preparatory work & 60,700 & \\
\hline Site work & 375,600 & \\
\hline Site restoration & 8,100 & \\
\hline Demobilization & 11,300 & \\
\hline Other & $\underline{15,500}$ & \\
\hline Remedial Action & $\underline{\underline{471,200}}$ & \\
\hline Prefinal Inspection & 1,700 & \\
\hline Remedial Action Report & $\underline{70,600}$ & \\
\hline Reporting & $\underline{\underline{72,300}}$ & \\
\hline Operations Cost $\mathrm{t}^{\mathrm{a}}$ & & $\underline{2,074,000}$ \\
\hline SUBTOTAL COSTS & & $2,933,100$ \\
\hline Plus $30 \%$ contingency & & $\underline{879,900}$ \\
\hline TOTAL PROJECT COST IN NET PRESENT VALUE & & $\underline{\underline{3,813,000}}$ \\
\hline \multicolumn{3}{|c|}{$\begin{array}{l}\text { Note: Net present value is the cumulative worth of all costs, as of the beginning of the first year of activities (i.e., FY 2004), accounting for } \\
\text { inflation of future costs. Net present values are estimated assuming variable annual inflation factors for the first } 10 \text { years - in accordance with } \\
\text { DOE Order 430.1B, "Real Property Asset Management"- followed by a constant } 5 \% \text { annual inflation rate. A constant } 5 \% \text { discount rate is } \\
\text { assumed. }\end{array}$} \\
\hline \multicolumn{3}{|c|}{$\begin{array}{l}\text { a. The operations cost reflected here is attributed to the operations and maintenance costs associated with the Phase I operations and } \\
\text { maintenance activities. }\end{array}$} \\
\hline $\begin{array}{l}\text { DOE = U.S. Department of Energy } \\
\text { FY = fiscal year }\end{array}$ & & \\
\hline
\end{tabular}


Table 5-2. Remedial action schedule.

\begin{tabular}{lccc}
\hline \multicolumn{1}{c}{ Activity } & Start Date & $\begin{array}{c}\text { Completion } \\
\text { Date }\end{array}$ & $\begin{array}{c}\text { Enforceable } \\
\text { Date }\end{array}$ \\
\hline Draft RD/RA Scope of Work sent to Agencies for review & $10 / 1 / 2002$ & $11 / 10 / 2002$ & \\
RD/RA Scope of Work finalized & $11 / 10 / 2002$ & $1 / 27 / 2003$ & \\
Draft Phase IV RD/RA Work Plan prepared & $10 / 1 / 2005$ & $5 / 31 / 2006$ & $7 / 31 / 2006$ \\
Agency review of the Draft Phase IV RD/RA Work Plan & $6 / 1 / 2006$ & $7 / 15 / 2006$ & \\
Agency comments on Draft Phase IV RD/RA Work Plan due & & $7 / 15 / 2006$ & \\
Resolution of Draft Phase IV RD/RA Work Plan comments & $7 / 16 / 2006$ & $8 / 30 / 2006$ & \\
Draft Final Phase IV RD/RA Work Plan sent to Agencies & $8 / 31 / 2006$ & $9 / 30 / 2006$ & \\
Phase IV RD/RA Work Plan finalized & & $10 / 14 / 2006$ & \\
Phase IV Remedial Action & & & \\
Phase IV Prefinal Inspection & $5 / 2 / 2007$ & $9 / 30 / 2011$ & \\
Draft Phase IV Remedial Action Report prepared & $9 / 16 / 2011$ & $9 / 30 / 2011$ \\
Agency review of the Draft Phase IV Remedial Action Report & $5 / 17 / 2012$ & $6 / 29 / 2012$ \\
$\begin{array}{l}\text { Agency comments on the Draft Phase IV Remedial Action } \\
\text { Report due }\end{array}$ & & $6 / 29 / 2012$ \\
$\begin{array}{l}\text { Resolution of Draft Phase IV Remedial Action Report } \\
\text { comments }\end{array}$ & $7 / 2 / 2012$ & $8 / 15 / 2012$ \\
$\begin{array}{l}\text { Draft Final Phase II Remedial Action Report sent to Agencies } \\
\text { Phase IV Remedial Action Report finalized }\end{array}$ & $8 / 16 / 2012$ & $9 / 13 / 2012$ \\
\hline $\begin{array}{l}\text { a. An allowance will be made for shutdown of field activities during the winter months. } \\
\text { RD/RA = remedial design/remedial action }\end{array}$ & $9 / 14 / 2012$ & $9 / 28 / 2012$ & $9 / 30 / 2020$ \\
\hline
\end{tabular}

\subsubsection{Prefinal Inspection}

The Agency project managers or their designees will conduct the prefinal inspection before completion of the remedial action. DOE-ID will notify the Agencies approximately 2 weeks before the prefinal inspection date. This inspection will determine the status of the remediation activities, including outstanding requirements and actions necessary to resolve any identified issues. During the inspection, the Agencies will identify and approve all of the outstanding requirements along with the actions required to resolve them. The prefinal inspection report will document any unresolved items and the actions required for resolution. In some instances, the prefinal inspections can be performed as each major element of the project is completed, rather than at the time of total completion.

A checklist used to document the prefinal inspection will be developed and implemented upon approval by the Agencies. The action for resolution and the anticipated schedule of completion will be noted next to the outstanding items and documented on the prefinal inspection checklist. 


\subsubsection{Prefinal Inspection Report}

Documentation of the prefinal inspection will be provided in a prefinal inspection report that will contain the following elements:

- The names of all inspection participants

- $\quad$ The inspection checklist(s) containing specific project elements and areas to be inspected to constitute acceptance of the remediation activities

- A discussion of all documented inspection findings

- Corrective actions to be taken to correct deficiencies identified in the inspections, including the required corrective action, acceptance criteria or standards, and planned dates for completion of the actions

- $\quad$ A date for the final inspection, if necessary.

The prefinal inspection report will be issued to indicate the objectives of the OU 10-04 ROD (DOE-ID 2002) are being met. The prefinal inspection report will not be revised/finalized. The inspection will be finalized in the remedial action report documenting the prefinal inspection process. The completed prefinal inspection checklist will be included as an appendix to the remedial action report in accordance with Section 8.4 of the Federal Facility Agreement and Consent Order for the Idaho National Engineering Laboratory (DOE-ID 1991). Submittal of the prefinal inspection report and the respective targeted schedule are identified in Table 5-2.

\subsubsection{Final Inspection}

If deemed necessary, the final inspection will be conducted following demobilization, after all excess materials and nonessential remediation equipment have been removed from the site and remediation of the site is considered complete. Some equipment may remain onsite to repair items identified during final inspections. Final inspections, as conducted by the Agencies' project managers or their designees, will confirm the resolution of all outstanding items identified in the prefinal inspection and verify that the OU 10-04 Phase IV remedial action has been completed in accordance with the requirements of the OU 10-04 ROD (DOE-ID 2002). Final inspections will be documented in the remedial action report.

\subsection{Remedial Action Sampling and Analysis Plan}

The remedial action sampling and analysis plan for Phase IV of the OU 10-04 RD/RA project is comprised of two parts: the Field Sampling Plan and the Quality Assurance Project Plan. These plans have been prepared pursuant to the NCP (40 CFR 300), consistent with the EPA policy on the preparation of sampling and analysis plans, and in accordance with internal company procedures. The Field Sampling Plan for the Operable Units 6-05 and 10-04 Remedial Action, Phase IV (DOE-ID 2006a) describes the field sampling activities that will be performed, while the Quality Assurance Project Plan details the process and programs that will be used to ensure that the data generated are suitable for their intended purposes. The governing Quality Assurance Project Plan for this sampling effort will be the Quality Assurance Project Plan for Waste Area Groups 1, 2, 3, 4, 5, 6, 7, 10, and Removal Actions (DOE-ID 2006b), which is incorporated into the Field Sampling Plan by reference. Work control processes will follow formal practices in accordance with communicated agreement with the appropriate site facility managers and the Miscellaneous Sites area manager. 


\subsection{Health and Safety Plan}

A HASP (PLN-2128) has been prepared that addresses projects being performed under the purview of the Miscellaneous Sites organization of CH2M-WG Idaho, LLC. The site-specific tasks and conditions anticipated to be encountered during the OU 10-04 Phase IV RD/RA activities have been incorporated into this plan. The HASP is a living document and may be updated as conditions dictate. The HASP covers the following items:

- $\quad$ Task-site responsibilities

- $\quad$ Personnel training

- Occupational Medical Program and medical surveillance requirements

- $\quad$ Accident Prevention Program

- $\quad$ Site control and security

- $\quad$ Hazard evaluation

- $\quad$ Personal protective equipment

- Decontamination

- $\quad$ Emergency response plan for the task sites.

\subsection{Waste Minimization Plan}

Waste will be generated as a result of the activities conducted during this project. The types of waste expected to be generated include, but are not limited to, the following:

- $\quad$ Personal protective equipment (PPE)

- Equipment decontamination liquid residue

- $\quad$ Equipment decontamination solid residue

- $\quad$ Plastic sheeting

- $\quad$ Excavated, contaminated soil

- $\quad$ Explosive fragments (to be detonated on the INL)

- $\quad \mathrm{UXO}$ (to be detonated on the INL)

- $\quad$ Removed vegetation to be disposed of with the excavated, contaminated soil

- $\quad$ Air monitoring filters

- Unused/unaltered sample material

- $\quad$ Analytical residues

- $\quad$ Sample containers

- $\quad$ Diesel fuel and hydraulic spills

- $\quad$ Miscellaneous waste. 
Waste could be hazardous. As remediation continues, additional waste streams could be identified. All waste streams are required to have the waste identified and characterized. The appropriate waste management organization (e.g., Waste Generator Services) will complete and approve hazardous waste determinations prior to or at the time of generation. A description of the types of waste anticipated to be generated and the proposed disposition route is provided in Appendix B, "Waste Management Plan."

\subsection{Decontamination Plan}

Equipment decontamination will be conducted at the task site where contaminated materials will be encountered. A decontamination area will be established such that the potential for downwind contamination from the remediation site is mitigated. Decontamination operations will be performed in accordance with the requirements set forth in the project HASP (PLN-2128).

Dry decontamination procedures will be used at the beginning of the decontamination effort. If these procedures are not successful, the equipment will be moved onto a clean decontamination pad or plastic and sprayed with a high-pressure water spray from a portable unit. The subcontractor will provide a design for the decontamination pad with approval of the contractor. All equipment will then be surveyed and visually inspected to ensure that all source contamination has been removed. If additional decontamination is required, further decontamination efforts will be conducted until the equipment is clean and may be released. The equipment will remain in the area where remediation is occurring until it is adequately decontaminated, as verified by field surveillance methods.

Management of waste generated during decontamination efforts will remain within the area of contamination for temporary storage until final waste disposition. Tools used for equipment decontamination will be decontaminated, surveyed for contamination, and released for reuse.

\subsection{Spill Prevention/Response Program}

Any inadvertent spill or release of potentially hazardous materials will be subject to the substantive requirements contained in "INL Emergency Plan/RCRA Contingency Plan" (PLN-114). Handling of the materials and/or substance will be performed in accordance with the recommendations of the applicable material safety data sheets, which will be located onsite. In the event of a spill, the emergency response plan (see Section 11 in the project HASP [PLN-2128]) will be activated. All materials/substances on the work site will be stored in accordance with the applicable regulations and in approved containers.

\subsection{Operations and Maintenance Plan}

The "Operations and Maintenance Plan for Operable Units 6-05 and 10-04, Phase IV" (provided in Appendix C) describes the long-term O\&M activities that will be conducted in support of the OU 10-04 Phase IV activities to ensure that the selected remedy identified in the OU 10-04 ROD (DOE-ID 2002) remains protective of human health and the environment. The plan outlines the ongoing maintenance activities and inspection requirements for the Phase IV remediated sites. The plan is a living document, revised as necessary to incorporate changes and additions identified during implementation of the plan. If contamination exceeding the allowable concentrations for free release remains following all efforts to remediate a site, the site will be placed under institutional control. This event will be documented in the final remedial action report.

The INL Sitewide Institutional Controls Plan (DOE-ID 2006c) outlines the institutional control requirements for INL CERCLA sites, including WAG 10. Land use will be restricted at all 
UXO-contaminated sites until remediation is implemented as prescribed in the OU 10-04 ROD (DOE-ID 2002); then, based on analysis of residual risk, potential land use will be determined. Land-use control will not be required after remediation if it can be demonstrated that all UXO fragments have been removed from a site and any contaminated soil exceeding the defined remediation goals (Table 4-1) has been removed. Remediation, however, may not be $100 \%$ effective, and buried, undetected UXO or explosive fragments may remain at the site. In addition, confirmation of complete UXO removal may not be possible in all locations, with complete UXO removal not being practical or feasible in some areas. As determined by postremediation risk analysis, land-use restrictions will be established and maintained as required for areas that potentially pose a threat from buried, undetected explosives or UXO. Institutional controls will be maintained until residual risk is removed or reduced to acceptable levels based on the results of a 5-year review. DOE-ID will notify EPA and the State of Idaho before any transfer, sale, or lease to a nonfederal entity (such as a state or local government or a private person) of any of the UXO-contaminated sites. These sites will be subject to 5-year reviews with restrictions remaining until 2095 or until determined to be unnecessary during the 5-year reviews.

\subsection{Remedial Action Report}

The Phase IV remedial action report will be prepared following demobilization and restoration of the sites and submitted to the Agencies as a primary document. The remedial action report will include, but not be limited to, the following:

- Identification of the work defined in this Phase IV RD/RA Work Plan and certification that the work was performed.

- A chronology of the remediation field activities.

- Explanation of any modifications to the Phase IV RD/RA Work Plan.

- Any modifications made to the remedial design during the remedial action phase, including the purpose and results of the modifications.

- $\quad$ Problems encountered during the remedial action and resolutions to these problems.

- $\quad$ Any outstanding items from the prefinal inspection checklist that were identified and described. In responding to comments received, the prefinal inspection checklist will not be revised; rather it will be finalized in the context of the remedial action report.

- Certification that the remedy is operational and functional. DOE-ID will provide a statement certifying that the remedies are achieving, or have achieved, the requirements of the OU 10-04 ROD (DOE-ID 2002).

- As-built drawings showing final contours.

- $\quad$ Final total costs of the remedial action for Phase IV activities.

- $\quad$ Results of the Phase IV final inspection(s), if required. Any final inspection will be documented in the draft remedial action report, submitted to the Agencies' project managers within 60 calendar days of the final inspection, and used to resolve prefinal inspection issues.

- A summary of the required O\&M activities following completion of the remedial action. 
5-14 


\section{FIVE-YEAR REVIEW}

In accordance with the NCP (40 CFR 300), a statutory review of the selected remedy will be conducted no less than every 5 years for sites where contamination above the risk-based concentrations is left in place. It is the intention of this project to remove contamination to levels below the risk-based concentrations, but, in the event that contamination above these concentrations remains at a given site, a 5 -year review will evaluate the remedy to determine if it remains protective of human health and the environment. Five-year reviews will be conducted for remediated sites with institutional controls until the year 2095 at a minimum (i.e., until the 100-year institutional control period expires) or until it is determined during a 5-year review that the controls and reviews are no longer necessary. Five-year reviews will include visual surveys of the institutionally controlled sites to assess the condition of the sites and determine whether any changes have occurred that would indicate whether additional remedial action is necessary. An INL Sitewide 5-year review was completed in 2005, and one is scheduled within 5 years of the completion of the last 5-year review report, which was in October 2005. 


\section{REFERENCES}

36 CFR 800.4, 2004, "Identification of Historic Properties," Code of Federal Regulations, Office of the Federal Register, August 9, 2004.

36 CFR 800.5, 2004, “Assessment of Adverse Effects," Code of Federal Regulations, Office of the Federal Register, August 9, 2004.

40 CFR 262.11, 2006, "Hazardous Waste Determination," Code of Federal Regulations, Office of the Federal Register, August 21, 2006.

40 CFR 264.1, 2006, "Purpose, Scope, and Applicability," Code of Federal Regulations, Office of the Federal Register, July 14, 2006.

40 CFR 264.114, 2006, "Disposal or Decontamination of Equipment, Structures and Soils," Code of Federal Regulations, Office of the Federal Register, July 14, 2006.

40 CFR 264.171, 2006, "Condition of Containers," Code of Federal Regulations, Office of the Federal Register, July 14, 2006.

40 CFR 264.172, 2006, "Compatibility of Waste with Containers," Code of Federal Regulations, Office of the Federal Register, July 14, 2006.

40 CFR 264.173, 2006, "Management of Containers," Code of Federal Regulations, Office of the Federal Register, July 14, 2006.

40 CFR 264.174, 2006, "Inspections," Code of Federal Regulations, Office of the Federal Register, July 14, 2006.

40 CFR 264.175, 2006, "Containment," Code of Federal Regulations, Office of the Federal Register, July 14, 2006.

40 CFR 264.176, 2006, "Special Requirements for Ignitable or Reactive Waste," Code of Federal Regulations, Office of the Federal Register, July 14, 2006.

40 CFR 264.177, 2006, "Special Requirements for Incompatible Wastes," Code of Federal Regulations, Office of the Federal Register, July 14, 2006.

40 CFR 265.382, 2006, “Open Burning; Waste Explosives," Code of Federal Regulations, Office of the Federal Register, July 14, 2006.

40 CFR 266.202, 2006, "Definition of Solid Waste," Code of Federal Regulations, Office of the Federal Register, July 14, 2006.

40 CFR 266.205, 2006, "Standards Applicable to the Storage of Solid Waste Military Munitions," Code of Federal Regulations, Office of the Federal Register, July 14, 2006.

40 CFR 266.206, 2006, "Standards Applicable to the Treatment and Disposal of Waste Military Munitions," Code of Federal Regulations, Office of the Federal Register, July 14, 2006. 
40 CFR 300, 2006, "National Oil and Hazardous Substances Pollution Contingency Plan," Code of Federal Regulations, Office of the Federal Register, October 27, 2006.

43 CFR 10.6, 2006, "Custody," Code of Federal Regulations, Office of the Federal Register, April 3, 2006.

43 CFR 10.10, 2006, "Repatriation," Code of Federal Regulations, Office of the Federal Register, April 3, 2006.

16 USC $\S 470$ h-2, 2004, "Historic Properties Owned or Controlled by Federal Agencies," United States Code, January 19, 2004.

25 USC § 3002, 2004, “Ownership,” United States Code, January 19, 2004.

25 USC § 3005, 2004, “Repatriation,” United States Codes, January 19, 2004.

42 USC $\S 6901$ et seq., 1976, "Resource Conservation and Recovery Act of 1976," United States Code, October 21, 1976. (The 1980 Amendment is cited as the "Solid Waste Disposal Act Amendments of 1980.")

42 USC $\S 9601$ et seq., 1980, “Comprehensive Environmental Response, Compensation and Liability Act of 1980 (CERCLA/Superfund)," United States Code, December 11, 1980.

DOD, 2004, "Real Property Contaminated with Ammunition, Explosives, or Chemical Agents," DOD 6055.9-STD, Chapter 12, October 5, 2004.

DOE M 440.1-1A, 2006, “DOE Explosives Safety Manual,” U.S. Department of Energy, January 9, 2006.

DOE O 430.1B, 2003, "Real Property Asset Management," U.S. Department of Energy, September 24, 2003.

DOE-ID, 1991, Federal Facility Agreement and Consent Order for the Idaho National Engineering Laboratory, Administrative Docket No. 1088-06-120, U.S. Department of Energy Idaho Operations Office; U.S. Environmental Protection Agency, Region 10; Idaho Department of Health and Welfare, December 4, 1991.

DOE-ID, 1992, Declaration of the Record of Decision for Ordnance Interim Action Operable Unit 10-05, Doc. ID: 5137, Rev. 0, U.S. Department of Energy Idaho Operations Office; U.S. Environmental Protection Agency, Region 10; Idaho Department of Health and Welfare, Division of Environmental Quality, June 1992.

DOE-ID, 1997, Engineering Evaluation Cost Analysis for Nontime-Critical Removal Action for Unexploded Ordnance at the Idaho National Engineering and Environmental Laboratory Operable Unit 10-03, DOE/ID-10577, Rev. 1, U.S. Department of Energy Idaho Operations Office, June 1997.

DOE-ID, 1998, Preliminary Scoping Track 2 Summary Report for OU 10-03 Ordnance, DOE/ID-10566, Rev. 0, U.S. Department of Energy Idaho Operations Office, January 1998. 
DOE-ID, 2001, Comprehensive Remedial Investigation/Feasibility Study for Waste Area Groups 6 and 10 Operable Unit 10-04, DOE/ID-10807, Rev. 0, U.S. Department of Energy Idaho Operations Office, August 2001.

DOE-ID, 2002, Record of Decision Experimental Breeder Reactor-I/Boiling Water Reactor Experiment Area and Miscellaneous Sites, Operable Units 6-05 and 10-04, DOE/ID-10980, Rev. 0, U.S. Department of Energy Idaho Operations Office; U.S. Environmental Protection Agency, Region 10; Idaho Department of Environmental Quality, November 2002.

DOE-ID, 2003, Operable Units 6-05 and 10-04, Experimental Breeder Reactor-I/Boiling Water Reactor Experiment Area and Miscellaneous Sites, Remedial Design/Remedial Action Scope of Work, DOE/ID-11035, Rev. 0, U.S. Department of Energy Idaho Operations Office, February 2003.

DOE-ID, 2004, Operations and Maintenance Plan for Operable Units 6-05 and 10-04, Phase I, DOE/ID-11102, Rev. 1, U.S. Department of Energy Idaho Operations Office, February 2004.

DOE-ID, 2005, Idaho National Laboratory Cultural Resource Management Plan, DOE/ID-10997, Rev. 1, U.S. Department of Energy Idaho Operations Office, September 2005.

DOE-ID, 2006a, Field Sampling Plan for the Operable Units 6-05 and 10-04 Remedial Action, Phase IV, DOE/ID-11280, Rev. 0, U.S. Department of Energy Idaho Operations Office, November 2006.

DOE-ID, 2006b, Quality Assurance Project Plan for Waste Area Groups 1, 2, 3, 4, 5, 6, 7, 10, and Removal Actions, DOE/ID-10587, Rev. 9, U.S. Department of Energy Idaho Operations Office, July 2006.

DOE-ID, 2006c, INL Sitewide Institutional Controls Plan, DOE/ID-11042, Rev. 3, U.S. Department of Energy Idaho Operations Office, July 2006.

EPA, 1988, Guidance for Conducting Remedial Investigations and Feasibility Studies Under CERCLA, Interim Final, EPA/540/G-89/004, U.S. Environmental Protection Agency.

EPA, 2002, Test Methods for Evaluating Solid Waste, Physical/Chemical Methods, SW-846, Rev. 5, U.S. Environmental Protection Agency, Office of Solid Waste, August 2002.

EPA, 2004, Region 9 PRG Table, http://www.epa.gov/region9/waste/sfund/prg/files/04prgtable.pdf, U.S. Environmental Protection Agency, Web page updated October 2004, Web page visited September 13, 2006.

Form 450.AP01, "INEEL Gravel/Borrow Source Request Form," current revision, Idaho National Laboratory, Idaho Cleanup Project.

HAD-238, 2006, "Hazard Assessment Document for the Removal and Detonation of Unexploded Ordnance at the INL Hazard Classification," Rev. 1, Idaho National Laboratory, Idaho Cleanup Project, July 2006.

ICP, 2004, Summary Report for the 2004 Time-Critical Removal Action for Unexploded Ordnance at Operable Unit 10-04, ICP/EXT-04-00437, Rev. 0, Idaho National Engineering and Environmental Laboratory, Idaho Completion Project, July 2004. 
IDAPA 58.01.01.650, 1994, "Rules for Control of Fugitive Dust," Idaho Administrative Procedures Act, Idaho Department of Environmental Quality, May 1, 1994.

IDAPA 58.01.01.651, 1994, “General Rules,” Idaho Administrative Procedures Act, Idaho Department of Environmental Quality, May 1, 1994.

IDAPA 58.01.05.006, 2006, "Standards Applicable to Generators of Hazardous Waste," Idaho Administrative Procedures Act, Idaho Department of Environmental Quality, April 11, 2006.

IDAPA 58.01.05.008, 2006, "Standards for Owners and Operators of Hazardous Waste Treatment, Storage and Disposal Facilities," Idaho Administrative Procedures Act, Idaho Department of Environmental Quality, April 11, 2006.

IDAPA 58.01.11.200, 1997, “Ground Water Quality Standards," Idaho Administrative Procedures Act, Idaho Department of Environmental Quality, March 20, 1997.

INEEL, 1999, Summary Report for the 1997 Non-Time Critical Removal Action for Ordnance at Operable Unit 10-03, INEEL/EXT-97-01354, Rev. 0, Idaho National Engineering and Environmental Laboratory, January 1999.

INEEL, 2000, Waste Area Group 10 RDX/TNT CERCLA Treatability Study Final Report, INEEL/EXT-99-01043, Rev. 0, Idaho National Engineering and Environmental Laboratory, March 2000.

INEEL, 2003a, Comprehensive Facility and Land Use Plan, http://cflup.inel.gov/, Idaho National Engineering and Environmental Laboratory, Web page created 2003, Web page visited March 16, 2005.

INEEL, 2003b, U.S. Department of Energy Idaho Operations Office, Lead Agency Action Memorandum Time-Critical Removal Action for Unexploded Ordnance, Operable Unit 10-04, Idaho National Engineering and Environmental Laboratory, INEEL/EXT-02-01033, Rev. 2, Idaho National Engineering and Environmental Laboratory, February 2003.

INEL, 1996, U.S. Department of Energy, Idaho Operations Office Lead Agency Action Memorandum Time-Critical Removal Action Ordnance Areas Operable Unit 10-03 Idaho National Engineering Laboratory (INEL), INEL-96/0313, Idaho National Engineering Laboratory, September 1996.

MCP-540, 2006, “Assigning Quality Levels,” Rev. 17, Manual 10A-Engineering, Idaho National Laboratory, Idaho Cleanup Project, September 2006.

Parsons, 1997, Final Action Report for the Time Critical Removal Action, Operable Unit 10-03, Parsons Infrastructure and Technology Group, Inc., January 28, 1997.

PDD-1029, 2006, “Pollution Prevention Program,” Rev. 3, Idaho National Laboratory, Idaho Cleanup Project, June 2006.

PLN-114, 2006, “INL Emergency Plan/RCRA Contingency Plan,” Rev. 25, Manual 16A-Emergency Preparedness Base Plan, Idaho National Laboratory, October 2006.

PLN-2087, 2006, "Project Execution Plan for the Miscellaneous Sites Cleanup," Rev. 4, Idaho National Laboratory, Idaho Cleanup Project, October 2006. 
PLN-2128, 2006, "Miscellaneous Sites Cleanup Project Health and Safety Plan," Rev. 2, Idaho National Laboratory, Idaho Cleanup Project, October 2006.

Wyle, 1994, Remedial Action Report for the Interim Action to Cleanup Unexploded Ordnance Locations at the INEL (Operable Unit 10-05), 31-ICP-06, Rev. 3, Wyle Laboratories Scientific Services \& Systems Group, May 20, 1994.

Wyle, 1995a, Removal Action Report for the Ordnance Removal Action, Operable Unit 10-03, 31-ICP-06-1, Rev. 2, Wyle Laboratories Scientific Services \& Systems Group, March 24, 1995.

Wyle, 1995b, Addendum to the Removal Action Report for the Ordnance Removal Action, Operable Unit 10-03, Wyle Laboratories Scientific Services \& Systems Group, October 31, 1995. 


\section{Appendix A}

Air Emissions Analysis for Detonation of Unexploded Ordnance, Waste Area Group 10 


$$
\text { A-2 }
$$




\title{
AIR EMISSIONS ANALYSIS \\ FOR DETONATION OF UNEXPLODED ORDNANCE, WASTE AREA GROUP 10
}

\author{
C. S. Staley, \\ CWI Environmental Services \\ April 10, 2006
}

INTRODUCTION

Idaho Cleanup Project has been remediating soil sites contaminated with various explosive materials as part of the Comprehensive Environmental Response, Compensation, and Liability Act (CERCLA) (42 USC § 9601 et seq.) remedial action for Operable Units 6-05 and 10-04 at the Idaho National Laboratory (INL). These explosive remnants are legacy material from munitions testing performed at the INL. Phase IV of the project will remediate hazards associated with unexploded ordinance (UXO). UXO will be removed from several areas and disposed by high-order detonation at the Mass Detonation Area (MDA), which is located at the INL. Following disposal of UXO, the MDA itself will be remediated. Remediation of the contaminated soil at the MDA will include (a) sampling and analysis of soil (to determine excavation requirements), (b) excavating contaminated soil, (c) backfilling and contouring excavated areas, (d) revegetating affected areas, and (e) monitoring air and soil during the remedial action. Because the degree of contamination of the MDA presently is unknown, the focus of this air emissions analysis is on the detonation and products of detonation of the UXO.

\section{ASSUMPTIONS AND METHODS}

The UXO will be detonated at the MDA. The MDA is located $1.6 \mathrm{~km}$ east of Mile Marker 8 on Lincoln Boulevard, north of Idaho Nuclear Technology and Engineering Center (INTEC) and east of the Naval Reactors Facility (NRF) (see Figure A-1). The entire MDA encompasses approximately 322 ha (796 acres). The specific area chosen for detonation of the UXO is a crater within the MDA, with approximate coordinates E 309536, N 718775 (State Plane, Idaho East Zone 1101, U.S. Survey Feet, Horizontal Datum NAD-27).

Although the exact quantity and mix of UXO are unknown, a bounding estimate for a single detonation for air emissions calculations is $30 \mathrm{lb}(13.6 \mathrm{~kg})$ of material. The UXO contains trinitrotoluene (TNT) and Royal Demolition Explosive (RDX). The worse-case explosive from an emissions standpoint is TNT, so the entire $30 \mathrm{lb}$ is assumed to be TNT. Detonation emissions rates from TNT for carbon monoxide $(\mathrm{CO})$, ammonia $\left(\mathrm{NH}_{3}\right)$, and hydrogen cyanide $(\mathrm{HCN})$ are 796,29 , and $27 \mathrm{lb} /$ ton TNT, respectively, based on the U.S. Environmental Protection Agency's (EPA's), AP-42, Section 13.3, "Explosives Detonation," Table 13.3-1 (EPA 1980).

$\mathrm{PM}_{10}$ emissions $\left(\mathrm{PM}_{10}=\right.$ particulates with a diameter less than $\left.10 \mu\right)$ were estimated based on emission factors from EPA's AP-42, Section 11.9, "Emission Factors for Western Surface Coal Mining" (EPA 1998). From Table 11.9-1, the equation for calculating emissions of $\leq 30 \mu \mathrm{m}$ particle size from blasting is

$$
\operatorname{ParticulateMass}(\mathrm{lb})=0.000014(A)^{1.5}
$$

Where $\mathrm{A}=$ horizontal surface area affected. 


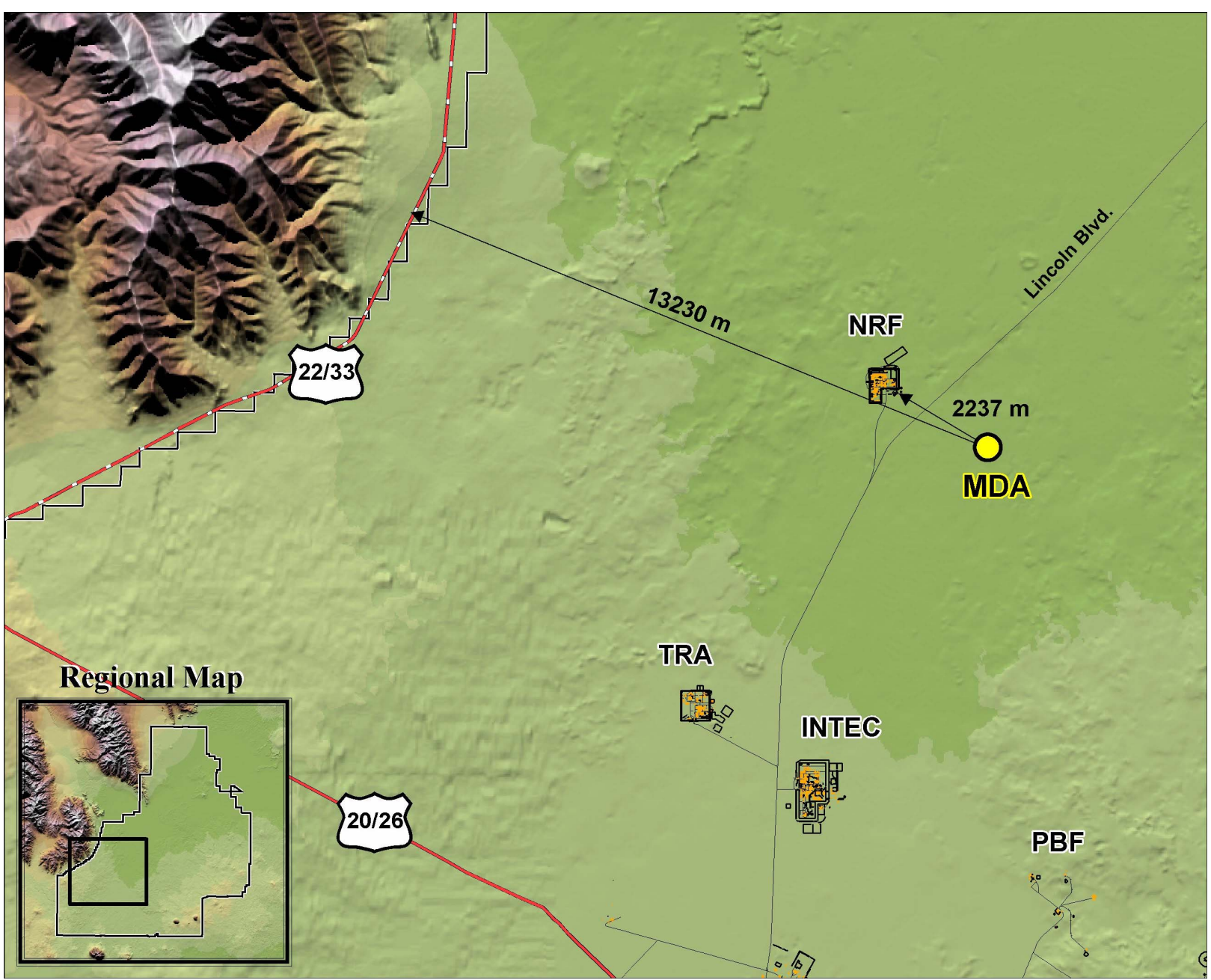

Figure A-1. Location of Mass Detonation Area at INL and distances to nearest receptors.

For this assessment, a generous surface area of 60- $\mathrm{ft}$ diameter ( $30-\mathrm{ft}$ radius) — or about 2,830 $\mathrm{ft}^{2}$ was assumed, giving a particulate mass of $2.1 \mathrm{lb}(953 \mathrm{~g})$ to be emitted. All particulate matter (PM) released is assumed to be $\mathrm{PM}_{10}$, a conservative assumption.

The model chosen for modeling downwind concentrations of contaminants from the detonation was EPA's TSCREEN (Toxics Screening) model. This code was chosen over more complex and refined codes, such as the Open Burn Open Demolition Model, following standard modeling protocol of first modeling with a screening code, then more refined codes as results warrant. The model was downloaded from EPA's Support Center for Regulatory Air Models (SCRAM) website. Essentially, the model is the widely used SCREEN3 code, with provisions for a "puff" release. The input parameters selected include the following:

- $\quad$ Gaseous release (TSCREEN gives identical results for particulate release)

- $\quad$ Discharge from equipment opening (most applicable case; other cases, such as "instantaneous leak from reservoir" required input such as "reservoir pressure," which were not applicable to the MDA)

- $\quad 1 \mathrm{~g}$ material released (unit release is scaled to actual releases) 
- $\quad$ Release height $=0 \mathrm{~m}$

- Initial horizontal and vertical dispersion set to $0 \mathrm{~m}$ (most conservative case)

- Instantaneous release.

As with most screening codes, TSCREEN uses pre-sent, generic, worst-case meterological conditions to model plume dispersion; the plume is assumed to travel directly towards the receptor, no matter the direction. Distance to the receptor is the only important input following release of a contaminant. Two model runs were made, corresponding to the distances to the nearest highway (State Hwy 22/33, 13,230 m WNW) and nearest facility (NRF, 2,237 m NW). TSCREEN code outputs are attached as Appendix A-A.

\section{RESULTS}

Table A-1 presents results of TSCREEN modeling to the nearest INL facility (i.e., NRF), where worker exposure limits apply. Concentrations of $\mathrm{CO}, \mathrm{NH}_{3}$, and $\mathrm{HCN}$ would be below worker exposure limits. PM $_{10}$ may approach the American Conference of Governmental Industrial Hygienists (ACGIH) "Guideline," but a number of conservatisms are built into the calculations, including (1) large surface area affected by blast, (2) all PM is $\mathrm{PM}_{10}$, and (3) plume drifts NW, when the prevailing wind direction is SW to NE, make it unlikely that concentrations in Table A-1 would be realized.

Table A-2 presents results of TSCREEN modeling to the nearest ambient air location, State Hwy 22/33. Concentrations would be below applicable air quality limits. These calculated concentrations are based on conservative release assumptions and conservative modeling; actual concentrations are expected to be lower.

Table A-1. Air emission impacts of UXO detonation at nearest worker facility (NRF).

\begin{tabular}{|c|c|c|c|c|c|c|}
\hline & $\begin{array}{c}\text { Grams } \\
\text { Released }^{\mathrm{a}}\end{array}$ & $\begin{array}{c}\text { Unit Release } \\
\text { Concentration } \\
\left(\mathrm{mg} / \mathrm{m}^{3} / \mathrm{g}\right)^{\mathrm{b}} \\
\text { @ } 2,237 \mathrm{~m} \\
\text { (NRF Fence) }\end{array}$ & $\begin{array}{c}\text { Averaging } \\
\text { Time }\end{array}$ & $\begin{array}{c}\text { Average } \\
\text { Concentration at } \\
2,237 \mathrm{~m} \\
(\mathrm{NRF} \text { Fence }) \\
\left(\mathrm{mg} / \mathrm{m}^{3}\right) \\
\end{array}$ & $\begin{array}{c}\mathrm{TLV}^{\mathrm{c}} \\
\left(\mathrm{mg} / \mathrm{m}^{3}\right) \\
\end{array}$ & $\begin{array}{c}\text { Type of } \\
\text { Limit }\end{array}$ \\
\hline $\mathrm{CO}$ & 5,421 & $1.0 \mathrm{E}-04$ & $8 \mathrm{hr}$ & 0.6 & 28.6 & TWA \\
\hline $\mathrm{NH}_{3}$ & 197 & $1.0 \mathrm{E}-04$ & $8 \mathrm{hr}$ & 0.02 & 17.4 & TWA \\
\hline $\mathrm{HCN}$ & 184 & $3.3 \mathrm{E}-03$ & 15 minutes & 0.6 & 5.2 & STEL \\
\hline $\mathrm{PM}_{10}$ & 953 & $3.3 \mathrm{E}-03$ & 15 minutes & 3.2 & 3.0 & "Guideline"d \\
\hline \multicolumn{7}{|c|}{$\begin{array}{l}\text { a. Based on 30-lb TNT and AP-42 Emission Factors; particulates calculated from AP-42, Table 11.9-1, and 60-ft-diameter } \\
\text { affected surface. } \\
\text { b. The } 8 \text {-hr value is TSCREEN 1-hr value divided by 8; } 15 \text {-min. value is direct TSCREEN output. } \\
\text { c. From ACGIH, } 2006 \text {, "TLVs and BEIs." } \\
\text { d. This is an ACGIH guideline, not a TLV. No averaging time is specified, so } 15 \text { minutes was chosen for conservatism. }\end{array}$} \\
\hline \multicolumn{7}{|c|}{ 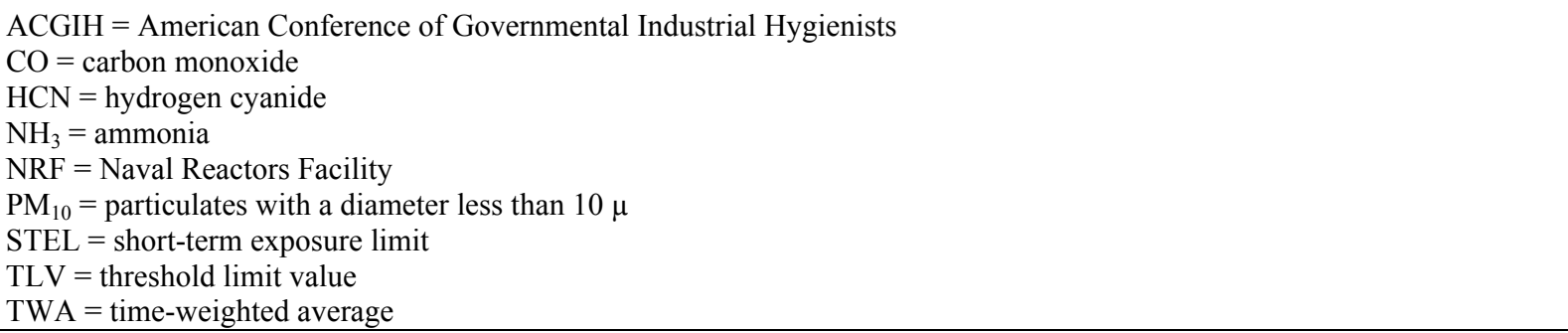 } \\
\hline
\end{tabular}


Table A-2. Air emissions impacts of UXO detonation at nearest ambient air location (State Hwy 22/33).

\begin{tabular}{|c|c|c|c|c|c|c|}
\hline & $\begin{array}{c}\text { Grams } \\
\text { Released }^{\text {a }} \\
\end{array}$ & $\begin{array}{c}\text { Unit Release } \\
\text { Concentration } \\
\left(\mathrm{mg} / \mathrm{m}^{3} / \mathrm{g}\right)^{\mathrm{b}} \\
@ 13,230 \mathrm{~m} \\
\text { (State Hwy 22/33) }\end{array}$ & $\begin{array}{c}\text { Averaging } \\
\text { Time }\end{array}$ & $\begin{array}{c}\text { Average } \\
\text { Concentration at } \\
13,230 \mathrm{~m} \\
(\text { State Hwy 33) } \\
\left(\mathrm{mg} / \mathrm{m}^{3}\right) \\
\end{array}$ & $\begin{array}{c}\text { State of } \\
\text { Idaho Limit } \\
\left(\mathrm{mg} / \mathrm{m}^{3}\right)\end{array}$ & $\begin{array}{c}\text { Type of } \\
\text { Limit }\end{array}$ \\
\hline $\mathrm{CO}$ & 5,421 & $5.8 \mathrm{E}-05$ & $1 \mathrm{hr}$ & 0.3 & 40 & NAAQS \\
\hline $\mathrm{NH}_{3}$ & 197 & & & 0.0005 & 0.9 & $\mathrm{AAC}$ \\
\hline $\mathrm{HCN}$ & 184 & $2.4 \mathrm{E}-06$ & $24 \mathrm{hr}$ & 0.0004 & 0.25 & AAC \\
\hline $\mathrm{PM}_{10}$ & 953 & & & 0.002 & 0.15 & NAAQS \\
\hline \multicolumn{7}{|c|}{$\begin{array}{l}\text { a. Based on } 30-1 \mathrm{lb} \text { TNT and AP-42 Emission Factors; particulates calculated from AP-42, Table } 11 \\
\text { affected surface. } \\
\text { b. The } 24-\mathrm{hr} \text { value is TSCREEN 1-hr value divided by } 24 ; 1 \text {-hr. value is direct TSCREEN output. }\end{array}$} \\
\hline $\begin{array}{l}\text { AAC } \\
\mathrm{CO} \\
\mathrm{HCN} \\
\text { NAAQS } \\
\mathrm{NH}_{3} \\
\mathrm{PM}_{10} \\
\end{array}$ & \multicolumn{6}{|c|}{$\begin{array}{l}=\text { acceptable ambient concentration } \\
=\text { carbon monoxide } \\
=\text { hydrogen cyanide } \\
=\text { National Ambient Air Quality Standards } \\
=\text { ammonia } \\
=\text { particulates with a diameter less than } 10 \mu\end{array}$} \\
\hline
\end{tabular}

\section{REFERENCES}

42 USC $\S 9601$ et seq., 1980, “Comprehensive Environmental Response, Compensation, and Liability Act of 1980 (CERCLA/Superfund)," United States Code, December 11, 1980.

ACGIH, 2006, "TLVs and BEIs,” American Conference of Governmental Industrial Hygienists, 2006.

EPA, 1998, Compilation of Air Pollutant Emission Factors, Volume 1; Stationary Point and Area Sources, Chapter 11: Mineral Products Industry, AP 42, Fifth Edition, U.S. Environmental Protection Agency, http://www.epa.gov/ttn/chief/ap42/index.html, October 1998.

EPA, 1980, Compilation of Air Pollutant Emission Factors, Volume 1; Stationary Point and Area Sources, Chapter 13: Miscellaneous Sources, AP 42, Fifth Edition, http://www.epa.gov/ttn/chief/ap42/index.html, U.S. Environmental Protection Agency, February 1980. 
Appendix A-A

\section{TSCREEN Output Files}


A-8 


\section{TSCREEN OUTPUT FILE}

\section{TNT Detonation - concentrations at Hwy 22/33}

TOTAL AMOUNT OF MATERIAL RELEASED (G): 1.000

RELEASE HEIGHT ABOVE GROUND (M): .0000 INITIAL LATERAL DISPERSION SIGMA (Y) (M): .0000 INITIAL VERTICAL DISPERSION SIGMA (Z) (M): .0000

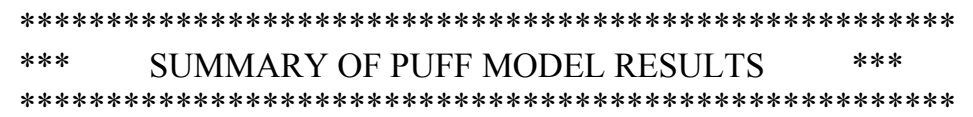

THE MAXIMUM CONCENTRATION AND THE DISTANCE TO MAXIMUM CONCENTRATION FOR DISTANCES BEYOND FENCELINE 13.230 (KM). FOR NEAR SURFACE RELEASE MAXIMUM CONCENTRATION WILL OCCUR AT THE FENCELINE.

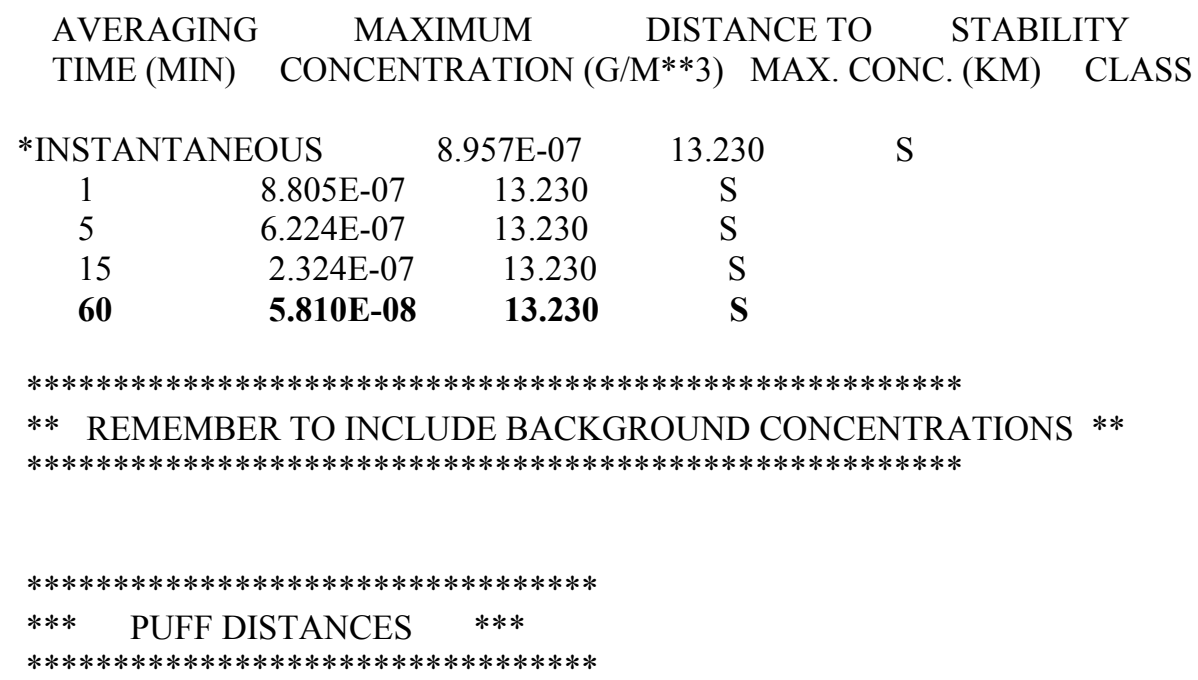

THE MAXIMUM CONCENTRATION AS A FUNCTION OF DOWNWIND DISTANCE AND THE CONDITIONS THAT PRODUCED THE MAXIMUM AT THAT DISTANCE.

MIXING HEIGHT (M) 320.

WIND SPEED (M/SEC) 1.0

AVERAGING DOWNWIND DISTANCE (KM)

TIME (MIN) MAXIMUM CONCENTRATION (G/M**3) AT VARIOUS DOWNWIND DISTANCES.

STABILITY CLASS THAT PRODUCED THE MAX. LISTED BELOW $\begin{array}{llllll}0.01 & 0.03 & 0.05 & 0.07 & 0.1 & 0.5\end{array}$

*INST. 1.005E+01 1.500E+00 5.024E-01 2.344E-01 1.024E-01 2.246E-03

$\begin{array}{llllll}\mathrm{S} & \mathrm{S} & \mathrm{S} & \mathrm{S} & \mathrm{S} & \mathrm{S}\end{array}$

$1 \quad 1.678 \mathrm{E}-01$ 3.229E-02 1.501E-02 9.058E-03 5.305E-03 4.745E-04

$\begin{array}{llllll}\mathrm{S} & \mathrm{S} & \mathrm{S} & \mathrm{S} & \mathrm{S} & \mathrm{S}\end{array}$

$5 \quad 3.355 \mathrm{E}-02$ 6.457E-03 3.001E-03 1.812E-03 1.061E-03 9.490E-05

$\begin{array}{llllll}\mathrm{S} & \mathrm{S} & \mathrm{S} & \mathrm{S} & \mathrm{S} & \mathrm{S}\end{array}$ 
15 1.118E-02 2.152E-03 1.000E-03 6.039E-04 3.537E-04 3.163E-05

$$
\mathrm{S} S \mathrm{~S} \quad \mathrm{~S} S \mathrm{~S} S \mathrm{~S}
$$

$60 \quad$ 2.796E-03 5.381E-04 2.501E-04 1.510E-04 8.842E-05 7.908E-06

$$
\begin{array}{lllllll}
\mathrm{S} & \mathrm{S} & \mathrm{S} & \mathrm{S} & \mathrm{S} & \mathrm{S}
\end{array}
$$

AVERAGING DOWNWIND DISTANCE (KM)

TIME (MIN) MAXIMUM CONCENTRATION (G/M**3) AT VARIOUS DOWNWIND DISTANCES. STABILITY CLASS THAT PRODUCED THE MAX. LISTED BELOW

$\begin{array}{llllll}1.0 & 3.0 & 5.0 & 7.0 & 10.0 & 30.0\end{array}$

*INST. 4.291E-04 3.107E-05 9.166E-06 4.101E-06 1.749E-06 1.266E-07

$$
\begin{array}{llllll}
\mathrm{S} & \mathrm{S} & \mathrm{S} & \mathrm{S} & \mathrm{S} & \mathrm{S}
\end{array}
$$

$1 \quad$ 1.675E-04 2.493E-05 8.344E-06 3.892E-06 1.700E-06 1.261E-07

15 1.118E-05 2.152E-06 1.000E-06 6.039E-07 3.537E-07 6.672E-08

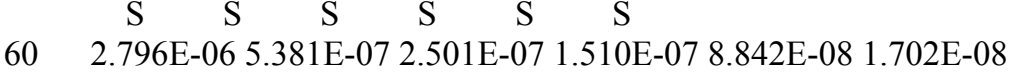

$$
\mathrm{S} \quad \mathrm{S} S \mathrm{~S} S \mathrm{~S} \quad \mathrm{~S}
$$

STABILITY CLASSES

$\mathrm{U}=$ UNSTABLE

$\mathrm{N}=$ NEUTRAL

$\mathrm{S}=\mathrm{STABLE}$

* INDICATES AVERAGING TIME THAT WAS SELECTED FOR PLOTTING 
TSCREEN OUTPUT FILE

TNT Detonation - concentrations at NRF fenceline

TOTAL AMOUNT OF MATERIAL RELEASED (G): 1.000

RELEASE HEIGHT ABOVE GROUND (M): .0000

INITIAL LATERAL DISPERSION SIGMA (Y) (M): .0000

INITIAL VERTICAL DISPERSION SIGMA (Z) (M): .0000

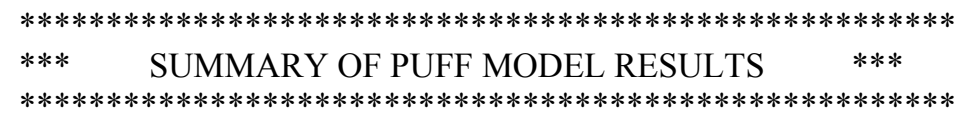

THE MAXIMUM CONCENTRATION AND THE DISTANCE TO MAXIMUM

CONCENTRATION FOR DISTANCES BEYOND FENCELINE $\mathbf{2 . 2 3 7}$ (KM).

FOR NEAR SURFACE RELEASE MAXIMUM CONCENTRATION WILL OCCUR AT

THE FENCELINE.

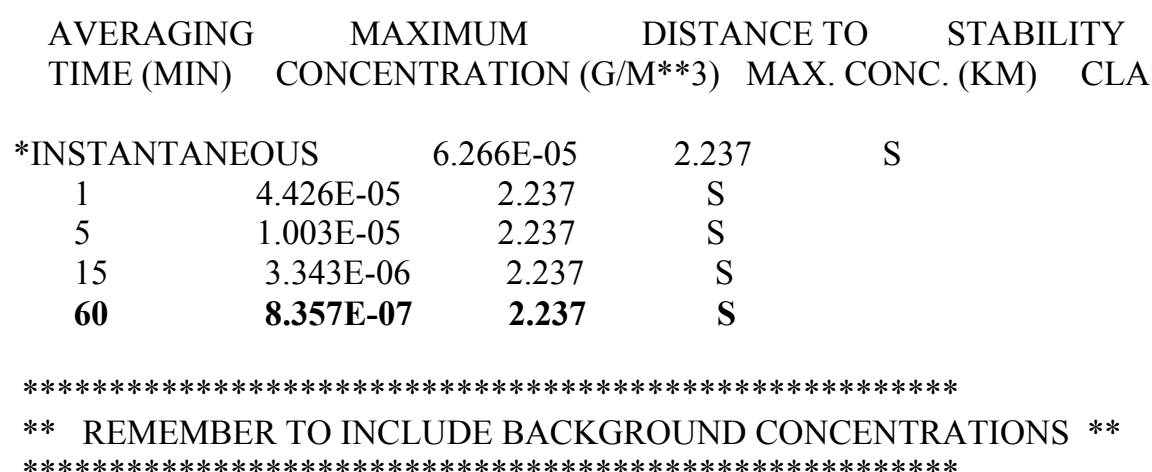

$* * * * * * * * * * * * * * * * * * * * * * * * * * * * * * * * *$

$* * * \quad$ PUFF DISTANCES $* * *$

$* * * * * * * * * * * * * * * * * * * * * * * * * * * * * * * * *$

THE MAXIMUM CONCENTRATION AS A FUNCTION OF DOWNWIND DISTANCE AND THE CONDITIONS THAT PRODUCED THE MAXIMUM AT THAT DISTANCE.

MIXING HEIGHT (M) 320.

WIND SPEED (M/SEC) 1.0

AVERAGING DOWNWIND DISTANCE (KM)

TIME (MIN) MAXIMUM CONCENTRATION (G/M**3) AT VARIOUS DOWNWIND DISTANCES.

STABILITY CLASS THAT PRODUCED THE MAX. LISTED BELOW

$\begin{array}{llllll}0.01 & 0.03 & 0.05 & 0.07 & 0.1 & 0.5\end{array}$

*INST. 1.005E+01 1.500E+00 5.024E-01 2.344E-01 1.024E-01 2.246E-03

$\begin{array}{llllll}\mathrm{S} & \mathrm{S} & \mathrm{S} & \mathrm{S} & \mathrm{S} & \mathrm{S}\end{array}$

$1 \quad 1.678 \mathrm{E}-01$ 3.229E-02 1.501E-02 9.058E-03 5.305E-03 4.745E-04

$\begin{array}{llllll}\mathrm{S} & \mathrm{S} & \mathrm{S} & \mathrm{S} & \mathrm{S} & \mathrm{S}\end{array}$

5 3.355E-02 6.457E-03 3.001E-03 1.812E-03 1.061E-03 9.490E-05

$\begin{array}{llllll}\mathrm{S} & \mathrm{S} & \mathrm{S} & \mathrm{S} & \mathrm{S} & \mathrm{S}\end{array}$

15 1.118E-02 2.152E-03 1.000E-03 6.039E-04 3.537E-04 3.163E-05

$\begin{array}{llllll}\mathrm{S} & \mathrm{S} & \mathrm{S} & \mathrm{S} & \mathrm{S} & \mathrm{S}\end{array}$ 
$60 \quad 2.796 \mathrm{E}-03$ 5.381E-04 2.501E-04 1.510E-04 8.842E-05 7.908E-06

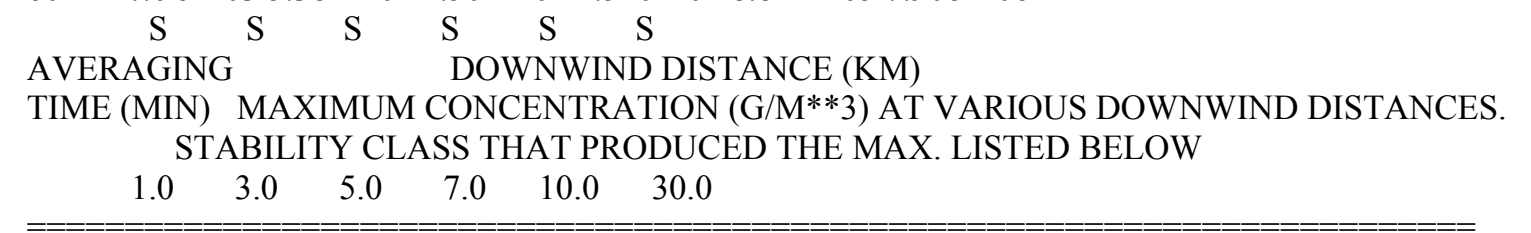

*INST. 4.291E-04 3.107E-05 9.166E-06 4.101E-06 1.749E-06 1.266E-07

$$
\mathrm{S} S \mathrm{~S} \quad \mathrm{~S} \text { S S }
$$

$1 \quad$ 1.675E-04 2.493E-05 8.344E-06 3.892E-06 1.700E-06 1.261E-07

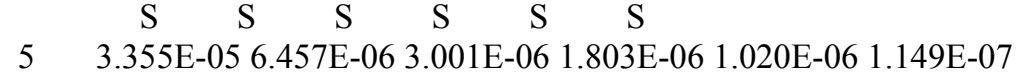

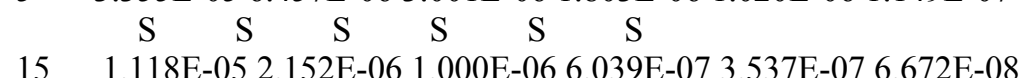

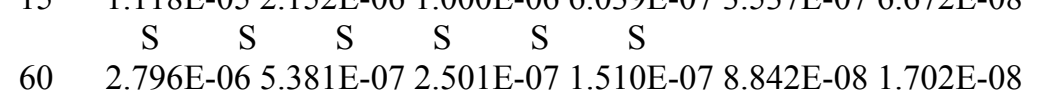

$\begin{array}{ccccccc}60 & 2.796 \mathrm{E}-06 & 5.381 \mathrm{E}-07 & 2.501 \mathrm{E}-07 & 1.510 \mathrm{E}-07 & 8.842 \mathrm{E}-08 & 1.702 \mathrm{E}-08 \\ & \mathrm{~S} & \mathrm{~S} & \mathrm{~S} & \mathrm{~S} & \mathrm{~S} & \mathrm{~S}\end{array}$

STABILITY CLASSES

$\mathrm{U}=$ UNSTABLE

$\mathrm{N}=$ NEUTRAL

$\mathrm{S}=\mathrm{STABLE}$

* INDICATES AVERAGING TIME THAT WAS SELECTED FOR PLOTTING

$* * * * * * * * * * * * * * * * * * * * * * * * * * * * * * * *$

*** END OF PUFF MODEL OUTPUT $* * *$

$* * * * * * * * * * * * * * * * * * * * * * * * * * * * * * * *$ 
Appendix B

Waste Management Plan 
B-2 


\section{Appendix B}

\section{Waste Management Plan \\ B-1. PURPOSE/INTRODUCTION}

The purpose of this Waste Management Plan is to establish requirements for the management and disposal of waste generated during the recovery, excavation, transportation, and disposal activities conducted during the Operable Unit (OU) 10-04 Phase IV remediation of unexploded ordnance (UXO) -contaminated sites at the Idaho National Laboratory (INL). These work activities will be performed under the purview of Waste Area Group (WAG) 10 at the INL. The scope of this plan covers industrial and hazardous waste generated as a result of the OU 10-04 remediation activities conducted at UXO-contaminated sites at the INL. This plan allows for the disposition of waste at approved on-Site treatment and disposal facilities or off-Site treatment and disposal facilities, as deemed appropriate. The plan also provides reference to the applicable waste management requirements that are contained in U.S. Department of Energy Idaho Operations Office (DOE-ID) documentation. The overall scope of the OU 10-04 Phase IV remediation activities is presented in the main body of this report, Remedial Design/Remedial Action Work Plan for Operable Units 6-05 and 10-04, Phase IV.

Activities that could likely generate waste include, but are not limited to, the following:

- $\quad$ Performing manual recovery of UXO

- $\quad$ Performing manual recovery of explosive fragments, as applicable

- Detonating UXO or explosive fragments

- $\quad$ Excavating explosive-contaminated soil

- $\quad$ Performing field screening and sampling

- $\quad$ Performing on-Site stabilization (at the Staging, Storage, Sizing, and Treatment Facility) of soil or microencapsulation of debris, as necessary

- Decontaminating equipment and materials

- $\quad$ Performing packaging, transportation, and disposal activities

- Performing reclamation of the terrain, including backfilling, contouring, and revegetation.

\section{B-2. PROJECT-SPECIFIC WASTE CHARACTERISTICS}

Several distinct waste types could be generated during this project as a result of remediation activities, including the following:

- UXO fragments

- $\quad$ Explosive fragments

- $\quad$ Soil, gravel, and rock

- $\quad$ Personal protective equipment (PPE)

- $\quad$ Plastic sheeting, sampling debris, etc. 
- Hydraulic oil or diesel fuel spills

- $\quad$ Liquid decontamination residue

- $\quad$ Solid decontamination residue

- Noncontaminated debris.

Some of this waste may be clean, but much of it could be contaminated. Subsequent to generation, any or all of the waste may be reclassified. Resource Conservation and Recovery Act (RCRA) -regulated constituents (42 United States Code [USC] $\S 6901$ et seq.) previously encountered in soil samples collected from UXO and explosive-contaminated sites at the INL include explosive by-products (2,4-dinitrotoluene); metals (barium, cadmium, chromium, lead, mercury, selenium, and silver); and organics (chlorobenzene and pentachlorophenol). Based upon available analytical data, only 2,4-dinitrotoluene and lead have exceeded the toxicity characteristic regulatory level for limited quantities of soil. Further characterization of soil for the toxicity characteristic must be performed prior to direct disposal of contaminated soil to determine whether it is characteristic. If the soil is determined to exceed the toxicity characteristic concentration for any analyte, it will require either treatment or stabilization prior to disposal depending on the contaminant.

\section{B-3. WASTE IDENTIFICATION}

Based on a review of work activities and previously collected analytical data, the following potential waste types have been identified:

- Industrial waste: Solid waste generated by industrial processes, manufacturing, and support processes (40 Code of Federal Regulations [CFR] 243, "Guidelines for the Storage and Collection of Residential, Commercial, and Industrial Solid Waste"). At the INL, industrial waste to be disposed of at the INL Landfill Complex does not include hazardous waste, radioactive waste, or land disposal restricted waste regulated under Subtitle C of the RCRA (DOE-ID 2005).

- Hazardous waste: Solid waste designated as hazardous by the U.S. Environmental Protection Agency (EPA) RCRA regulations (40 CFR 261.3, "Definition of Hazardous Waste").

For the Idaho CERCLA Disposal Facility (ICDF) landfill, the Waste Acceptance Criteria guidelines for trinitrotoluene (TNT) and Royal Demolition Explosive (RDX) are $11 \mathrm{mg} / \mathrm{kg}$ and $10 \mathrm{mg} / \mathrm{kg}$, respectively. The ICDF landfill Waste Acceptance Criteria maximum masses for TNT and RDX are $8,400 \mathrm{~kg}$ and $7,900 \mathrm{~kg}$, respectively. Other potential contaminants will require consideration on a case-by-case basis. If either TNT or RDX-contaminated soil to be disposed of exceeds the ICDF landfill Waste Acceptance Criteria (DOE-ID 2006) or if another contaminant (e.g., byproducts of the manufacture or disposal of TNT and RDX) is present that either exceeds the ICDF landfill Waste Acceptance Criteria or for which a criterion is not developed, a proposed revision to the criteria will be submitted to the Agencies for their review and approval to allow for the disposal. For example, the ICDF landfill Waste Acceptance Criteria currently does not include 1,3-dinitrobenzene. If contaminated soil from a UXO site containing 1,3-dinitrobenzene is to be disposed of at the ICDF landfill, the Waste Acceptance Criteria would need to be revised with concurrence from the Agencies. If the contaminated soil cannot be disposed of at the ICDF Complex, an off-Site treatment and disposal facility shall be identified. 


\section{B-4. WASTE DESIGNATION AND MANAGEMENT}

All generated waste will be characterized as required by RCRA regulations (40 CFR 262.11, "Hazardous Waste Determination"). Hazardous waste determinations will be prepared for each waste stream in accordance with the requirements delineated in Management Control Procedure (MCP) -1390, "Waste Generator Services Waste Management."

Waste generated will be designated and characterized using process knowledge, historical analytical data, and/or analytical data generated during the course of remediation activities. The Waste Generator Services organization will generate and maintain completed hazardous waste determinations for all waste streams as part of the project file. Potential waste streams that might be generated during remediation activities include, but are not limited to, the following:

- Industrial solid waste to be disposed of at the INL Landfill Complex

- Hazardous solid waste to be direct disposed of at the ICDF

- Hazardous solid waste (i.e., RCRA-characteristic soil) to be stabilized and disposed of at the ICDF

- $\quad$ Hazardous solid waste (i.e., RCRA-regulated debris) to be macroencapsulated and disposed of at the ICDF

- Explosive fragments to be disposed of by high-order detonation at the Mass Detonation Area

- $\quad$ UXO to be disposed of by high-order detonation at the Mass Detonation Area.

Once the hazardous waste determinations are completed, the appropriate information will be entered into the INL Integrated Waste Tracking System (IWTS). Waste Generator Services will prepare a Waste Determination Disposition Form prior to the generation of any waste with concurrence from the project personnel. All waste must meet the applicable Waste Acceptance Criteria for the intended treatment/disposal facility prior to disposal.

\section{B-4.1 CFA Landfill Waste Disposal}

Historically, the Central Facilities Area (CFA) Landfills I, II, and III were evaluated under the Comprehensive Environmental Response, Compensation, and Liability Act (CERCLA) as OU 4-12. The risk assessment for OU 4-12 indicated that the landfills did not pose an unacceptable risk to human health or the environment; however, due to uncertainty associated with the landfill contents, it was determined that a remedial action was warranted for the site. Given this determination, a remedy was implemented to minimize these landfills as a source of potential groundwater contamination and reduce potential risks associated with exposure to contaminated waste. The major components of the selected remedy included the following:

- $\quad$ Placement of a native soil cover to a minimum depth of $2 \mathrm{ft}$, compacted and graded to minimize erosion and infiltration of surface water

- Implementation of administrative controls on future land use

- Conducting groundwater, surface water, and/or vadose zone monitoring

- $\quad$ Periodically inspecting the cover and repairing as necessary

- Maintaining institutional controls, including signs, postings, and land-use restrictions. 
Consistent with the Record of Decision, Experimental Breeder Reactor-I/Boiling Water Reactor Experiment Area and Miscellaneous Sites, Operable Units 6-05 and 10-04 (DOE-ID 2002), approximately $2 \mathrm{~m}^{3}\left(2.6 \mathrm{yd}^{3}\right)$ of debris comprised of miscellaneous industrial waste generated during the remediation of the UXO-contaminated sites will be disposed of in the active portion of the INL Landfill

Complex. Based on historical analytical results, the debris is below the human health and ecological risk levels established in the Record of Decision (DOE-ID 2002). The landfill is appropriate for this waste stream, because no contaminants are present that pose an unacceptable threat to the underlying Snake River Plain Aquifer.

The INL Landfill Complex is considered a nonmunicipal solid waste landfill and is operated and maintained in accordance with the substantive requirements of 40 CFR 258, "Criteria for Municipal Solid Waste Landfills." Existing and future landfill cells will be closed in accordance with the applicable regulations.

\section{B-4.2 Industrial Waste}

Solid waste and debris that are not contaminated (not a RCRA-characteristic, listed, or mixed waste) and have been radiologically released are considered industrial waste. This waste may be disposed of at the INL Landfill Complex, subject to meeting that facility's Waste Acceptance Criteria. Industrial waste generated during remediation activities will be transported to the INL Landfill Complex, which is located at the CFA for disposal. The waste must meet the Waste Acceptance Criteria, which are described in the Idaho National Engineering and Environmental Laboratory Waste Acceptance Criteria (DOE-ID 2005), prior to disposal at the landfill. The Idaho National Engineering and Environmental Laboratory Waste Acceptance Criteria (DOE-ID 2005) requires some industrial waste to be segregated and managed as conditional industrial waste.

\section{B-4.3 Hazardous Waste}

Contaminated (hazardous) solid waste (nonaqueous) that meets the ICDF Waste Acceptance Criteria will be treated and disposed of at the ICDF. Contaminated aqueous waste that meets the ICDF Waste Acceptance Criteria will be sent to the ICDF evaporation pond. Aqueous and nonaqueous waste not meeting the ICDF's disposal requirements will be containerized, treated, and/or stored (as necessary) until the appropriate treatment/disposal criteria are met. If management and disposal at INL facilities is not possible, then waste may be sent to an approved off-Site facility for treatment and disposal, subject to meeting the appropriate Waste Acceptance Criteria and off-Site criteria.

\section{B-4.4 Unexploded Ordnance and Explosive Fragments}

Unexploded ordnance and explosive fragments (including TNT and RDX) will be recovered and transported to the Mass Detonation Area for disposal by high-order detonation. Any UXO or fragments that are determined to pose an unacceptable hazard to personnel will be safely handled and transported for detonation or will be disposed of by in-place detonation. A safety assessment will be performed for the identified explosives and a decision to remove, detonate in place, or isolate the identified UXO or explosive will be based on the determined hazard level. 


\section{B-4.5 Contaminated Soils Planned for Treatment, Storage, or Disposal}

Soils that are excavated that require treatment, storage, or disposal will be expeditiously placed in trucks or other transportation containers for transport. When transport is not expeditiously available after excavation (within 5 working days), contaminated soils will be placed in staging piles or appropriate containers (e.g., bags, covered roll-on/roll-offs, metal waste containers, or wooden boxes) to be managed until transport is available. These staging piles or containers will be inspected no less frequently than weekly to ensure the piles or containers are managed in compliance with the standards and requirements contained within this section of the Waste Management Plan pertaining to soil staging.

Staging piles will be managed in accordance with applicable or relevant and appropriate requirements of 40 CFR 264.554. The requirements below provide the Agencies the opportunity to review, comment, and concur with the management of soils under this approach. The Agencies' concurrence with this Waste Management Plan is the CERCLA equivalent of the director's designation of the standards and design criteria that would be required to operate staging piles if this project was regulated under RCRA requirements.

The management of contaminated soils in staging piles requires compliance with the following requirements:

- Contaminated soils shall be stockpiled in staging piles or containers located near or adjacent to the area of excavation.

- Only solid, nonflowing remediation waste that would meet the definition of remediation waste in 40 CFR 260.10 shall be included in the staging piles or containers.

- Treatment of waste in these staging piles or containers is not allowed.

- $\quad$ Staging piles or containers will be used expressly for the purpose of facilitating an effective remedial action.

- $\quad$ Staging piles shall be covered or have stabilization agents applied whenever active remedial activities are not underway (e.g., when active movement of soils either into or out of the pile is not proceeding during normal operational periods) in order to reduce wind-blown or precipitation-enhanced releases of contamination. In case the soils are staged in bags, these shall be closed to isolate the soils from the outside area. However, these bags need not be covered. Run-on/run-off controls will be maintained to preclude pooling of water and possible impact on the surrounding area from the contaminated stockpile.

- $\quad$ Access to the staging piles will be restricted by the use of signs and fences, as appropriate.

- Ignitable and/or reactive soil cannot be stored in staging piles or bags unless the waste has been treated and is no longer ignitable or reactive.

- The staging piles or containers must be established and maintained to ensure separation of incompatible soil and other waste. 
- Upon completion of remediation activities the staging piles will be removed. If the staging piles were placed on the ground, an additional 6 in. of soil will be removed to constitute removal of the staging piles and any soils that were contaminated as a result. These wastes will be disposed of at an approved disposal facility in order to complete remediation activities. The area that was beneath the staging piles is subject to the same confirmation sampling as specified in the Field Sampling Plan for the Operable Units 6-05 and 10-04 Remedial Action, Phase III (DOE-NE-ID 2006), Section 4.2.4, to ensure that the contaminated soils have been effectively removed.

- Removal of the staging piles will constitute closure. If the staging pile wastes were placed on the ground, removal of the staging piles includes the removal of the additional 6 in. of soil and confirmation sampling to verify that the remaining soil meets the remediation goals. Closure of the staging piles will be documented in the prefinal inspection and the remedial action report.

- $\quad$ Contaminated equipment associated with the staging piles will be removed, disposed of, or decontaminated for reuse.

- $\quad$ Staging piles are to be removed by the end of the field season immediately following the field season in which the staging piles were created unless specific approval for an extension is obtained from the Agencies.

\section{B-4.6 Waste Storage}

While waste is being actively generated by the UXO remedial operations, the waste will be temporarily managed within the designated work area in containers appropriate for the type of waste being generated (e.g., hazardous liquids require secondary containment). Unless being actively filled, the containers shall remain closed at all times. The volume of waste retained within the work zone shall be kept to a minimum. All waste located at the task site shall be removed for disposal prior to demobilization. After containers have been filled or work at the site is completed, they shall be removed from the task site within 15 days of generation or a CERCLA storage area established. No waste shall be stored at the task site over the winter, should the remediation timeframe extend beyond the annual shutdown of the ICDF landfill, which is tentatively scheduled for November 15th each year.

Whenever possible, waste containers will be removed from the active work area directly to the ICDF or the INL Landfill Complex, as appropriate. If temporary storage is required, a staging area will be established within the area of concern. Waste stored there will be labeled and roped off in compliance with applicable company and regulatory requirements. If the waste is stored at the treatment, storage, and disposal facility, the CERCLA-regulated waste (42 USC $\S 9601$ et seq.) will be managed in accordance with that facility's waste management plan.

If direct transfer of small waste containers (i.e., drums or boxes) to the treatment, storage, and disposal facility is not feasible, containers may be stored temporarily in an established CERCLA storage area located in the CFA-637 building. This could be necessary pending container profile approvals and facility acceptance. If temporary storage is required because of space limitations or safety concerns, the CERCLA storage area may be expanded or a new CERCLA storage area may be established as directed by Waste Generator Services to accommodate the waste. 
The CERCLA storage area is located at CFA and managed in accordance with the substantive requirements of RCRA, as applicable, for temporary storage of waste (40 CFR 264, Subpart I, "Use and Management of Containers"). For example, if CERCLA waste with RCRA waste codes is stored in a CERCLA storage area, then the following items are located, tested, and maintained, unless hazards associated with the waste streams would not require the item:

1. Current copy of the registration posted at the CERCLA storage area

2. Communications, spill control, and safety equipment, as identified in the "Miscellaneous Sites Cleanup Project Health and Safety Plan" (PLN-2128)

3. "NO SMOKING" signs at or near a CERCLA storage area that stores ignitable or reactive waste.

Additional requirements include appropriate management of containers at the CERCLA storage area that includes the following:

1. Maintain the containers in good condition

2. Do not store waste that is incompatible with containers (or container liners) or place the waste in a container that previously held an incompatible waste or material

3. Keep all containers closed except when adding, removing, sampling, or measuring waste

4. Do not mix incompatible waste

5. Maintain sufficient aisle space (minimum of $71 \mathrm{~cm} \mathrm{[28} \mathrm{in.])} \mathrm{to} \mathrm{allow} \mathrm{the} \mathrm{unobstructed}$ movement of emergency equipment and personnel

6. Do not open, handle, or store any container in a manner that will cause it to leak

7. Perform and document weekly CERCLA storage area inspections by qualified personnel.

Personnel trained in the management of a CERCLA waste storage area will inspect the temporary storage area weekly. The purpose of the inspections is to evaluate container integrity, verify correct container labeling, and correct any noted deficiency or issue. Inspections are documented on the CERCLA storage area checklist that is maintained within each CERCLA storage area. "Temporary Storage of CERCLA-Generated Waste at the INL Site" (MCP-3475) and "Temporary Waste Management Areas" (MCP-3470) will be used as guidance on storage and inspection of each CERCLA storage area. The CERCLA storage area will be signed and access controlled to ensure that no unauthorized access occurs by untrained personnel.

\section{B-5. WASTE PACKAGING, LABELING, AND TRANSPORTATION}

Containers used to store CERCLA-regulated waste must be in good condition, compatible with the waste being stored, and properly labeled. The Idaho National Engineering and Environmental Laboratory Waste Acceptance Criteria (DOE-ID 2005) details the criteria for waste packaging. Containers for the collection of this waste will be clearly labeled to identify the waste type and will be maintained inside the work area until removal for subsequent waste management activities. The Idaho National Engineering and Environmental Laboratory Waste Acceptance Criteria (DOE-ID 2005) also provides guidance to ensure that the containers selected for storage and the method of packaging are compatible with final disposition plans and applicable U.S. Department of Transportation requirements. Following this guidance will alleviate the need for repackaging the waste before shipment to a treatment or disposal facility. 
The types of containers that may be used for storage and transport of waste streams generated during remedial activities include the following:

- $\quad$ Plastic bags

- 19-L (5-gal) open-head drums and/or 208-L (55-gal) open-head drums or other appropriately sized and approved containers

- 208-L (55-gal) closed-head drums or other approved containers for liquids

- $\quad 1.2 \times 1.2 \times 2.4-\mathrm{m}(4 \times 4 \times 8$-ft) metal waste boxes (or equivalent) or other appropriately sized and approved waste boxes

- $\quad$ Lined roll-off containers

- $\quad$ End-load dump trucks.

Roll-off containers with emplaced liners conforming to the specification requirements for 100-lot rolls, as delineated in the American Society for Testing and Materials (ASTM) D 2103-05 will be used for soil and other solid waste intended for direct disposal in the ICDF landfill. End-load dump trucks may be used, provided they meet the same requirements as those stipulated for the roll-off containers. End-load dump trucks also may be used for waste requiring storage in the ICDF bulk storage area pending treatment required to meet the land disposal restrictions before disposal in the ICDF landfill. Bags, drums, and waste boxes may be used for other solid waste types pending direct disposal or treatment, as required (e.g., construction debris, PPE, or sampling waste). All waste will be containerized in compliance with the facility's Waste Acceptance Criteria, based on specific storage, treatment, and disposal requirements at the receiving facility. The packaging is intended to protect against contaminant migration and environmental degradation. Low-volume contaminated waste associated with activities may be bagged, taped, and labeled. To reduce the number of separate bags, similar waste may be combined and accounted for in one bag and/or container in consultation with Waste Generator Services personnel. During site activities, the workers will transport this bagged material in a protective manner (i.e., containment of the material is maintained). The waste may be either directly transported to the disposal facility or accumulated in a container (or containers) at the CERCLA storage area already established at CFA (or a CERCLA storage area established at the task site) and will be managed pending approval and transport to its final disposition path.

Containers will be marked and labeled appropriately to match the designation established for each waste stream. Uncontaminated waste will be placed in containers labeled appropriately. Containers will be marked with labels identifying them as "CERCLA Waste" if contaminated.

Standard CERCLA waste labels shall include appropriate information on the waste packaging, as follows:

- $\quad$ The accumulation start date

- $\quad$ Name of generating facility (e.g., OU 10-04)

- Waste description

- $\quad$ Phone number of generator contact

- $\quad$ Listed or characteristic code(s), as applicable. 
Other labels and markings may include, as applicable

- Waste package gross weight

- U.S. Department of Transportation marking/labels

- Waste stream or material identification number as assigned by Waste Generator Services

- $\quad$ Other labels and markings as required by 49 CFR 172, Subparts D and E.

A unique bar code number from the INL IWTS also will be placed on the container to facilitate management. The boxes and containers shall, at a minimum, be labeled on one side with the "CERCLA Waste" label and the bar code sticker (visible side labeled) prior to transportation.

Any of the above information that is not known when the waste is labeled may be added when the information becomes available. Waste Generator Services will provide the unique bar codes. A new bar code will be affixed to each container when waste is first placed in the container. In addition, waste labels must be visible, legibly printed or stenciled, and placed so that a full set of labels and markings are readily visible.

Packaging and labeling for transportation shall meet U.S. Department of Transportation requirements, as appropriate, to be evaluated by the Packaging and Transportation organization. Packaging exceptions to these requirements, which are documented and provide an equivalent degree of safety during transportation, may be used for on-Site waste shipments. Containers will be labeled and marked appropriately to match the designation established for each waste stream.

\section{B-6. WASTE MINIMIZATION AND SEGREGATION}

Waste minimization techniques will be incorporated primarily through design, planning, and efficient operations. Specific waste minimization practices to be implemented during the project will include, but not be limited to, the following:

- $\quad$ Sampling to delineate excavation zones

- Excluding materials that could become hazardous waste in the decontamination process (if any)

- Controlling transfer of materials and equipment between clean and contaminated zones

- Designing containment such that spread of contamination is minimized

- Deploying appropriate decontamination methods.

Reuse and recycling opportunities also will be evaluated for waste, such as batteries, scrap metal, and equipment or materials that are no longer needed. Uncontaminated equipment that is determined to be excess will be evaluated for reuse by other INL projects or government surplus sale. 


\section{B-7. REFERENCES}

40 CFR 243, 2002, "Guidelines for the Storage and Collection of Residential, Commercial, and Institutional Solid Waste," Code of Federal Regulations, Office of the Federal Register, February 2002.

40 CFR 258, 2006, "Criteria for Municipal Solid Waste Landfills," Code of Federal Regulations, Office of the Federal Register, January 2006.

40 CFR 260.10, 2006, "Definitions," Code of Federal Regulations, Office of the Federal Register, July 2006.

40 CFR 261.3, 2006, "Definition of Hazardous Waste," Code of Federal Regulations, Office of the Federal Register, October 2006.

40 CFR 262.11, 2006, "Hazardous Waste Determination," Code of Federal Regulations, Office of the Federal Register, August 2006.

40 CFR 264, Subpart I, 2006, "Use and Management of Containers," Code of Federal Regulations, Office of the Federal Register, July 2006.

40 CFR 264.554, 2006, "Staging Piles," Code of Federal Regulations, Office of the Federal Register, July 2006.

49 CFR 172, Subpart D, 2006, "Marking," Code of Federal Regulations, Office of the Federal Register, October 2006.

49 CFR 172, Subpart E, 2006, "Labeling," Code of Federal Regulations, Office of the Federal Register, October 2006.

42 USC § 6901 et seq., 1976, "Resource Conservation and Recovery Act (Solid Waste Disposal Act)," United States Code, October 21, 1976.

42 USC § 9601 et seq., 1980, "Comprehensive Environmental Response, Compensation, and Liability Act of 1980 (CERCLA/Superfund)," United States Code, December 11, 1980.

ASTM D 2103-05, 2005, "Standard Specification for Polyethylene Film and Sheeting," American Society for Testing and Materials, December 2005.

DOE-ID, 2002, Record of Decision, Experimental Breeder Reactor-I/Boiling Water Reactor Experiment Area and Miscellaneous Sites, Operable Units 6-05 and 10-04, DOE/ID-10980, Rev. 0, U.S. Department of Energy Idaho Operations Office; U.S. Environmental Protection Agency, Region 10; Idaho Department of Environmental Quality, November 2002.

DOE-ID, 2005, Idaho National Engineering and Environmental Laboratory Waste Acceptance Criteria, DOE/ID-10381, Rev. 21, U.S. Department of Energy Idaho Operations Office, January 2005.

DOE-ID, 2006, ICDF Complex Waste Acceptance Criteria, DOE/ID-10881, Rev. 3, U.S. Department of Energy Idaho Operations Office, October 2006. 
DOE-NE-ID-2006, Field Sampling Plan for the Operable Units 6-05 and 10-04 Remedial Action, Phase III, DOE/NE-ID-11212, Rev. 1, U.S. Department of Energy Idaho Operations Office, August 2006.

MCP-1390, 2006, "Waste Generator Services Waste Management," Rev. 1, Manual 17-Waste Management, Idaho Completion Project, June 2006.

MCP-3470, 2006, “Temporary Waste Management Areas,” Rev. 5, Manual 17-Waste Management, Idaho Completion Project, June 2006.

MCP-3475, 2006, “Temporary Storage of CERCLA-Generated Waste at the INL Site," Rev. 4, Manual 8-Environmental Protection and Compliance, Idaho Completion Project, June 2006.

PLN-2128, 2006, "Miscellaneous Sites Cleanup Project Health and Safety Plan," Rev. 2, Idaho Completion Project, October 2006. 
B-14 


\section{Appendix C}

\section{Operations and Maintenance Plan for Operable Units 6-05 and 10-04, Phase IV}




$$
\text { C-2 }
$$




\section{Appendix C}

\section{Operations and Maintenance Plan for Operable Units 6-05 and 10-04, Phase IV}

\section{C-1. INTRODUCTION}

Remediation for Operable Units (OUs) 6-05 and 10-04, hereinafter referred to as OU 10-04, at the Idaho National Laboratory (INL) is divided into four phases:

- $\quad$ Phase I consists of developing and implementing institutional controls at OU 10-04 sites and developing and implementing an INL Sitewide institutional controls plan and long-term ecological monitoring plan. The requirements for Phase I have been completed.

- $\quad$ Phase II will remediate sites contaminated with trinitrotoluene (TNT) and Royal Demolition Explosive (RDX).

- $\quad$ Phase III will remediate lead contamination at the Security Training Facility (STF) -02 gun range.

- $\quad$ Phase IV will address hazards from unexploded ordnance (UXO).

Separate remedial design/remedial action work plans and operations and maintenance (O\&M) plans will be submitted for each remediation phase. The scope and schedule for implementing these remediation phases are presented in the Operable Units 6-05 and 10-04, Experimental Breeder Reactor-I/ Boiling Water Reactor Experiment Area and Miscellaneous Sites, Remedial Design/Remedial Action Scope of Work (DOE-ID 2003).

The site-specific O\&M plan describes the long-term activities and procedures that will be performed to satisfy requirements for the Record of Decision Experimental Breeder Reactor-I/ Boiling Water Reactor Experiment Area and Miscellaneous Sites, Operable Units 6-05 and 10-04 (DOE-ID 2002) and the Operable Units 6-05 and 10-04, Experimental Breeder Reactor-I/Boiling Water Reactor Experiment Area and Miscellaneous Sites, Remedial Design/Remedial Action Scope of Work (DOE-ID 2003). These activities and procedures will comprise the Phase IV remediation effort for the UXO-contaminated sites, including the Naval Ordnance Disposal Area (NODA), the Mass Detonation Area (MDA), the Experimental Field Station, the Rail Car Explosion Area, and the Land Mine Fuze Burn Area.

This plan outlines the O\&M activities that will be conducted and documented in the O\&M report at the completion of the remedial action activities at the OU 10-04 sites. After remediation actions at the OU 10-04 sites are complete, this O\&M plan may be modified based on the results of the final confirmation sampling. The institutional control requirements are based on provisions outlined in the INL Sitewide Institutional Controls Plan (DOE-ID 2006).

As remediation in Phases II through IV is completed for the OU 10-04 sites, the O\&M requirements will be modified based on the residual levels of contamination. For the Phase IV activities, it is usually not possible to confirm that all (100\%) of the UXO and associated explosive materials have been identified and therefore removed from a site at the completion of remediation. For this reason, it is anticipated that institutional controls will be required after remediation of the ordnance sites, since undetected ordnance and TNT/RDX fragments could remain. 
The basic elements of this O\&M plan are organized as follows:

- Section C-2-This section provides background information on the nature of contamination at the five sites and a description of the current controls

- $\quad$ Section C-3-This section describes the requirements for institutional controls, environmental monitoring, site-specific operations and maintenance, and 5-year reviews

- $\quad$ Section C-4-This section describes operations and maintenance implementation, including organization, responsibilities, and requirements for conducting monitoring, maintenance, and inspections

- Section C-5-This section summarizes the reporting requirements for institutional controls, environmental monitoring, site-specific operations and maintenance, and 5-year reviews

- Section C-6-This section lists the references cited in this plan.

In accordance with the Federal Facility Agreement and Consent Order for the Idaho National Engineering Laboratory (DOE-ID 1991), the U.S. Department of Energy Idaho Operations Office (DOE-ID) will submit an O\&M report to the U.S. Environmental Protection Agency and the Idaho Department of Environmental Quality (hereinafter referred to as the Agencies) once the O\&M activities have been completed. In accordance with the Remedial Design/Remedial Action Work Plan for Operable Units 6-05 and 10-04, Phase I (DOE-ID 2004a), a draft O\&M report will be submitted to the Agencies by May 31, 2008.

\section{C-2. BACKGROUND}

Located $51 \mathrm{~km}(32 \mathrm{mi})$ west of Idaho Falls, Idaho, the INL is a government-owned, contractor-operated facility managed by DOE-ID. Occupying $2,305 \mathrm{~km}^{2}\left(890 \mathrm{mi}^{2}\right)$ of the northeastern portion of the eastern Snake River Plain, the INL Site encompasses portions of five Idaho counties: (1) Butte, (2) Jefferson, (3) Bonneville, (4) Clark, and (5) Bingham. Waste Area Group (WAG) 10 is comprised of miscellaneous surface sites and liquid disposal areas throughout the INL that are not included within other WAGs (WAGs 1-9). Unexploded ordnance has been found within the Naval Proving Ground (NPG) at the five sites shown in Figure C-1 and is discussed in the following sections. The remediation activities associated with Phase IV will be concentrated in these areas. If ordnance that poses an imminent risk to human health or the environment is encountered elsewhere on the INL, it will be removed and disposed of in accordance with the requirements outlined in the Operations and Maintenance Plan for Operable Units 6-05 and 10-04, Phase I (DOE-ID 2004b).

\section{C-2.1 Naval Ordnance Disposal Area}

The NODA is located approximately $1.6 \mathrm{~km}$ (1 mi) northeast of U.S. Highway 20/26 between Mile Markers 266 and 267 and about $3.2 \mathrm{~km}(2 \mathrm{mi})$ halfway from the Reactor Technology Complex (RTC) (formerly the Test Reactor Area), the Idaho Nuclear Technology and Engineering Center (INTEC), and the Central Facilities Area (CFA) at the INL, as shown in Figure C-1. The NODA was reportedly used by the U.S. Navy as an ordnance and nonradioactive hazardous material disposal area during the 1940s. Following the establishment of the National Reactor Testing Station (now the INL), the NODA came under control of the U.S. Atomic Energy Commission (now DOE). From about 1967 to 1985 , approximately $3,175 \mathrm{~kg}(7,000 \mathrm{lb})$ of reactive materials were treated (burned) at the NODA. Between 1967 and 1985, the NODA also was used as a storage area for hazardous waste generated at the 


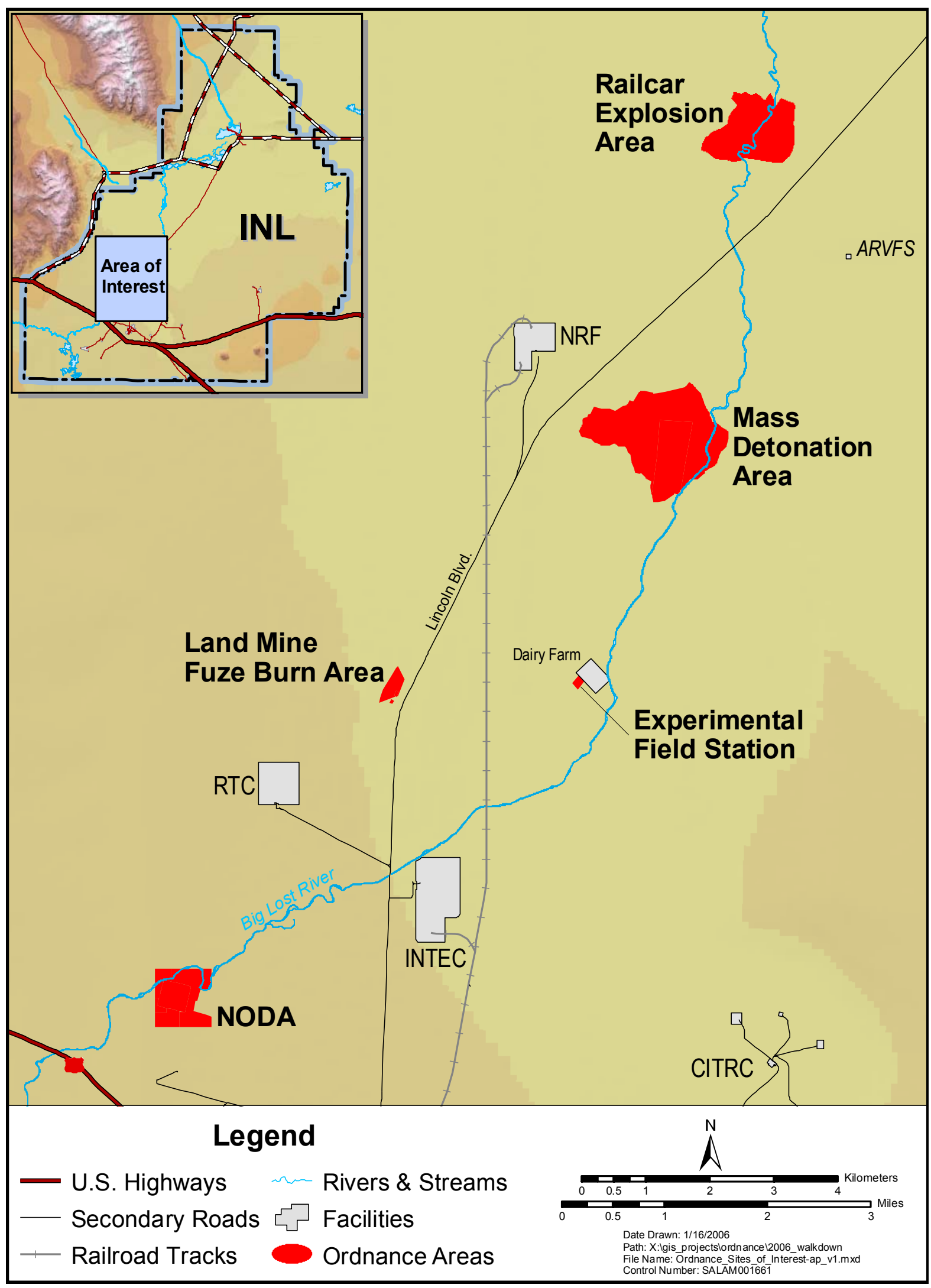

Figure C-1. Primary ordnance sites. 
INL. Solvents, corrosives, ignitable materials, heavy-metal-contaminated solutions, formaldehyde, polychlorinated biphenyl materials, waste laboratory chemicals, and reactive materials were stored at this site until 1982. By October 1985, all these materials had been removed for off-Site disposal as hazardous waste or treated on-Site by open burning, as allowed by Resource Conservation and Recovery Act (RCRA) regulations (DOE-ID 1998).

In 1985, the NODA was added to the RCRA, Part A, permit application as a thermal treatment unit. The last treatment of hazardous waste occurred in 1988 (except for one emergency action/detonation in 1990). In June 1990, a Memorandum of Understanding was developed between the Environmental Programs and Waste Reduction Operations Complex, under which the Environmental Programs agreed to fund and manage all activities necessary to formally close the NODA, including soil sampling and analysis, removal of contaminated soil, emergency removal of ordnance, maintenance of access signs and barricades, and preparation and submittal of all required documentation. In 1998, the Idaho Division of Environmental Quality under the Department of Health and Welfare terminated the Interim Status of the NODA with the agreement that the Comprehensive Environmental Response, Compensation, and Liability Act (CERCLA) Program (42 USC § 9601 et seq.) would perform the final evaluation of the site in accordance with the Federal Facility Agreement and Consent Order for the Idaho National Engineering Laboratory (DOE-ID 1991).

The 1994 removal action defined the cleanup area as 16 ha (40 acres) centered approximately $762 \mathrm{~m}(2,500 \mathrm{ft})$ north of the current INL security force gun range on Portland Avenue. The large number of items removed during two previous actions supports the potential for fuzes, projectiles, and grenades to continue to be present. More detailed information about the NODA site can be found in the Comprehensive Remedial Investigation/Feasibility Study for Waste Area Groups 6 and 10 Operable Unit 10-04 (DOE-ID 2001).

\section{C-2.2 Mass Detonation Area}

The MDA is located $1.6 \mathrm{~km}(1 \mathrm{mi})$ east of Mile Marker 8 on Lincoln Boulevard, north of the INTEC and approximately $3.2 \mathrm{~km}(2 \mathrm{mi})$ east of the Naval Reactors Facility (NRF) as shown in Figure C-1. The site encompasses 322 ha (796 acres) and has been used for a number of small- to large-scale sympathetic and mass detonation tests, with test shots ranging up to $226,800 \mathrm{~kg}(500,000 \mathrm{lb})$ of explosives. A sympathetic detonation test is a test performed to find out if a charge explodes when another charge is detonated next to it. The MDA site includes numerous blast craters varying in dimensions from a few feet to several tens of feet. Historically, large quantities of UXO, pieces of explosives, and structural debris scattered during past testing have been noted at the MDA. In addition, more recent disposal activities associated with previous removal actions, as well as explosive test activities, may have contributed to explosives contamination at the site. More detailed information pertaining to the MDA can be found in the OU 10-04 Comprehensive Remedial Investigation/Feasibility Study (RI/FS) (DOE-ID 2001).

\section{C-2.3 Experimental Field Station}

The Experimental Field Station is located within the NPG gunnery range approximately $9.7 \mathrm{~km}$ (6 mi) downrange and northeast of the CFA-633 NPG firing site and approximately $0.4 \mathrm{~km}(0.25 \mathrm{mi})$ west of the Big Lost River Channel as shown in Figure C-1. The site is an estimated 2 ha (5 acres), although the actual contamination is restricted to approximately $510 \mathrm{~m}^{2}\left(610 \mathrm{yd}^{2}\right)$. This site includes multiple craters within which a variety of explosive tests were conducted. The site is known to contain UXO, pieces of explosives, structural debris, and soil contamination. More detailed information pertaining to the Experimental Field Station is available in the OU 10-04 Comprehensive RI/FS (DOE-ID 2001). 


\section{C-2.4 Rail Car Explosion Area}

The Rail Car Explosion Area is located approximately $3.2 \mathrm{~km}$ (2 mi) due west of Mile Marker 13

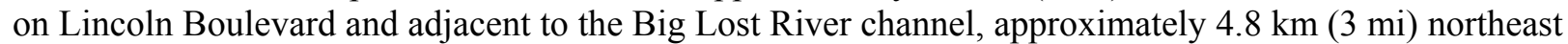
of NRF, as shown in Figure C-1. It encompasses 195 ha (483 acres) and contains the debris scattered from a sympathetic detonation test involving five railroad cars, each loaded with $13,608 \mathrm{~kg}(30,000 \mathrm{lb})$ of explosive ordnance for a total of $68,040 \mathrm{~kg}(150,000 \mathrm{lb})$. The crater is located near the west bank of the Big Lost River, and pieces of ordnance and explosives (mostly RDX) have historically been located along both sides of the Big Lost River as documented in the Preliminary Scoping Track 2 Summary Report for Operable Unit 10-03 Ordnance (DOE-ID 1998). The OU 10-04 Comprehensive RI/FS (DOE-ID 2001) provides additional information pertaining to the Rail Car Explosion Area.

\section{C-2.5 Land Mine Fuze Burn Area}

The Land Mine Fuze Burn Area is $0.8 \mathrm{~km}(0.5 \mathrm{mi})$ west of Lincoln Boulevard and approximately $0.8 \mathrm{~km}(0.5 \mathrm{mi})$ north of the Fire Station II training area (Mile Marker 5), as shown in Figure C-1. The site consists of approximately five separate ordnance disposal locations in an 8.1-ha (20-acre) area between a meander of a former channel of the Big Lost River and an old abandoned irrigation canal that was hand-dug in the early 1900s (DOE-ID 2001). Based upon visual observation of the site, the contaminated area of the site is restricted to a few square meters in a single location. As described in the Preliminary Scoping Track 2 Summary Report for Operable Unit 10-03 Ordnance (DOE-ID 1998), the site was used by NPG personnel for disposal of land mine pressure plates and aerial bomb packaging materials and as an area to dispose of land mine fuzes by burning. Although previous removal actions were performed at the Land Mine Fuze Burn Area in 1996 and 1997, additional land mine fuzes are likely to be present. More detailed information pertaining to the Land Mine Fuze Burn Area can be found in the OU 10-04 Comprehensive RI/FS (DOE-ID 2001).

\section{C-3. DESCRIPTION OF OPERATIONS AND MAINTENANCE}

\section{C-3.1 Institutional Controls}

DOE-ID will implement and maintain institutional controls at CERCLA sites at the INL where contamination precludes unrestricted use. The DOE-ID ensures that institutional controls will be in effect over the next 100 years or more, unless a 5-year review concludes that unrestricted land use is allowable and institutional controls are no longer required. Institutional controls will not be required if (a) all contaminant media are removed, (b) contamination concentrations are comparable to local background values, or (c) residual concentrations allow unrestricted use.

All institutional control requirements for OU 10-04 sites - including implementation, maintenance, inspection, monitoring, enforcement, and reporting - are addressed in the INL Sitewide Institutional Controls Plan (DOE-ID 2006). The Sitewide Institutional Controls Plan is the principal document governing establishment, implementation, enforcement, and monitoring of institutional controls at all INL Sites requiring institutional controls under CERCLA (42 USC § 9601 et seq.). The Sitewide Institutional Controls Plan was developed in accordance with the Record of Decision (ROD) requirements (DOE-ID 2002). Institutional controls for all OU 10-04 sites include a CERCLA sign, with some sites also requiring physical access restrictions.

For access to the ordnance areas and TNT/RDX-contaminated soil sites, permission from the WAG 10 remediation project manager must be obtained. Signs posted at logical points of entrance and at intervals along the perimeter of the areas identify the potential hazards, provide a point of contact, and 
stipulate that permission from the WAG 10 manager is required prior to entry. Other access controls include training and escort requirements and restrictions on land use. All personnel performing fieldwork at the INL must complete a training course on recognition of UXO, which also identifies areas at the INL with known or potential UXO. In order to conduct work within the ordnance areas and the TNT/RDX-contaminated soil sites, workers must be trained to recognize ordnance and explosives, understand the hazards, and become familiar with the reporting requirements. An excavation permit is required for any work involving land disturbance, such as drilling or excavation, which must be approved by an explosive ordnance disposal-qualified expert who is familiar with the UXO areas at the INL and will determine if a survey for UXO is required before fieldwork can commence.

\section{C-3.2 Environmental Monitoring}

Ecological monitoring is the only type of environmental monitoring to be conducted under OU 10-04 and will occur as part of the Phase I activities. In accordance with the provisions of the ROD (DOE-ID 2002), a long-term ecological monitoring plan has been implemented to ensure protection of the INL's ecosystem. Ecological monitoring is being performed in accordance with the requirements delineated in the Long-Term Ecological Monitoring Plan for the Idaho National Engineering and Environmental Laboratory (INEEL 2004). The purpose of the long-term ecological monitoring is to eliminate uncertainty in the INL-wide ecological risk assessment, allow coordination with ongoing environmental monitoring efforts, allow coordination with other agency activities, and address stakeholder concerns.

Ecological monitoring may be discontinued at any of the UXO- or TNT/RDX-contaminated sites after a 5-year review, if the Agencies determine that monitoring is no longer required. The Agencies also may change the frequency of environmental monitoring in a 5-year review. As stated in the ROD (DOE-ID 2002), OU 10-08 is responsible for groundwater monitoring; therefore, groundwater monitoring is not an activity for OU 10-04. Any postremediation monitoring required for the remediation sites will be determined once remedial action for Phases II through IV has been completed.

\section{C-3.3 Operation and Maintenance}

Five UXO-contaminated sites identified in the ROD (DOE-ID 2002) require remedial action, which will be performed in this Phase IV of the OU 10-04 remediation. Until remediation of these sites is performed, institutional controls to protect human health and the environment will be established and maintained. The institutional control requirements for the sites are addressed in the INL Sitewide Institutional Controls Plan (DOE-ID 2006). The institutional controls will remain in place until it is determined either through submittal of and concurrence with a remedial action report or during a 5-year review that they are no longer necessary. Operations and maintenance of OU 10-04 sites will be performed in accordance with the requirements of this plan, as well as those outlined in the INL Sitewide Operations and Maintenance Plan for CERCLA Response Actions (DOE-NE-ID 2006a).

\section{C-3.4 Five-Year Reviews}

In accordance with the "National Oil and Hazardous Substances Pollution Contingency Plan" (40 CFR 300) for sites where contamination is left in place above risk-based levels for unrestricted use, a review of the selected remedy will be conducted every 5 years until it is determined by the Agencies to be unnecessary. During the 5-year review, the remedy is evaluated to determine if it remains protective of human health and the environment. The review also includes an evaluation of new data that could change the monitoring or controls in place for the sites. It is the intent that a consolidated 5-year review will be performed for the four phases of the OU 10-04 remedial action as part of the Sitewide 5-year review 
conducted at the INL. The first INL Sitewide 5-year review was completed in 2005 as documented in the Five-Year Review of CERCLA Response Actions at the Idaho National Laboratory (DOE-NE-ID 2006b). The next 5-year review is scheduled for 2010. Given that the remedial actions involving the OU 10-04 sites were yet to be implemented and the OU 10-08 comprehensive ROD is yet to be written, no recommendations were provided in the 5-year review that would impact WAG 10.

\section{C-4. OPERATIONS AND MAINTENANCE IMPLEMENTATION}

This section summarizes the activities needed to implement the Phase IV O\&M requirements for OU 10-04. These activities include performing inspections, outlining the organizational practices that will drive the O\&M activities, and specifying the individuals responsible for performing the activities. As described in Section C-3, there are no planned operations or scheduled maintenance activities. However, it may be necessary to perform unscheduled maintenance and repairs if additional contamination is found.

\section{C-4.1 Organization and Responsibilities}

\section{C-4.1.1 U.S. Department of Energy Idaho Operations Office Project Manager}

The DOE-ID WAG 6/10 remediation project manager is responsible for ensuring that the O\&M activities are performed in accordance with this approved plan and overseeing the activities of the INL contractor at WAG 6, OU 6-05 and WAG 10, OU 10-04.

\section{C-4.1.2 Idaho National Laboratory Management and Operations Contractor}

As the point of contact for O\&M activities, the Idaho Cleanup Project (ICP) contractor WAG 6/10 remediation project manager will be responsible for maintaining document control of inspection reports (including placement in the project records file), administrating subcontracts for performing required activities, and reporting activities to DOE-ID.

\section{C-4.2 Conducting Monitoring, Maintenance, and Inspections}

The ICP contractor will provide qualified personnel to perform the O\&M activities for remedial actions conducted under the OU 10-04 ROD (DOE-ID 2002). Personnel will be trained on the requirements of the approved plan before performing O\&M activities. The ICP project manager is responsible for inspection implementation and reporting. Any additional UXO sites that are identified will be reported and addressed under the Phase I O\&M activities on an as-needed basis.

\section{C-4.2.1 Institutional Controls}

Institutional controls will be implemented and maintained at the UXO sites requiring remediation until remediation is complete and it is determined either through the submittal of and concurrence with a remedial action report or during a 5-year review that institutional controls are no longer required. Requirements and frequency for institutional control inspection and maintenance are addressed in the INL Sitewide Institutional Controls Plan (DOE-ID 2006). The inspections will address institutional control requirements for each site, such as identification and warning signs, visible access restrictions, administrative controls, and land-use restrictions. 


\section{C-4.2.2 Ecological Monitoring}

Long-term ecological monitoring will be conducted as prescribed in the OU 10-04 ROD (DOE-ID 2002). Details of the ecological monitoring are described in the Long-Term Ecological Monitoring Plan for the Idaho National Engineering and Environmental Laboratory (INEEL 2004).

\section{C-4.2.3 Operations and Maintenance}

No routine maintenance is planned for the UXO-contaminated sites. The only planned routine activities will involve inspections and maintenance of CERCLA signs, ordnance and explosive warning signs, and any existing physical access restrictions (e.g., fencing). Signs of unauthorized intrusion also will be monitored during site inspections. These routine activities will be performed according to the requirements delineated in the Operations and Maintenance Plan for Operable Units 6-05 and 10-04, Phase I (DOE-ID 2004b), as well as those outlined in the INL Sitewide Operations and Maintenance Plan for CERCLA Response Actions (DOE-NE-ID 2006a).

In accordance with the Operations and Maintenance Plan for Operable Units 6-05 and 10-04, Phase I (DOE-ID 2004b), surface ordnance and explosives discovered during routine INL Site operations that, based on expert evaluation, pose an unacceptable near-term physical hazard may be removed or isolated. A decision to remove, detonate in place, or isolate the identified item before remediation of sites contaminated with ordnance and explosives will be based on the determined hazard level. Any item determined to pose an unacceptable near-term physical hazard will be removed and disposed of by high-order detonation, detonated in place, or isolated and posted with signs. Such an action will not initiate full remediation of the affected area, since full remediation will be performed either under Phase III (for explosives) or Phase IV (for UXO).

\section{C-5. REPORTING REQUIREMENTS}

Reporting requirements related to institutional controls, environmental monitoring, operations and maintenance, and 5-year reviews are summarized in the following sections. The purpose of these reporting activities is to ensure that all activities are adequately documented and that related data and information are provided to the Agencies for review and decision-making. Although the following sections indicate separate reporting requirements and separate reports, the reporting requirements may be met by combining the information into a single annual report. The frequency of all the reporting identified in the following sections will be reviewed by the Agencies during the first 5-year review and may be adjusted to an alternative frequency. All reports will be submitted electronically to the INL Information Repository for records storage.

\section{C-5.1 Institutional Control Reporting}

Reporting requirements for institutional controls are specified in the INL Sitewide Institutional Controls Plan (DOE-ID 2006). An institutional control monitoring report will be prepared and submitted to the Agencies for information on an annual basis throughout the duration of the site's O\&M activities.

\section{C-5.2 Environmental Monitoring Reporting}

The only environmental monitoring to be conducted by OU 10-04 is the long-term ecological monitoring. Data and results from the ecological monitoring will be compiled and presented in an annual monitoring report. This annual report will be prepared and submitted to the Agencies for information. 


\section{C-5.3 Operations and Maintenance Reporting}

Data and results from annual inspections (e.g., information regarding site intrusions, warning signs, and physical access restrictions) will be compiled and presented in an annual report, which will be submitted to the Agencies for information. The report will contain documentation of scheduled inspections, follow-up and contingency inspections, and maintenance activities. It will include the following as a minimum:

- General OU description and operational history

- A summary of the inspection

- A summary of maintenance activities to date

- An estimate of maintenance activities required in the next year

- A copy of the appropriate inspection report forms.

\section{C-5.4 Five-Year Review Reporting}

Data and results from the annual reports for institutional controls, environmental monitoring, and O\&M will be summarized and addressed in a 5-year review report. The 5-year review report will be prepared in accordance with the requirements delineated in the Idaho National Engineering and Environmental Laboratory Sitewide Five-Year Review Plan for CERCLA Response Actions (DOE-NE-ID 2004). Additional content requirements for the report will be developed and included in future revisions of that plan.

\section{C-6. REFERENCES}

40 CFR 300, 2006, "National Oil and Hazardous Substances Pollution Contingency Plan," Code of Federal Regulations, Office of the Federal Register, October 2006.

42 USC § 9601 et seq., 1980, "Comprehensive Environmental Response, Compensation, and Liability Act of 1980 (CERCLA/Superfund)," United States Code, December 11, 1980.

DOE-ID, 1991, Federal Facility Agreement and Consent Order for the Idaho National Engineering Laboratory, Administrative Docket No. 1088-06-29-120, U.S. Department of Energy Idaho Operations Office; U.S. Environmental Protection Agency, Region 10, Idaho Department of Health and Welfare, December 4, 1991.

DOE-ID, 1998, Preliminary Scoping Track 2 Summary Report for Operable Unit 10-03 Ordnance, Volumes 1 and 2, DOE/ID-10566, Rev. 0, U.S. Department of Energy Idaho Operations Office, January 1998.

DOE-ID, 2001, Comprehensive Remedial Investigation/Feasibility Study for Waste Area Groups 6 and 10 Operable Unit 10-04, DOE/ID-10807, Rev. 0, U.S. Department of Energy Idaho Operations Office, August 2001.

DOE-ID, 2002, Record of Decision Experimental Breeder Reactor-I/Boiling Water Reactor Experiment Area and Miscellaneous Sites, Operable Units 6-05 and 10-04, DOE/ID-10980, Rev. 0, U.S. Department of Energy Idaho Operations Office; U.S. Environmental Protection Agency, Region 10; Idaho Department of Environmental Quality, November 2002. 
DOE-ID, 2003, Operable Units 6-05 and 10-04, Experimental Breeder Reactor-I/Boiling Water Reactor Experiment Area and Miscellaneous Sites, Remedial Design/Remedial Action Scope of Work, DOE/ID-11035, Rev. 0, U.S. Department of Energy Idaho Operations Office, February 2003.

DOE-ID, 2004a, Remedial Design/Remedial Action Work Plan for Operable Units 6-05 and 10-04, Phase I, DOE/ID-11101, Rev. 0, U.S. Department of Energy Idaho Operations Office, February 2004.

DOE-ID, 2004b, Operations and Maintenance Plan for Operable Units 6-05 and 10-04, Phase I, DOE/ID-11102, Rev. 1, U.S. Department of Energy Idaho Operations Office, February 2004.

DOE-ID, 2006, INL Sitewide Institutional Controls Plan, DOE/ID-11042, Rev. 3, U.S. Department of Energy Idaho Operations Office, July 2006.

DOE-NE-ID, 2004, Idaho National Engineering and Environmental Laboratory Sitewide Five-Year Review Plan for CERCLA Response Actions, DOE/NE-ID-11125, Rev. 2, U.S. Department of Energy Idaho Operations Office, September 2004.

DOE-NE-ID, 2006a, INL Sitewide Operations and Maintenance Plan for CERCLA Response Actions, DOE/NE-ID-11159, Rev. 1, U.S. Department of Energy Idaho Operations Office, May 2006.

DOE-NE-ID, 2006b, Five-Year Review of CERCLA Response Actions at the Idaho National Laboratory, DOE/NE-ID-11201, Rev. 1, U.S. Department of Energy Idaho Operations Office, June 2006.

INEEL, 2004, Long-Term Ecological Monitoring Plan for the Idaho National Engineering and Environmental Laboratory, INEEL/EXT-02-01191, Rev. 1, Idaho Completion Project, Idaho National Engineering and Environmental Laboratory, January 2004. 
Appendix D

\section{Cultural Resources Summary}


D-2 


\section{Appendix D}

\section{Cultural Resources Summary \\ A Summary of Archaeological Surveys Completed in Advance of Ordnance Identification and Remediation 1986-1997}

\section{D-1. INTRODUCTION}

In 1942, a portion of what is now designated as the Idaho National Laboratory (INL) was set aside by the U.S. Navy to test fire naval guns, to conduct mass detonation tests, to practice aerial bombing, and to perform explosive material compatibility tests. As a result of these activities, many projectiles (explosive and inert) and explosive residues remain within the current boundaries of the INL. Efforts to characterize and remediate the areas affected by these activities are ongoing. Since some remedial actions have the potential to disturb the ground, archaeological surveys have been completed in advance of most cleanup efforts.

\section{D-2. SUMMARY}

A subcontractor from Idaho State University completed the first ordnance-related archaeological survey on the INL in 1986. At this time, the perimeter of the Naval Ordnance Disposal Area (NODA), an area now known as the NODA racetrack, was intensively examined. No archaeological resources were identified (Reed 1986). No additional ordnance-related archaeological surveys were completed until the 1990s, when characterization and cleanup were accelerated. Six archaeological surveys were completed from 1992-1997, all in advance of characterization and remediation at a variety of areas. Since 1997, cleanup activities have been restricted to areas that have been previously surveyed for archaeological resources. As a result of these efforts, some level of archaeological survey coverage has been achieved for the following locations:

- $\quad$ Areas surrounding the NODA

- Central Facilities Area (CFA) gravel pit and landfill complex

- Vicinity of the CFA-633 building

- $\quad$ Storage bunkers north of the Idaho Nuclear Technology and Engineering Center (INTEC)

- A small area east of the Reactor Technology Complex (RTC) (formerly the Test Reactor Area)

- Areas surrounding the National Oceanic and Atmospheric Administration (NOAA) facility

- $\quad$ Areas surrounding the now-demolished INL Fire Station II

- A narrow zone on either side of a 10-mi stretch of power line extending north from Antelope substation

- $\quad$ Area south of the Materials and Fuels Complex (MFC) (formerly Argonne National Laboratory-West)

- $\quad$ Spot near Milepost 17 on Lincoln Boulevard

- $\quad$ Areas surrounding the Experimental Field Station 
- $\quad$ Craters east of INTEC

- Areas surrounding the Mass Detonation Area

- Areas surrounding the Railcar Explosion Area

- $\quad$ Areas surrounding the Land Mine Fuse Burn Area.

Formal and informal reports for these surveys are included in the INL cultural resource management (CRM) files (Pace 1996, 1997; Ringe 1992, 1993, 1994) along with letters of concurrence from the Idaho State Historic Preservation Office for some projects (i.e., 1992, 1993, 1994, and 1996). Although they were invited to provide their views in 1997, the Shoshone-Bannock Tribes have not responded.

Archaeological resources have been identified in many of the ordnance areas. Table D-1 below summarizes these findings. Note: Italicized ordnance areas are under consideration for future cleanup and remediation.

Table D-1. Archaeological resource summaries.

\begin{tabular}{|c|c|c|}
\hline Ordnance Area & $\begin{array}{c}\text { Total Number of } \\
\text { Archaeological Resources } \\
\text { in Ordnance Area }\end{array}$ & $\begin{array}{c}\text { Total Number of Significant } \\
\text { Archaeological Resources in } \\
\text { Ordnance Area }\end{array}$ \\
\hline$N O D A$ & Twelve & $\begin{array}{l}\text { Nine: } \\
\text { - } 10-B T-808 / 94-N O D A-4 \\
\text { - } 10-B T-809 \\
\text { - } 10-B T-812 \\
\text { - } 10-B T-813 \\
\text { - } 10-B T-814 \\
\text { - } 94-N O D A-3 \\
\text { - LMIT-97-21-13 } \\
\text { - LMIT-97-21-14 }\end{array}$ \\
\hline $\begin{array}{l}\text { CFA gravel pit and landfill } \\
\text { complex }\end{array}$ & None & None \\
\hline $\begin{array}{l}\text { Vicinity of the CFA- } 633 \\
\text { building }\end{array}$ & None & $\begin{array}{l}\text { None (The CFA- } 633 \text { building is } \\
\text { designated as a historic building.) }\end{array}$ \\
\hline $\begin{array}{l}\text { Storage bunkers north of } \\
\text { INTEC }\end{array}$ & None & None \\
\hline Area east of RTC & One & None \\
\hline$N O A A$ facility & Five & $\begin{array}{l}\text { Two: } \\
\text { - LMIT-97-21-5 } \\
\text { - LMIT-97-21-6 }\end{array}$ \\
\hline Fire Station II & Four & 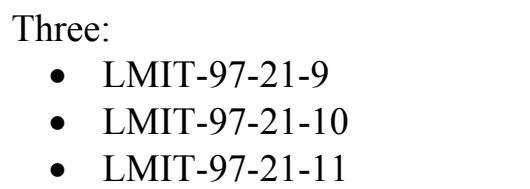 \\
\hline
\end{tabular}


Table D-1. (continued).

\begin{tabular}{|c|c|c|}
\hline Ordnance Area & $\begin{array}{c}\text { Total Number of } \\
\text { Archaeological Resources } \\
\text { in Ordnance Area }\end{array}$ & $\begin{array}{c}\text { Total Number of Significant } \\
\text { Archaeological Resources in } \\
\text { Ordnance Area }\end{array}$ \\
\hline $\begin{array}{l}\text { Power line extending north } \\
\text { from Antelope substation }\end{array}$ & Nineteen & $\begin{array}{cl}\text { Ten: } & \\
\text { - } & \text { EGG-93-ORD-2 } \\
\text { - } & \text { EGG-93-ORD-3 } \\
\text { - } & \text { EGG-93-ORD-6 } \\
\text { - } & \text { EGG-93-ORD-7 } \\
\text { - } & \text { EGG-93-ORD-9 } \\
\text { - } & \text { EGG-93-ORD-10 } \\
\text { - } & \text { EGG-93-ORD-14 } \\
\text { - } & \text { EGG-93-ORD-19 } \\
\text { - } & \text { EGG-93-ORD-20 }\end{array}$ \\
\hline MFC & Six & $\begin{array}{l}\text { One: } \\
\text { • } 94-A N L W-5\end{array}$ \\
\hline Milepost 17 on Lincoln Blvd. & None & None \\
\hline Experimental Field Station & None & None \\
\hline Craters east of INTEC & None & None \\
\hline Mass Detonation Area & None & None \\
\hline Railcar Explosion Area & Four & $\begin{array}{l}\text { Four: } \\
\text { - LMIT-96-51-4 } \\
\text { - LMIT-96-51-5 } \\
\text { - LMIT-96-51-6 } \\
\text { - LMIT-96-51-7 }\end{array}$ \\
\hline Land Mine Fuze Burn Area & Two & $\begin{array}{l}\text { One: } \\
\text { - LMIT-96-51-3 } \\
\text { - One unrecorded site nearby }\end{array}$ \\
\hline \multicolumn{3}{|c|}{$\begin{array}{l}\text { CFA = Central Facilities Area } \\
\text { INTEC = Idaho Nuclear Technology and Engineering Center } \\
\text { MFC = Materials and Fuels Complex } \\
\text { NOAA = National Oceanic and Atmospheric Administration } \\
\text { NODA = Naval Ordnance Disposal Area } \\
\text { RTC = Reactor Technology Complex }\end{array}$} \\
\hline
\end{tabular}

As a general rule, consultation with the State Historic Preservation Office on past cleanup efforts has resulted in the implementation of the following recommendations to protect the significant archaeological resources during ordnance identification and remediation:

- All contractor and subcontractor personnel who will enter the ordnance removal area will attend an archaeological resource protection training session offered by the INL CRM Office.

- $\quad$ All access to and from the ordnance removal areas will be restricted to existing roads and tracks. Off-road vehicle travel is approved within the boundaries of the surveyed areas, but it is not approved within the boundaries of any identified cultural resource site areas. 
- If safety considerations allow, all ordnance devices will be removed from identified cultural resource site areas before detonation.

- In the event that an ordnance device cannot be safely removed from a cultural resource site area, a member of the INL CRM Office will be present during or immediately after the disposal process to immediately assess any impacts and stabilize any cultural materials that may be exposed.

- $\quad$ All work will be redirected and the INL CRM Office will be consulted immediately if any unusual materials (e.g., bones, charcoal-stained soil, rock alignments, obsidian flakes, pottery, stone tools) are unexpectedly encountered, particularly during subsurface activities.

- $\quad$ Efforts will be made to continue to offer invitations to the Shoshone-Bannock Tribes cultural resources coordinator to become involved in monitoring, surveying, and other project activities.

Proposed future cleanup and remediation at the Fire Station II, Experimental Field Station, Land Mine Fuse Burn, NOAA, and NODA areas have the potential to impact at least 14 significant archaeological sites. The recommendations summarized above in regard to worker education, archaeological monitoring, stop work, and tribal involvement should be implemented for the work. In addition, archaeological survey should be expanded as necessary to encompass all of the lands that might require remediation. Under present plans, it appears that the following portions of these areas remain unsurveyed:

- $\quad 4$ acres on north end of Fire Station II

- 1 acre on southeastern end of Experimental Field Station

- 20 acres north of the Big Lost River at NODA.

Archaeological surveys must be completed in the above areas to fully assess the effects of the proposed cleanup and remediation.

\section{D-3. REFERENCES (ANNOTATED) CITED}

Pace, Brenda Ringe, 1996, “Archaeological Surveys for 1996 Ordnance Removal Actions,” Internal Report No. LMIT-96-51, November 1996.

- $\quad$ The report presents documentation of intensive archaeological survey of a 20-acre cleanup area at the Railcar Explosion Area, a 27-acre area at the Land Mine/Fuse Burn Area, and a 10-acre area east of TRA (now called the Reactor Technology Complex). Seven archaeological resources are identified, five potentially eligible for nomination to the National Register of Historic Places and recommended for protection (four at Railcar Area, one at Fuse Burn Area). Standard recommendations include removal of ordnance devices for detonation whenever possible in sensitive areas, archaeological monitoring/salvage after in-place detonation and sampling, and worker education in archaeological protection. Recommendations to limit off-road vehicle use also are included. Idaho State Historic Preservation Office concurrence is noted (R. M. Yohe to Brenda Ringe Pace, "Archaeological Reports, LMIT-95-6, Ordnance Cleanup Project,"

November 19, 1996). 
Pace, Brenda Ringe, 1997, “Archaeological Surveys for 1997 Ordnance Removal Actions,” Internal Report No. LMIT-97-21.

- Report presents documentation of intensive archaeological survey of a 2-acre area at the Experimental Field Station, a 13-acre area at the Fire Station II area, a 32-acre area at the Railcar Explosion Area, a 74-acre area at the Mass Detonation Area, a 33-acre area at the National Oceanic and Atmospheric Administration area, a 112-acre area at the Naval Ordnance Disposal Area, and a 15-acre area of craters east of INTEC. Four previously recorded archaeological resources are identified and 15 new archaeological resources are identified, 10 potentially eligible for nomination to the National Register of Historic Places (two at Fire Station II, two at NOAA, six at NODA). Standard recommendations included removal of ordnance devices for detonation whenever possible in sensitive areas, archaeological monitoring/salvage after in-place detonation and sampling, and worker education in archaeological protection. Recommendations to limit off-road vehicle use also are included.

Reed, W. G., 1986, “An Archaeological Survey of the Naval Ordnance Disposal Area of the Idaho National Engineering Laboratory," Swanson/Crabtree Anthropological Research Laboratory Reports of Investigations: $86-17$.

- This report presents documentation of intensive archaeological survey of the NODA "racetrack" by a subcontractor from Idaho State University. No archaeological resources are identified.

Ringe, Brenda L., 1992, Letter to M. W. Lusk, January 23, 1992, "Archaeological Considerations in the Removal of Unexploded Ordnance from the INEL," BLR-05-92, INEEL Cultural Resource Management Archives.

- This document represents a clearance recommendation for cleanup of surface ordnance at miscellaneous locations, including CFA gravel pit/landfill complex, CFA-633, NOAA, an area east of RTC, Fire Station II, and at storage bunkers near INTEC. It includes recommendation for archaeological survey of power line extending north of Antelope Substation before cleanup activities. Archaeological surveys are recommended in areas not previously examined (power line) and in any future proposed cleanup areas (aerial bombing ranges near the Radioactive Waste Management Complex and MFC, firing fan between the Naval Ordnance Training Facility and Big Southern Butte). Cleanup in archaeologically sensitive areas is recommended for archaeological monitoring and post-cleanup salvage. Worker education in archaeological protection also is recommended. Idaho State Historic Preservation Office concurrence is noted (T. Green to A. Williams, "Unexploded Ordnance Interim Action Cultural Resources Assessment, INEL," April 7, 1992).

Ringe, Brenda L., 1993, "Archaeological Surveys for the Idaho National Engineering Laboratory Ordnance Cleanup,” External Report No. EGG-CS-10995.

- $\quad$ Report presents documentation of intensive archaeological survey of 11-mi-long power line corridor in advance of ordnance cleanup. Nineteen archaeological resources are identified, 10 potentially eligible for nomination to the National Register of Historic Places and recommended for protection. Recommendations include removal of ordnance devices for detonation whenever possible in sensitive areas, archaeological monitoring/salvage after in-place detonation and sampling, and worker education in archaeological protection. Idaho State Historic Preservation Office concurrence is noted (R. M. Yohe to B. L. Ringe, "EGG-93-7, INEL Sitewide Ordnance Cleanup," June 25, 1993). 
Ringe, Brenda L., 1994, "Archaeological Surveys for Ordnance Remediation at ANL-W and the NODA on the INEL," External Report No. EGG-CS-11319.

- $\quad$ Report presents documentation of intensive archaeological survey of 40-acre area surrounding NODA racetrack, 90-acre area south of MFC, and small location near Milepost 17 along Lincoln Boulevard. Ten archaeological resources are identified, four potentially eligible for nomination to the National Register of Historic Places and recommended for protection (three at NODA, one at MFC). Standard recommendations included removal of ordnance devices for detonation whenever possible in sensitive areas, archaeological monitoring/salvage after in-place detonation and sampling, and worker education in archaeological protection. Idaho State Historic Preservation Office concurrence on eligibility is noted (R. M. Yohe to B. L. Ringe, Cultural Resource Draft Report BLR-19-94, Argonne National Laboratory-West, Naval Ordnance Disposal Area, July 5, 1994). 